\title{
Fungal cell wall disruption by alkamides from Echinacea
}

\author{
By \\ Isabel Maria Linhares Cruz, B.Sc. \\ A thesis submitted to \\ The Faculty of Graduate Studies and Research \\ in partial fulfilment of the degree requirements of \\ (Master of Science)
}

\author{
Department of Biology \\ Carleton University \\ Ottawa, Ontario, Canada \\ (August 2011)
}

Copyright (C)

2011 - Isabel Cruz 
Library and Archives

Canada

Published Heritage Branch

395 Wellington Street Ottawa ON K1A ON4 Canada
Bibliothèque et

Archives Canada

Direction du

Patrimoine de l'édition

395 , rue Wellington

Ottawa ON K1A ON4

Canada
Yourfile Votre référence

ISBN: 978-0-494-83172-4

Our file Notre référence

ISBN: 978-0-494-83172-4
NOTICE:

The author has granted a nonexclusive license allowing Library and Archives Canada to reproduce, publish, archive, preserve, conserve, communicate to the public by telecommunication or on the Internet, loan, distribute and sell theses worldwide, for commercial or noncommercial purposes, in microform, paper, electronic and/or any other formats.

The author retains copyright ownership and moral rights in this thesis. Neither the thesis nor substantial extracts from it may be printed or otherwise reproduced without the author's permission.

\section{AVIS:}

L'auteur a accordé une licence non exclusive permettant à la Bibliothèque et Archives Canada de reproduire, publier, archiver, sauvegarder, conserver, transmettre au public par télécommunication ou par l'Internet, prêter, distribuer et vendre des thèses partout dans le monde, à des fins commerciales ou autres, sur support microforme, papier, électronique et/ou autres formats.

L'auteur conserve la propriété du droit d'auteur et des droits moraux qui protège cette thèse. $\mathrm{Ni}$ la thèse ni des extraits substantiels de celle-ci ne doivent être imprimés ou autrement reproduits sans son autorisation.
In compliance with the Canadian Privacy Act some supporting forms may have been removed from this thesis.

While these forms may be included in the document page count, their removal does not represent any loss of content from the thesis.
Conformément à la loi canadienne sur la protection de la vie privée, quelques formulaires secondaires ont été enlevés de cette thèse.

Bien que ces formulaires aient inclus dans la pagination, il n'y aura aucun contenu manquant. 
"The important thing is not to stop questioning. Curiosity has its own reason for existing. One cannot help but be in awe when he contemplates the mysteries of eternity, of life, of the marvelous structure of reality. It is enough if one tries merely to comprehend a little of this mystery every day."

Albert Einstein-From the memoirs of William Miller, an editor, quoted in Life magazine, May 2, 1955; Expanded, p. 281. 


\section{Abstract}

The research presented in this thesis focuses on the study of the antifungal properties, mode of action and molecular structure-antifungal activity relationship of selected alkamides.

Echinacea's antimicrobial and antioxidant activities, and its ability to modulate the immune cells activity have been demonstrated in several studies. The phytochemical composition of Echinacea is well established as a complex mix of caffeic acid derivatives, glycoproteins, polysaccharides and the lipophilic alkamides. The complexity of the extract composition makes it difficult to determine if the pharmacological effects of Echinacea preparations are caused by a specific compound, a class of compounds or are the result of the many constituents acting synergistically. However, new insights concerning the membrane permeability, bioavailability and molecular mode of action, have renewed interest in the hypothesis that alkamides are implicated in the pharmacological effects of Echinacea. Alkamides are secondary metabolites widely distributed in plants and the major lipophilic compounds in Echinacea extracts. This large group of closely related unsaturated fatty acid amides are mostly derived from undeca and dodecanoic acids that differ by the length of the carbon chain, the degree of saturation, and position of saturated carbon bonds. Here I propose to test the hypothesis that the antifungal mode of action of Echinacea extracts is through the disruption of the yeast cell wall/membrane complex by alkamides. 


\section{Dedication}

\section{In memoriam}

This dissertation is dedicated to my mother Maria José Linhares Cruz, to my little sisters Artemara and Idjanira, and to a never born sibling I didn't have the chance to get to know. I'm grateful for the few years I shared their presence in this realm. I miss you!

This dissertation is especially dedicated to my father José Artero Cruz, whose life was cut short by heart disease. As a little girl he stilled in me the confidence to live my dreams, such as this one. His absence is deeply felt at this moment of accomplishment in my life.

Dad was the best example of generosity, dignity, simplicity and honesty I ever knew. In truth, everything I know that matters in life I learned from him - A man of few but very wise words. Unfortunately, the ability to listen carefully and to say just the essential is one thing I didn't take from my father. And I could have used it in some occasions! I am the most fortunate to have been my "dad's little girl" and to have had him as role model.

\section{Dedicatória}

\section{In memoriam}

Esta dissertação é dedicada a minha mãe Maria Jose Linhares Cruz, às minhas irmazinhãs Artemara e Idjanira e ao irmão/irmã que não chegou a nascer $e$ que não tive a oportunidade de conhecer. Sou grata pelos poucos anos que passamos juntos nesta realidade. Saudades!

Esta dissertação é especialment dedicada ao meu pai José Artero Cruz, cuja vida foi encurtada por doença cardíaca. Quando menina ele infundiu em mim a confiança necessária para realizar os meus sonhos., como este aqui. Sua ausência é profundamente sentida neste momento de realização in minha vida.

Meu pai foi o melhor exemplo de generosidade, dignidade, simplicidade and honestidade que conheci. Na verdade, tudo o que aprendi de importante na yida aprendi com meu pai-Um homem de poucas mas sábias palavras. Infelizmente, dele eu não herdei a qualidade de ouvir atentamente $e$ falar apenas o necessário, o que às vezes me faz falta! Me considero uma pessoa de sorte por ter sido sua filha querida e por tê-lo tido como exemplo de vida. 
To the Sunshines of My Life

Motherhood is one of the most rich and profound experiences in a woman's life.

I dedicate this dissertation to my beautiful and beloved children, Flavio Daniel Cruz Caracas and Gabriela Cruz Caracas. I am so proud to be your mother, I love you two dearly!

This thesis is also dedicated to my lifelong partner, husband, the love of my life, and above all my very best friend Flávio Caracas Jr. Thank you for being my partner in all the ups and downs and ins and outs of life including this project. This thesis is also yours, because without your patience, understanding and endless love throughout this entire process this work would probably have not even started. You put up with a lot without ever questioning the wisdom of my dream of getting my Master's degree. And finally, I want to tell you how sorry I am that travelling and weekends have been put on hold for the last few years of our lives so I could achieve this goal in my academic pursuits. I promise that eventually, you will get your sailing boat; a canoe is still a boat right?
Aos Raios de Sol da Minha Vida

Ser mãe é uma das experiências mais profundas e ricas da vida de uma mulher. Dedico esta dissertação aos meus lindos e queridos filho e filha, Flavio Daniel Cruz Caracas and Gabriela Cruz Caracas. Eu sou uma mãe tão orgulhosa, amo vocês dois imensamente!

Esta tese também é dedicada ao meu companheiro, esposo, amor da minha vida, e sobretudo meu melhor amigo, Flávio Caracas Jr. Obrigada por ser meu parceiro em todos os altos e baixos $e$ todos os "sobe-e-desce" da vida incluindo este projeto. Esta tese é sua também porque sem a sua paciencia, compreensão e infinita afeição, durante todo este processo, este projeto não teria nem começado. Você aturou muito sem nunca questionar a sensatez do meu sonho de fazer meu mestrado. E finalmente, quero the pedir desculpas pela vida dos últimos anos, quando viagens e finais de semana foram sacrificados para que eu pudesse realizar mais uma conquista em minha formação acadêmica. Prometo que, eventualmente, você terá seu barco, afinal canoa conta como barco, não conta? 


\section{Acknowledgements}

It is with immense gratitude that I thank

Dr. Myron Smith for the opportunity to pursue my Master's degree under his supervision and to draw upon his vast knowledge and experience.

Besides his constant good nature and seemingly endless patience, one of Myron's best attributes, is his ability to motivate and offer sound advice in times of confusion, when experiments don't go smoothly and frustration mounts; which happens more often than not. His broad knowledge, positive feedback and constructive criticism has guided my research through many challenges and difficulties, and yet I was always treated as an equal. Myron's open door policy impressed me. I always felt welcomed at any time, a knock on his door was all I needed to have a chat with him and he was always happy and willing to give advice on how to troubleshoot an experiment or on what to do next; and for that I am very grateful. Most importantly, by giving me the freedom to work on several

\section{Agradecimentos}

É com imensa gratidão que agradeço Dr. Myron smith pela oportunidade de realizar o meu mestrado sob a sua supervisão e de me beneficiar de seu vasto conhecimento e experiência.

Além de seu constante bom caráter e sua aparentemente infinita paciência, uma das melhores qualidades de Myron, é a sua habilidade de motivar e orientar em momentos críticos quando experimentos não dão o resultado esperado e a frustração se acumula; o que acontece com mais frequência do que se imagina. Seu vasto conhecimento, comentários positivos e criticas construtivas guiaram a minha pesquisa através de muitos desafios e dificuldades, e mesmo assim eu sempre fui tratada como igual. Muito me impressionou a politica de portas abertas de Myron. Eu sempre me senti bem vinda a qualquer hora, bater na sua porta era o suficiente para ser recebida por ele para uma conversa, sempre com muito prazer e sempre disposto a ajudar com experimentos problemáticos, aconselhando sobre qual seria o próximo passo; e por isso eu sou muito grata. E mais importante ainda, por ter me dado a liberdade 
projects outside of the main focus of my thesis, Myron has provided me with learning experiences and academic skills that extended beyond this project and highly enriched my graduate experience. Words are insufficient to express my gratefulness and indebtedness to Dr. Myron Smith for providing ideas, inspiration and the necessary support to make this research possible. One simply could not wish for a more knowledgeable or kinder supervisor.

I would like to extend my heartfelt thanks to Dr. John Thor Arnason and Dr. Peter H. Buist for accepting to be a part of my thesis committee. I want also to thank Dr. Byron Johnson for sharing his yeast cytology and microscopy expertise with me. Their invaluable guidance has helped to shape this research and their inputs have pushed my work to a much higher level.

I want to thank Dr. Lehmann from the MediHerb Research Laboratories, Queensland, Australia for supplying the synthetic alkamides used in my thesis and Dr. Jayne Yack for allowing me to de trabalhar em vários projectos fora do enfoque principal da minha tese, Myron me proporcionou adquirir experiências em aprendizagem e habilidades acadêmicas que se estendem muito além deste projecto e que muito enriqueceram minha experiência de pós-graduação. Palavras não são suficientes para expressar o meu reconhecimento e divida de gratidão com Dr. Myron Smith pelas suas idéias, inspiração e o apoio necessário para que esta pesquisa fosse possivel. Simplesmente não se pode desejar um orientador com mais conhecimento científico ou mais bondoso.

Eu gostaria de estender meus sinceros agradecimentos ao Dr. John Thor Arnason e ao Dr. Peter H. Buist por terem aceitado participar da banca examinadora. Também quero agradecer ao Dr. Byron Johnson por compartilhar comigo a sua vasta experiência em citologia e microscopia de leveduras. Suas orientações foram inestimávels e muito ajudaram a dar forma a esta pesquisa, suas sugestões $e$ contribuições enriqueceram e impulsionaram meu trabalho à um nivel mais elevado.

Quero agradecer Dr. Johnson Dr. Lehmann do MediHerb Research Laboratories, Queensland, Austrália, por 
use her Axio Imager microscope for my fluorescence microscopy experiments. Without the generosity of either one of them this work would not have been possible.

Over my years in the Smith lab, I have overlapped with a number of exceptional individuals: Melisa Begin, Kristin Duval, Fuad Tanha, Mojgan Siahbazi, Rob Smith, Denis Lafontaine, Adam Densmore, Stayce Lee-Jenkins, Hannah Mirrashed, Jeffrey Graham and Imelda Galvan Màrquez, all of whom have helped me in one way or another, either to improve academically or by challenging me to become a better person. My fellow grad students, have been a constant source of humor, companionship and support. One thing we all were very good was at listening to each other venting about "someone" using/taking our equipment/solutions without permission... Thank you for so many years of laughs. I expect them all to succeed and I wish them the best of luck. prover os alkamides sintéticos usados na minha tese e também agradeço Dra. Jayne Yack por permitir o uso do seu microscópio Axio Imager em meus experimentos com microscopia de fluorescência. Sem a generosidade de qualquer uma deles este trabalho não teria sido possível.

Minha passagem no Smith lab, coincidiu com a passagem de um número de pessoas excepcionais: Melisa Begin, Kristin Duval, Fuad Tanha, Mojgan Siahbazi, Rob Smith, Denis Lafontaine, Adam Densmore, Stayce Lee-Jenkins, Hannah Mirrashed, Jeffrey Graham and Imelda Galvan Màrquez. Todos eles me ajudaram de uma forma ou de outra, quer fosse contribuíndo para meu aperfeiçoamento acadêmico ou como um desafio para que eu me tornasse uma pessoa melhor. Meus colegas de pós-graduação, têm sido uma constante fonte de humor, companheirismo e apoio. Quando precisávamos desabafar sobre "alguém" ter usado/tomado emprestado nossos equipamentos/soluções químicas, erámos todo ouvidos. Obrigada por todos estes anos de bom humor... Eu tenho certeza que todos eles serão bem-sucedidos e desejo-lhes muita boa sorte. 
Acknowledgements

I would like to express special thanks to some colleagues: I owe a huge debt of gratitude to Melissa Begin, exceptional research assistant, whom helped me to bring my laboratory skills up to speed when I first came to the Smith lab. Always willing to help, listen and teach, Melissa it was a privilege to work with you. I am also grateful to JinQin Mao and Jose Antonio Guerrero, from Dr. Arnason's laboratory at Ottawa University for their help with the Echinacea extractions and HPLC profiles. Their contribution allowed for important data to be incorporated into this project that would not have been possible otherwise.

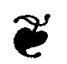

I truly believe that our minds are like antique mosaics, exquisite and complex, made out of tiny little colorful tiles, each tile is an impression left by someone that crossed our path. Each one unique in its own way.

Having this in mind, I would like to start by paraphrasing an old song "To sir, with love", which goes like this: "But how do you thank someone who has taken you
Gostaria de expressar especial gratitude a alguns colegas: Eu tenho uma enorme divida de gratidão com Melissa Begin, uma assistante de pesquisa brilhante, que ajudou-me a restabelecer e atualizar a minha capacitação laboratorial logo que começei no Smith lab. Sempre disposta a ajudar, ouvir e ensinar, Melissa foi um privilégio trabalhar com você. Eu também sou grata a Jin Qin Mao e Jose Antonio Guerrero, ambos do laboratório do Dr. Arnason na Universidade de Ottawa, pelo sua ajuda com Echinacea extractions and HPLC profiles. Suas contribuções permitiram que dados importantes fossem integrados neste projeto, o que do contrário não teria sido possivel.

$E u$ acredito que nossas mentes dsão como mosaicos antigos, extraordinários e complexos, feitos de caquinhos coloridos muito pequenos, cada um sendo uma impressão deixada por alguém que cruzou o nosso caminho. Cada um original em sua própria maneira de ser.

Com isto em mente gostaria de começar parafraseando uma canção antiga "To sir, with love" que diz: "Mas como você agradece a alguém 
from crayons to perfumes?" I would say instead: But how do you thank everyone who has taken you from crayons to the 3 times table (Auntie Nazaré Barros da Silva); from the romance and poetry of the Brazilian literature to the Universal literature (Mrs. Sônia Alelaf and Mr. Alcenor Candeira Filho-Noba); from the history of the Roman Empire and French Revolution to the Cold War (Mrs. Mirian Castelo Branco); from Newton's laws of motion to the wave nature of light (Eng. João Ernesto Araripe); from the cell biology and human genetics to the theory of evolution (Dr. Valdir Edson Soares); from human biochemistry to molecular biology, fungal genetics and beyond (Dr. Dulcinéia Abdalla and Dr. Myron Smith)? It is not easy but I'll try.

Here, to all my mentors with love: Thank you for adding such bright and colorful tiles to the mosaic of my mind. I believe each one of them was used in one way or the other in the making of this thesis.

I'm especially gratefully to my biology teacher Dr. Valdir Edson Soares, a medical doctor who would take time que te guiou dos lápis-de-cores aos perfumes?" No meu caso eu diria: Mas como você agradece a todos que the guiaram dos lápis-de-cores a tabuada de 3 (Tia Nazaré Barros da Silva); do romance e poesia da literatura brasileira à literature universal (Prof.a Sônia Alelafe Prof. Alcenor Candeira Filho-Noba); da história do Império Romano e Revolução Francesa à Guerra Fria (Prof.a Dona Mirian Castelo Branco); das 3 leis de Newton à natureza ondulatória da luz (Prof. João Ernesto Araripe); da biologia celular à genética humana e teoria da evolução (Dr. Valdir Edson Soares); da bioquímica humana à biologia molecular, genética de fungos e além (Dra. Dulcinéia Abdalla and Dr. Myron Smith)? Não é fácil, mas tentarei.

A todos os meus mentores com carinho: Muito obrigada por terem contribuído com ladrilhos tão luminosos e coloridos para o mosaico da minha mente. Penso que cada um deles foi usado de uma forma ou de outra durante a realização desta tese.

Sou especialmente grata ao meu professor de biologia Dr. Valdir Edson Soares, um médico extremamente 
from his busy life to teach biology to high school teenagers. Dr. Valdir was a good friend of my Dad who took me under his wing and instigated my inquisitive mind. In my second year of high school Dr. Valdir lent me a Portuguese translated copy of Darwin's 1859 classic "On the Origin of Species". I remember having such a hard time reading and making sense of Darwin's words, but Dr. Valdir was patient and didn't mind discussing Darwin's ideas with me and answering any questions I had. In the end the book stroke a chord with me and as they say, the rest is history. Sadly, he passed away a couple of years ago before we could meet again, and before I had the chance to say my thanks and to "brag about" my two editions of Darwin's classic in the original language, one of them nicely illustrated-So much easier to read today!

I also want to thank my family back in Brazil for their support. My brothers Artero Júnior and Ótavio Alencar Cruz, my step-mother, Maria Alencar Cruz and extended family, I love you all. They ocupado que apesar de tudo conseguia achar tempo para ensinar biologia para adolescentes cursando o científico. Dr. Valdir era amigo de meu pai, acho que por isso me tomou sob sua proteção e procurou instigar a minha mente inquisitiva. No segundo ano cientifico Dr. Valdir me emprestou uma copia traduzida para o português da famosa obra de Darwin "Sobre a origem das espécies" (1859). Foi uma leitura dificil, e fazer sentido das palavras de Darwin foi complicado, mas Dr. Valdir tinha paciência para conversar comigo e tirar minhas dúvidas sobre as idéias de Darwin. A verdade é que o livro me influenciou muito e como se diz, o resto é história. Infelizmente Dr. Valdir faleceu há alguns anos atrás antes que eu pudesse revê-lo, agradecêlo pessoalmente e "me gabar" das minhas duas edições do clássico de Darwin na língua de origem, uma delas belamente ilustrada-Tão mais fácil de ler hoje!

Agradeço também o apoio da minha familia querida no Brasil. Meus irmãos Artero Júnior e Ótavio Alencar Cruz, minha madrasta, Maria Alencar Cruz, 
don't know exactly what it is that I do; however, they are always cheering for me, and that is all that matters.

And finally, all my friends, none mentioned here and none forgotten in my heart, I do hope we find more time for each other soon. Thank you for being so kind to always ask about my research, your support meant a lot to me! e o resto da tropa, que tanto amo. Eles não sabem exatamente o que eu faço, no entanto estão sempre torcendo por mim, e isso é o que importa.

E finalmente, todos os meus amigos $e$ amigas; nenhum mencionado aqui, nenhum esquecido no meu coração; eu espero que em breve tenhamos mais tempo para passar juntos. Obrigada por sempre terem sido tão gentils e indagar sobre a minha pesquisa, o apoio de vocês foi muito importante para mim! 


\section{Table of contents}

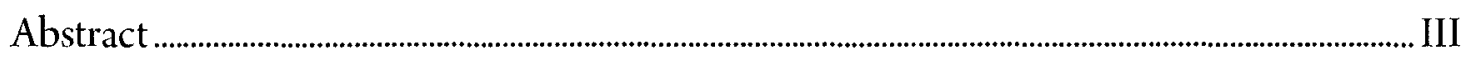

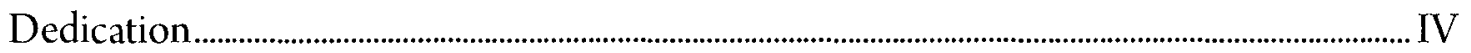

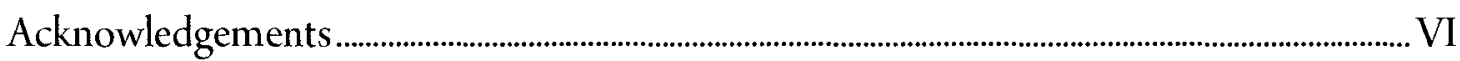

Table of contents

List of Tables .................................................................................................................................................................XVIII

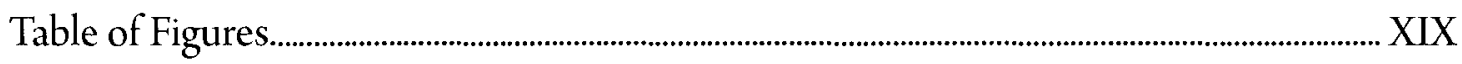

List of Abbreviation s.................................................................................................................................................XXI

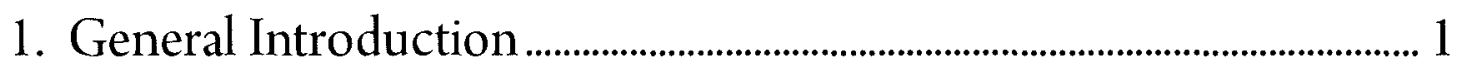

1.1. A need for new antimicrobials ........................................................................................................

1.2. Current antimicrobial research .............................................................................................6

1.2.1. Bio-prospecting for new antifungals ......................................................................................................... 6

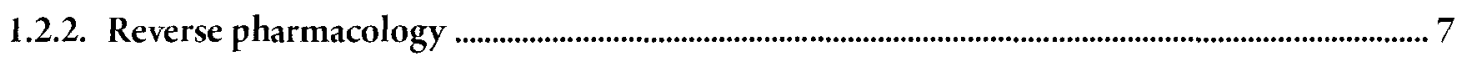

1.2.3. Finding biological active compounds in nature ............................................................................... 9

1.3. Selective cytotoxicity and the yeast cell wall.......................................................................... 11

1.4. A unique antifungal target - The fungal cell wall.................................................................11

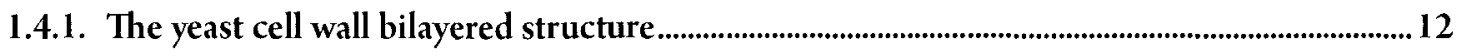

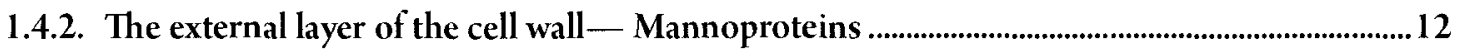

1.4.3. The inner layer of the cell wall $-\beta$-glucans.........................................................................................13 


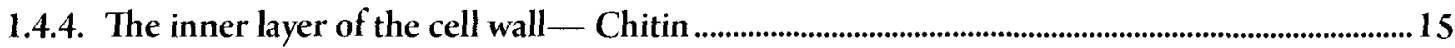

1.4.5. The cell wall regulatory apparatus .............................................................................................. 15

1.4.6. Echinocandins and Pneumocandins …........................................................................................... 17

1.5. Looking for leads in the ethnopharmacology of Echinacea .....................................19

1.6. Echinacea's ethnobotany, history of use and clinical trials .............................................20

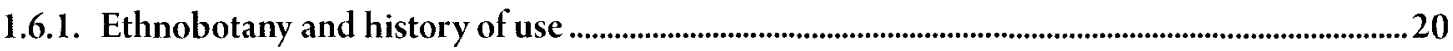

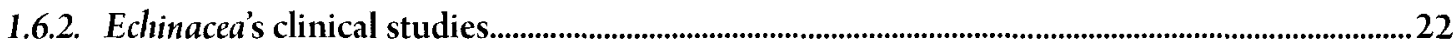

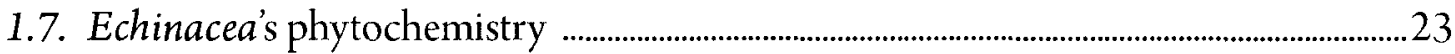

1.8. Pharmacological findings — The purple flower power..........................................................24

1.8.1. Echinacea's immunomodulation and anti-inflamatory proprieties ...............................................24

1.8.2. Echinacea's antioxidant properties......................................................................................................25

1.8.3. Echinacea's antifungal properties .................................................................................................25

1.9. Echinacea's pharmacodynamics and mode of action studies ...........................................27

1.9.1. Polysaccharides - Pharmacological findings …….....................................................................27

1.9.2. Caffeic acid derivatives (CADs) - Pharmacological findings ......................................................28

1.9.3. Alkamides — Pharmacological findings...............................................................................................28

1.9.4. Alkamide permeability to membranes and bioavailability...............................................................29

1.9.5. Alkamides immunomodulation and anti-inflammatory activities...................................................33

1.9.6. Alkamides — Mode of action studies........................................................................................................... 33

1.9.7. Alkamides and anandamine - the "bliss" molecule ..............................................................................35

2. The Aim of This Present Work .................................................................... 37 
3. Materials and Methods ............................................................................................ 38

3.1. Yeast strains and growth conditions ....................................................................................................38

3.1.1. S. cerevisiae wild type S288C and cell wall mutant YMR307W ...................................................38

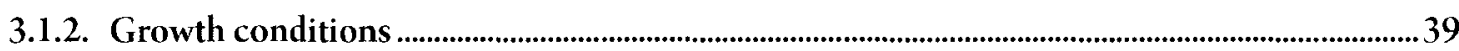

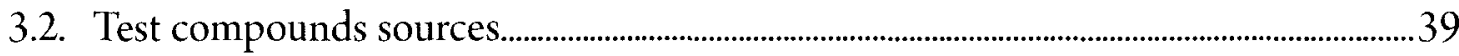

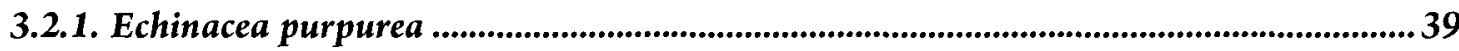

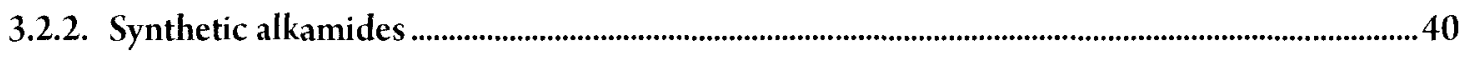

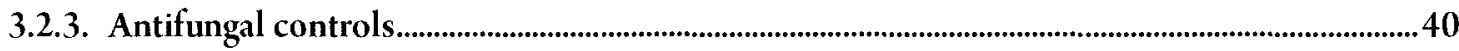

3.3. Antifungal susceptibility assays .................................................................................................44

3.3.1. Minimum inhibitory concentration (MIC) - Microdilution broth assay..................................44

3.3.2. MIC 40\% inhibition —Drop plate method ...................................................................................... 45

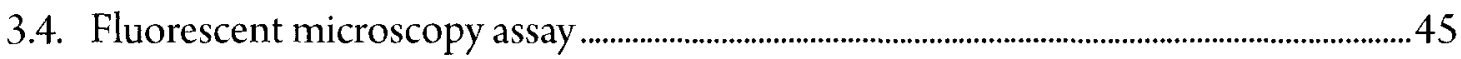

3.4.1. Treatment with test compounds .................................................................................................45

3.4.2. Ultrasound treatment - Mild sonication.........................................................................................46

3.4.3. Fluorescence microscopy ..............................................................................................................46

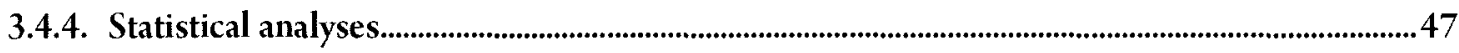

3.5. Alkamides QSAR modeling .......................................................................................................50

3.5.1. Calculation of the alkamide descriptors $(\log P)$ and biologic activity $(\log 1 / C) \ldots \ldots \ldots \ldots \ldots \ldots \ldots \ldots . . . .52$

3.5.2. Regression Analysis and model's goodness-of-fit evaluation .......................................................52

4. Results and Discussion ............................................................................................. 54

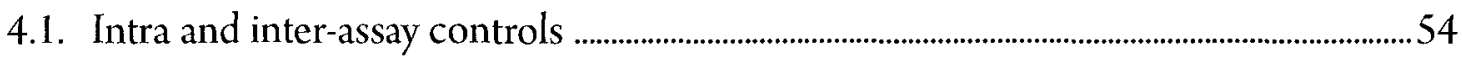

4.1.1. Minimum inhibitory concentration (MIC) determination .....................................................54 
4.2. Measuring yeast cell wall disruption by fluorescence microscopy ...................................59

4.2.1. Yeast cell wall disruption by ultrasound-induced cavitation .....................................................59

4.3. Cell wall damage and loss of viability observations ..............................................................61

4.3.1. Untreated Control ..................................................................................................................................61

4.3.2. Negative Controls ..................................................................................................................64

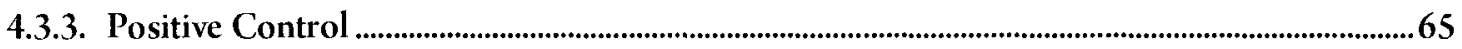

4.3.4. Test compounds —E. purpurea crude extract .........................................................................................68

4.3.5. Test compounds - Synthetic alkamides from Echinacea .............................................................. 70

4.4. Alkamides quantitative structure-activity relationships (QSAR) ....................................77

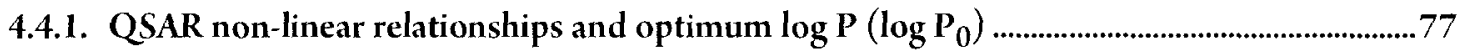

4.4.2. QSAR modeling of the growth inhibitory activity of alkamides .................................................79

4.4.3. Alkamides QSAR model: Regression analysis and model's goodness-of-fit...............................80

4.4.4. Alkamides drug-likeness —Lipinski’s rule of " 5 " ...............................................................................

4.4.5. Alkamides optimal $\log P\left(\log P_{0}\right)$ and "cut-off point"..........................................................................85

4.4.6. Alkamides $\log P$ and reported $\log P$ of antifungals and other compounds ..............................85

4.4.7. Correlation between antimicrobial activity and structural substituentes ....................................87

5. Summary and Conclusions .............................................................................. 91

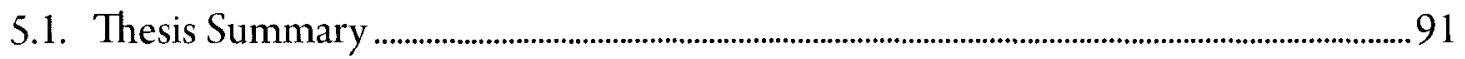

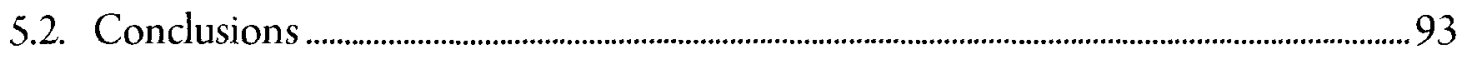

5.2.1. Antifungal activity of test compounds ...................................................................................................93 
5.2.2. Yeast cell wall/membrane complex disrupting activity of test compounds . .95

5.2.3. Alkamides QSAR modeling 102

5.2.4. Correlation between antimicrobial activity and structural substituents 106

5.3. Final conclusions 108

5.4. Future directions

6. Literature Cited

Appendix A

General observations of the effect of mild sonication on yeast cell suspensions 127 


\section{List of Tables}

Table 1. Synthetic alkamides used in this study

Table 2. Minimum inhibitory concentrations (MIC) results for the several test compounds used in this study

Table 3. Alkamide concentrations found in Echinacea purpurea roots as reported by several studies 58

Table 4. S. cerevisiae wild type S288C wall damage and cell death measurements ... 75

Table 5. S. cerevisiae cell wall mutant YMR307W cell wall damage and cell death measurements

Table 6. Calculated molecular lipophilicity descriptors ( $\log \mathrm{P})$ and average $\log \mathrm{P} \pm$ standard deviation for the synthetic alkamides used in the present study

Table 7. Alkamides molecular properties and Lipinski's Rule of 5 for $\log P \leq 5$, $\mathrm{MW} \leq 500, \mathrm{nON} \leq 10$ and $\mathrm{nOHNH} \leq 5$

Table 8. Predicted and experimentally observed $\log 1 / \mathrm{C}$ values and residuals for the alkamides QSAR models described by equations 3 and 4 


\section{Table of Figures}

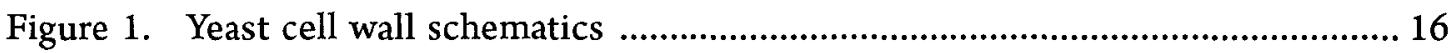

Figure 2. Image of flowers of Echinacea purpurea (L) Moench ............................... 19

Figure 3. Chemical names and molecular structures of the main alkamides from Echinacea (Woelkart and Bauer, 2007)

Figure 4. Structures of some of the alkamides tested in the Caco-2 CMM study by Matthias et al. (2004), illustrating the correlation between molecular structure and ability to cross membranes

Figure 5. Molecular structure of the endocannabinoid anandamide and alkamide $3 a$

Figure 6. HPLC profile of the E. purpurea extract used in the study showing UV absorbance vs. retention time

Figure 7. Structures of compounds used as antifungal controls in this study

Figure 8. Schematic diagram illustrating the several steps of the protocol for the fluorescent microscopy assay used to monitor cell wall damage in this study

Figure 9. Fluorescent microscopy images of S. cerevisiae S288C cells after treatment with Echinacea extract followed by sonication

Figure 10. Concentration of compounds required during 4 hour exposure to achieve $\sim 40 \%$ growth rate inhibition of yeast

Figure 11. Micrographs of S288C yeast cells treated with Echinacea extract for 4 hours prior to sonication and then simultaneously stained with CFW and Evans Blue

Figure 12. Fluorescence microscopy images of $S$. cerevisiae $S 288 \mathrm{C}$ untreated control cells with no sonication $(-T /-S)$ 
Figure 13. Fluorescence microscopy images of S. cerevisiae S288C untreated control cells subjected to sonication $(-T /+S)$

Figure 14. Histogram illustrating the effect of treatment of the yeast cells with the test compounds with no sonication $(-)$ Son

Figure 15. Histogram summarizing the effect on yeast cells of exposure to test compound followed by mild sonication

Figure 16. Graphic representation of equation (2b), Hansch's QSAR non-linear relationships between $\log 1 / \mathrm{C}$ and $\log \mathrm{P}$ where the curve is a parabola and optimum $\log \mathrm{P}_{0}$ is the apex of the parabola

Figure 17. Plots of predicted versus experimentally observed (Table 7) inhibitory activity of synthetic alkamides from Echinacea against $S$. cereviseae wild type S288C (left panel) and cell wall mutant YMR307W (right panel) strains

Figure 18. Alkamides $\log \mathrm{P}$ in relation to the reported $\log \mathrm{P}$ of several other compounds

Figure 19. Correlation between the alkamides molecular structure and antifungal activity against $S$. cerevisiae 90

Figure 20. Fluorescence microscopy images of yeast S. cerevisiae YMR307W stained with CFW illustrating the effect of mild sonication in dispersing the typically budded cell aggregates characteristic of this strain

Figure 21. Effect of mild sonication on yeast cell aggregation

Figure 22. Drop out plate image illustrating how the effect of mild sonication on the cell aggregations typical of YMR307W can create results where more CFUs are present in the sonicated sample when compared with the non-sonicated control. 


\section{List of Abbreviations}

5-LOX - 5-lipoxygenase

AIDS - Acquired immunodeficiency syndrome

appHC - Apparently healthy cell

BMM - Broth microdilution method

CADs - Caffeic acid derivatives

CAS - Caspofungin

CB1/CB2 - Cannabinoid receptors type 1 and 2

CFW - Calcofluor white stain

CFU - Colony forming units

clonNAT/NAT - Nourseothricin

CMM - Caco-2 cell monolayer model, an intestinal barrier model

COX-1/COX-2 - Cyclooxygenase 1 and 2

CWD - Cell wall damage

CWI - Cell wall integrity pathway

CWP - Cell wall protein

DAPI - Fluorochrome 4',6-diamidino-2-phenylindole

Delta-9-THC - Delta 9-tetrahydrocannabinol 
DNA - Deoxyribonucleic acid

DHA - Docosahexaenoic acid

DPM - Drop plate method

EB - Evans blue stain

EB+ - Evans blue stained yeast cell

ECH - Echinacea extract

EtOH - Ethyl alcohol

FDA - Food and Drug Administration

GDA - Gene deletion array

GPI - Glycosylphosphatidylinositol

GPI-CWP - GPI-anchored cell wall protein

HC - Healthy cell

HIV - Human immunodeficiency virus

HPLC - High performance liquid chromatography

HYG - Hygromycin B

$\log 1 / \mathrm{C}$ - Inverse logarithm of the molar concentration of a compound that causes $\sim 40 \%$ growth inhibition

Log P - logarithm of octanol-water partition coefficient 
IOFIs - Invasive opportunistic fungal infections

MIC - Minimum inhibitory concentration

MW - Molecular weight

NSAIDs - Nonsteroidal anti-inflammatory drugs

Pir - Protein member of the PIR gene family

(Proteins with Internal Repeats)

Pir-CWP - A cell wall protein from the PIR family linked through an alkali-sensitive linkage to $\beta 1,3$-glucan.

QSAR - Quantitative structure-activity relationship

$\mathbf{r}^{2}-$ Coefficient of determination

s - Standard deviation

(-T/-S) - Untreated non Sonicated sample

$(-T /+S)-$ Untreated and Sonicated sample

(+T/-S) - Treated non Sonicated sample

$(+\mathrm{T} /+\mathrm{S})-$ Treated and Sonicated sample

URTI - Upper respiratory tract infection

WHO - World Health Organization 


\section{General Introduction}

\section{Antimicrobial resistance - The major global health challenge of the 21st century}

\subsection{A need for new antimicrobials}

The emergence of microbial pathogens that are resistant to existing antibiotics combined with an increasing incidence of invasive opportunistic microbial infections has become a major health concern affecting developed and developing countries alike. This microbiological-related health issue is complex, incorporating biological, environmental, geopolitical, socio-economic and demographic factors that are unique to recent times. The reality is that the constant evolution and natural selection for drug resistance is ubiquitous in nature and cannot be stopped. However, the misuse of antimicrobials both inside and outside of human medicine in many instances has facilitated the emergence of drug resistant microbial strains (WHO, 2002a).

Poor socio-economic conditions are partly accountable for the misuse of antimicrobials in human medicine. The lack of access to proper diagnostic and follow up treatment in combination with the unregulated sale of antimicrobials, a common practice in many developing countries, results in self-medication, unnecessary use of antimicrobials as prophylactic and usage of suboptimal dosage and/or substandard drugs (counterfeits, expired or improperly stored). The non-compliance with the full course of therapy is also a factor contributing to the emergence of resistant microbial strains. Non-compliance happens quite often, either because the patient cannot 
afford the medication or cannot tolerate the toxicity, particularly when an extended length of treatment is required.

While the antimicrobial misuse in developing nations is for the most part due to underuse, overuse is rampant in wealthy nations. It is estimated that $50 \%$ of the global antimicrobial production is used in animal farming, including aquaculture (WHO, 2002b). Here, antimicrobial agents are extensively used not only for the treatment of infectious diseases but also as prophylactics and growth promoting agents. A consequence is that large numbers of livestock are exposed to subinhibitory concentrations of antimicrobials. Even the petroleum industry uses biocides in oil production facilities to inhibit the overgrowth of microorganisms and consequent biofilm formation, which can block pipes and produce toxic and corrosive by-products. This creates a real threat to the environment through potential leakage of these antimicrobials into the environment (Korenblum et al., 2005).

The intensification of global trade and new dynamics in population movements are playing an important role in the spreading of the above mentioned problems as the results of poor antimicrobial use practices in any given country are not self-contained anymore and have become a threat to everyone everywhere (WHO, 2002b).

\section{The rise of invasive opportunistic fungal infections}

Along with the rise in antimicrobial resistance observed in the last three decades, there has been the increase in invasive opportunistic fungal infections (IOFIs). Fungal infections have jumped from the tenth to the seventh most prevalent cause of death by infectious disease in the United States from 1980 to 1997 (McNeil et al., 2001). Although relatively rare in healthy individuals, currently, 
IOFIs are a major cause of morbidity and mortality in immunocompromised patients where mortality rates range from 50 to 90 percent and approach 100 percent in cases of invasive aspergillosis in solid organ transplant recipients (Aronchick, 2000; McNeil et al., 2001; Minari et al., 2002; Franquet et al., 2004). The surge observed in the frequency of these life-threatening fungal infections appears to be directly associated with an expanding population of immunocompromised individuals. A variety of sub-groups make up this population, including individuals with underlying immunocompromising conditions such as HIV/AIDS, congenital immunodeficiencies, patients under aggressive immunosuppressive treatments used in solid-organ, blood and marrow transplantation, and anti-neoplastic therapies. Another sizable sub-group comprises patients hospitalized with severe illness, including the elderly, pre-term neonates and malnourished infants, whose supportive care includes the use of invasive devices for monitoring, parenteral nutrition and assisted ventilation, just to name a few. Ironically, the successes of recent advances in healthcare technology and antifungal chemoprophylactic practices such as the prescription of prolonged course of broad spectrum antibiotics to transplant patients that have resulted in the improved survival of patients with life-threatening conditions, have likewise increased the number of individuals at high risk of contracting nosocomial infections (Singh, 2001; Franquet et al., 2004; Francois et al., 2005).

\section{The emergence of new fungal pathogens}

Immunocompromised patients are highly susceptible to invasive mycoses caused by fungi commonly considered to be of low virulence or non-pathogenic to mammals. The majority of IOFIs are caused by Candida albicans, in the case of bloodstream infections; Aspergillus fumigatus, in transplant recipients; and 
Cryptococcus neoformans, observed in 5-10\% of HIV infected patients (Walsh et al., 2004; Richardson, 2005). Although advances in retroviral therapies to treat HIV have reduced its incidence, cryptococcosis is still a problem in developing nations where, due to the cost, triple combination antiretro-viral therapies are not widely available to HIV patients. Nonetheless, epidemiological data collected during the past decade indicate an upward trend in infections caused by less common fungal pathogens such as Aspergillus species other than A. fumigatus, Candida spp. aside from C. albicans, members of the Mucoraceae, and Fusarium species. Fusarium infections are not very common but are particularly severe in cancer patients, where there is a very poor prognosis; a mortality rate of $52-70 \%$ and close to $100 \%$ in non-recovered neutropenic patients. A variety of other emerging fungi has been recognized to cause IOFIs with high case fatalities rates: Scedosporium spp., Acremonium spp., Trichoderma spp., Trichosporon spp., among others (Groll and Walsh, 2001; Pfaller and Diekema, 2004; Walsh et al., 2004). These life threatening fungal infections have non-specific symptoms making diagnosis difficult and many are identified only at autopsy. The related infections are also usually difficult to treat, as many emerging fungal pathogens are already resistant to the existing anti-fungals (Richardson, 2005). OIFIs typically occur in conjunction with other conditions, therefore the cost of treating these infections is difficult to calculate but it is estimated at $\$ 2.6$ billion/year in the United States alone (Wilson et al., 2002).

In view of the recent epidemiological trends of an ever-growing population of immunocompromised hosts, the rise in the incidence of uncommon opportunistic mycoses and antifungal resistance, it is clear that the prevention and treatment of OIFIs will remain a major challenge that needs to be addressed urgently through 
the commitment of more resources to the discovery and development of novel, more effective, safer and less toxic antifungal therapeutics. Besides the human health issue, the search for new antimicrobials is driven also by the need to ease the severe economic impact caused by fungal plant pathogens and fungal contamination and spoilage of crops, food, animal feed and raw materials that plagues agriculture, forestry, fishery and food industry in general.

The topic of this thesis is investigation of antifungals from Echinacea. In the following sections I describe some necessary background on antimicrobials and then focus specifically on the yeast cell wall and antifungals from Echinacea that are thus relevant to the topic of this thesis. 


\subsection{Current antimicrobial research}

\section{When misguided perception meets reality}

"Even if the pharmaceutical industry were to step up efforts to develop new replacement drugs immediately, current trends suggest that some diseases will have no effective therapies within the next ten years" - WHO, Fact Sheet \#194, 2002.

It is reasonable to say that the mid-1900s was the golden era of antimicrobial discovery. Since then, a misguided ongoing perception that infectious diseases have been conquered has brought the development of novel antimicrobials to a standstill (WHO, 2002a). With the exception of the development of very expensive antiretroviral HIV drugs and a few antifungals, the pharmaceutical industry has since pursued more profitable endeavors in the treatment of chronic conditions such as cancer, diabetes, heart diseases, depression, mood disorders and erectile dysfunction. The result of decades of under investment is that researchers now have to play catch-up to microbial evolution. Needed for this is a greater understanding of the mechanisms of action of antimicrobials and novel approaches to identify unique antimicrobial drug targets.

\subsubsection{Bio-prospecting for new antifungals}

\section{Searching the shelves of Nature's cupboard for answers}

There was a time in our short history on this planet when nature was the only source of remedy for all our maladies. This is still the reality for the majority of the population in developing nations where access to modern medicine is a luxury. It is estimated that $80 \%$ of the population in developing countries in Africa and Asia rely 
on traditional medicine for health care (WHO, 2008). Moving along the timeline of the modern era, as new knowledge of chemistry and biology and advances in synthetic organic chemistry are acquired, the development of the modern pharmaceuticals, better known as prescription drugs, became possible. Notwithstanding our advances in science, the discovery and development of novel pharmaceuticals remains a complex, time consuming and very expensive business. As a case in point, it takes about $10-15$ years and US $\$ 800$ million to US $\$ 1$ billion to bring one pharmaceutical out of 10,000 potential compounds from basic pharmacological research to the market (PhRMA, 2007). Therefore, more effective strategies are required to streamline and reduce time and cost of drug development.

\subsubsection{Reverse pharmacology}

\section{Studying the ethnopharmacology of natural products}

A very promising and proven strategy is the reverse pharmacology approach; drug development through study of the ethnopharmacology of natural products. In this approach, traditional knowledge is used as a "search engine" to tap into generations of accumulated knowledge of indigenous peoples and healers. This approach may shorten the long list of potential drug candidates and reduce the possibility of undesirable side effects that are discovered only in final stages of clinical trials. The screening of randomly collected samples of plants and microorganisms in the hope of finding organic compounds with biological activity has also shown promising results. 
The above two approaches are not original ideas. What is original is that the powerful, innovative and highly automated biotechnologies and interdisciplinary expertise that has been developed over the past decades, such as bioinformatics, cheminformatics and pharmacogenomics, can now be used to expedite the discovery of new drugs by either process. Naturally-derived compounds of interest can be more easily isolated by computerized chromatographic methods and their molecular structure can be determined by spectroscopic methods. Biological activities of molecules can be predicted by quantitative structure-activity relationship (QSAR) analysis. Molecular targets can be inferred by analysis of the activities of similar molecules with known mode of action. Synthetic analogs can be designed by sophisticated molecular modeling software that relies heavily on computer power. Entire genetic libraries of model microorganisms, such as $S$. cerevisiae and $E$. coli, with complete genomic DNA sequences at our disposal, can be used in highthroughput functional genetics technologies to elucidate the molecular mechanism of action of compounds (Galván et al., 2008). Still, when it comes to the screening of natural products, researchers are faced with a multitude of compounds with potentially useful pharmacological activity. Hence the need for efficient screening assays. From initial screening of a natural product, pure extract preparation, to the isolation of potentially useful chemical structures and final molecular modification or synthetic analogs production, it remains a long way to the clinical trials phase and final regulatory approval. 


\subsubsection{Finding biological active compounds in nature}

\section{Hard work and serendipity in antifungal discovery}

Remarkably, either by design or by serendipity, pharmaceuticals derived from natural products make up approximately $50 \%$ of all drugs in use today. Most of these natural products come from plants and microorganisms, with $25 \%$ derived from plants sources (Balandrin et al., 1993). From the numerous alkaloids of the opium poppy (Papaver somniferum) that include morphine and codeine, to the yew tree (Taxus brevifolia) from where the best selling (peak sales of US\$1.6 billion in 2000) antitumor agent Taxol was derived (Stephenson, 2004), medicinal plants have proven to be a reliable source of biologically active molecules (Cowan, 1999; Ficker et al., 2003). For a review of the new drugs derived from natural products in the last 25 years see Newman and Cragg (2007). In the realm of the microorganisms, the classic example of drug discovery by serendipity was in 1928, when Alexander Fleming characterized the compound considered as the first antibiotic: penicillin from Penicillium chrysogenum (Diggins, 2000).

Several antifungal compounds have been discovered from microbial sources as well. One example was the discovery of the antifungal griseofulvin from Penicillium griseofulvum in the 1960s. This is the first reported case where a secondary metabolite of a fungus is used to inhibit the growth of another fungus. Griseofulvin inhibits mitosis by blocking the assembly of microtubules, but its use is limited to the treatment of dermato-mycosis (Odds, 2003). Perhaps the most notable example of microbial bio-prospecting for antifungals lead to the discovery in 1955 of the polyene amphotericin B from a gram-positive filamentous soil bacterium, 
Streptomyces nodosus. This species was isolated from a soil sample taken from the Orinoco River region in Venezuela (Trejo and Bennett, 1963). Polyenes attach preferentially to ergosterol, the principle steroid compound of the fungal cell membrane (as opposed to the sterol in human cell membranes), and create channels that result in membrane leakage and a change in osmolarity from which the cell cannot recover (Ghannoum and Rice, 1999). For nearly 30 years, amphotericin B was the only choice to control invasive mycoses until the discovery of a new synthetic class of antifungals: the azoles. Azoles, such as fluconazole and voriconazole, inhibit a late step on the synthesis of ergosterol catalyzed by a cytochrome P450 and result in a defective membrane through the accumulation of toxic sterol intermediates in the cell membrane (Odds, 2003). 


\subsection{Selective cytotoxicity and the yeast cell wall}

Nonetheless all the latest progress, most currently available antifungals lack selective cytotoxicity. The biochemical similarities between fungal cell and animal cell make it difficult to develop antifungals that are selectively toxic to fungi. However, the fungal cell wall and its assembly line represent a clearly defined difference to the animal cell that can be exploited in the search for antifungals with selective cytotoxicity-A very much desired trait in antifungals.

\subsection{A unique antifungal target - The fungal cell wall}

Representing $\sim 30 \%$ of the dry weight of the fungal cell (Nguyen et al., 1998) the cell wall is a layered structure that encases the fungal cell, but rather than being just a rigid incasing structure responsible for maintaining the cell shape and protecting it from environmental aggressions, the fungal cell wall is a complex and dynamic organelle, constantly being remodeled and regenerated to accommodate the changes that take place according to the cycle of the cell life (budding, mating, sporulation and pseudohyphal formation) or in response to environmental challenges (Cabib et al., 1982; Smits, 2001). Consequently, any major disruption in the biosynthesis, assembly or function of the cell wall is lethal to the fungal cell viability, therefore the cell wall is one of the most desirable targets in the development of new antifungal drugs. 


\subsubsection{The yeast cell wall bilayered structure}

The yeast cell wall bilayered structure (Figure 1) consists of $10-15 \%$ protein and $85-90 \%$ polysaccharides comprised of three sugars: glucose, mannose, and $\mathrm{N}$-acetylglucosamine. Most of the proteins found in the cell wall are located in the outer layer and are covalently linked to mannan (a polymer of the sugar mannose), hence the classification as mannoproteins. Located in the inner layer are the glucose

polysaccharides $\beta$-1,3-glucan and $\beta$-1,6-glucan, the major structural components accounting for $\sim 60 \%$ of cell wall dry mass, and chitin, the $\beta$-1,4-linked polymer of $\mathrm{N}$-acetyl-glucosamine which accounts for $1.5-6 \%$ of cell wall dry mass. (Nguyen et al., 1998; Klis et al., 2006).

\subsubsection{The external layer of the cell wall - Mannoproteins}

The external cell wall layer consists mainly of mannoproteins which accounts for $30-50 \%$ of the cell wall dry mass (the protein content is only $4-5 \%$; the remaining mass is from highly branched carbohydrate side-chains). The majority of cell wall proteins (CWP) found in the outer cell wall layer of S. cerevisiae are GPI-anchored proteins (GPI-CWPs) - In eukaryotic cells many proteins are anchored to membranes by covalent linkage to glycosyl-phosphatidylinositol (GPI) thus located in the extracellular side of the plasma membrane or cell wall in the case of the yeast cell; these are known as GPI-anchored proteins. GPI-CWPs are in most cases indirectly linked to $\beta$-1,3-glucan through a connecting $\beta$-1,6-glucan molecule. Another group of CWPs are the Pir-CWPs; these are thought to link directly to $\beta-1,3$-glucan (Zlotnik et al., 1984; Cabib et al., 2001; Klis et al., 2002). The outer layer of mannoproteins protects the fungal cell against enzymatic damage and limits the permeability of the cell wall 
acting as a filter for large foreign macromolecules. CWPs are involved in several important cell functions such as mating, flocculation, biofilm formation and strain invasiveness. For a review of cell wall proteins see Klis et al. (2002) and De Groot et al. (2005).

\subsubsection{The inner layer of the cell wall $-\beta$-glucans}

The inner layer of the yeast cell wall plays a crucial role in the structural integrity of the fungal cell. This layer is an intricate three-dimensional network of glucose polymers, mostly long chains of $\beta$-1,3-glucose molecules (85\%) and short chains of $\beta$-1,6-glucose molecules (15\%) and a smaller amount of chitin (Figure 1). The $\beta-1,3$-glucan is the major structural component of the cell wall to which the other components are crosslinked forming a elastic scaffold-like structure that encapsulates the fungal cell providing structural support. The combination mechanical strength and elasticity protects the cell from physical damage while the scaffold like crosslinkage provide support for the external layer of mannoprotein as well as an array of cell wall proteins (non-covalent bound, covalently bond and GPI-anchored) whose functions are still to be established.

The cell wall $\beta$-1,3-glucan is synthesized by $\beta-1,3$-glucan synthase at the plasma membrane. This enzyme is thought to consist of catalytic subunits of Fkslp and its alternative subunits Gsc2p/Fks2p and Fks3p; and a regulatory subunit, a small GTPase Rholp that plays an essential role in the control of the cell wall synthesis, as it binds and activates the Fkslp catalytic unit. Fkslp shares $88 \%$ similarity with its alternative protein Fks2p, and 55\% with Fks3p. While a deletion of FKS1 causes a decrease in $\beta$-glucan and an increase in chitin and mannoprotein 
levels in the cell wall, a deletion of FKS2 causes no obvious cell wall defect. However, cells lacking both FKS1 and FKS2 are not viable, an indication that Fks1p and Fks2p have overlapping functions in the synthesis of the cell wall $\beta$-glucan. As far as the role of FKS3, a fks $3 \Delta$ mutant shows no apparent cell wall defects or genetic interactions with FKS1 or FKS2 and thus it has not been implicated in cell wall glucan synthesis (Dijkgraaf et al., 2002; Klis et al., 2002; Klis et al., 2006).

In addition, $\beta$-1,3-glucan is synthesized as a linear polymer, but after leaving the plasma membrane, further extension by other enzymes and remodeling results in branching. A well studied enzyme thought to be involved in this remodeling is Gaslp. This $1,3-\beta$-Glucanosyltransferase is attached to the extracellular face of the plasma membrane via a GPI-anchor and has been implicated in remodeling and cross-linking linear $\beta$-1,3-glucan chains produced by the $\beta$-glucan synthase (Mouyna et al., 2000). A GAS1 deletion results in a cell with a weakened wall and abnormal morphology. These GASI mutants are larger with a more spherical shape and exhibit a higher percentage of budded and multiple budded cells that form aggregates that are difficult to disperse. This phenotype may indicate that GAS1 is involved in the process of separation of the bud from mother cell (Popolo et al., 1993). GAS1 mutants are known to release $\beta-1,3$-glucan and $\beta-1,6$-glucosylated wall proteins into the medium (Ram et al., 1998) and are observed to have an increase in chitin deposition and an alternative cross-linking of $\beta$-1,6-glucosylated wall proteins to chitin. This probably partially compensates for the defective $\beta$-1,3-glucan polymer (Popolo et al., 1997). The remaining cell wall $\beta$-glucan is the highly branched $\beta$-1,6-glucan. With an average of 130 glucose monomers, the main function of this polymer in the cell wall is to act 
like a glue connecting GPI-anchored cell wall proteins to the $\beta$-1,3-glucan network. In case of cell wall disruption $\beta$-1,3-glucan can also function as an acceptor site for chitin, thus interconnecting all major cell wall components (Klis et al., 2006).

\subsubsection{The inner layer of the cell wall- Chitin}

Chitin, a $\beta-1,4-$ linked linear polymer of $\mathrm{N}$-acetylglucosamine, is uniformly dispersed in the lateral walls of the yeast cell and is most abundant in the chitin ring seen in and around the bud scars. The total chitin level in the yeast cell wall, including the bud scar chitin is $1-2 \%$. The lateral wall chitin level is only $0.1-0.2 \%$. However, the amount of chitin can increase up to $20 \%$ of the wall dry mass if a compensatory mechanism is triggered in an effort to salvage the cell from severe cell wall impairment such as cell wall mutations or exposure to drugs. Despite its small quantity, chitin is thought to have a central role in septation and it is essential to the survival of cell wall mutants such gas1 (Klis et al., 2002; Lesage et al., 2005).

\subsubsection{The cell wall regulatory apparatus}

To maintain the complex structure of the fungal cell wall a considerable amount of energy and a tightly controlled regulatory apparatus is required, which is often referred to as the cell wall integrity pathway. De Groot et al. (2001), estimated that about $20 \%$ of Saccharomyces cerevisiae genes have a cell wall biogenesis-related function. This, together with the fact that the make-up of the fungal cell wall is unique to the fungi, make the cell wall and the cell wall integrity pathway the most desirable targets in the development of new, highly specific antifungal drugs. 


\section{Yeast cell wall diagram}
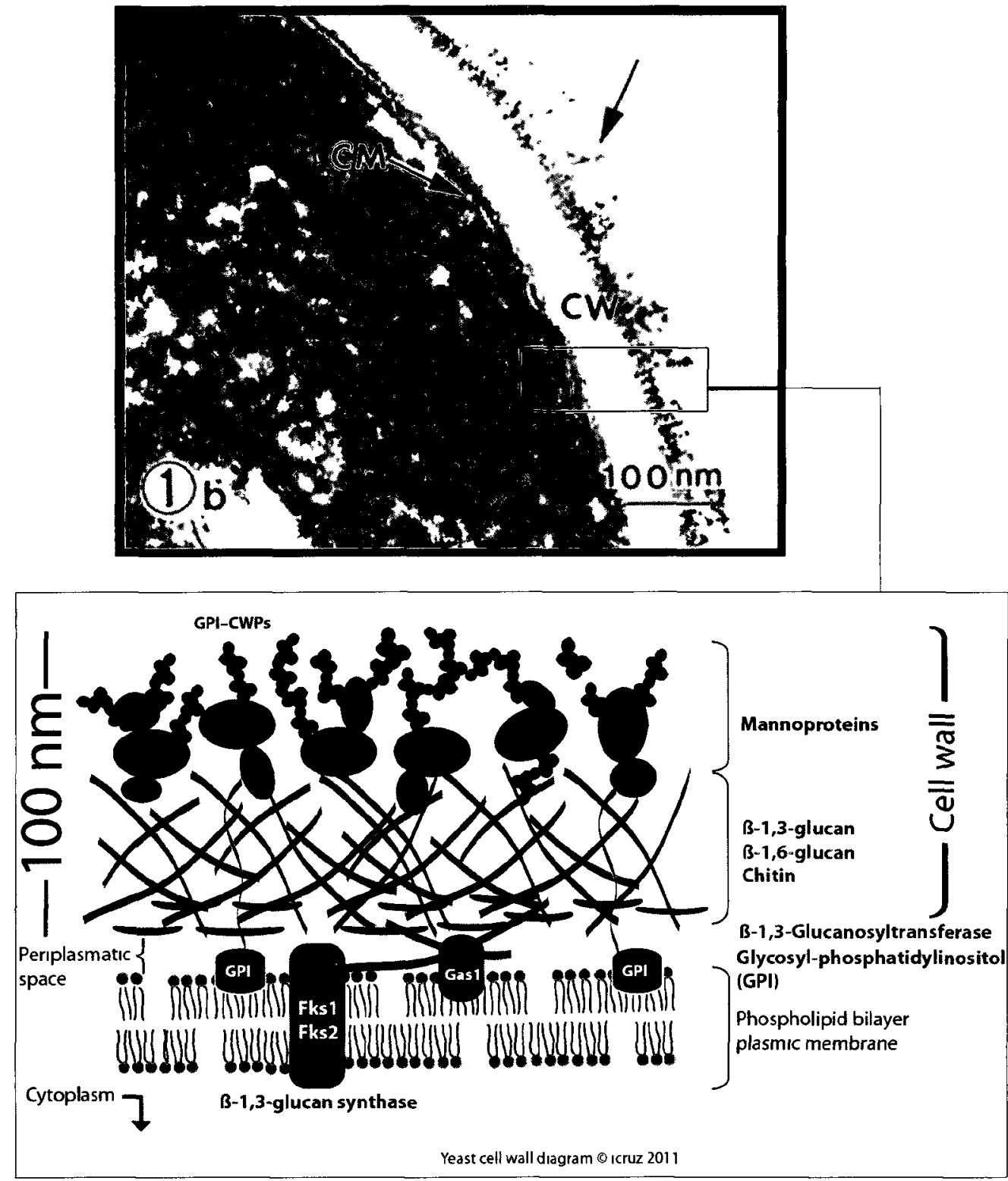

Figure 1. Electron micrograph and schematic diagram of the yeast cell wall. Top panel is a transmission electron microscope image showing $S$. cerevisiae cell membrane and wall (Baba and Osumi, 1987). Bottom panel is a diagram of the section selected by a rectangle in the top panel. The outer layer of cell wall proteins (Mannoproteins, GPI anchored and others) and the inner layer comprisêd of a network of $\beta-1,6$ glucan, $\beta-1,3$-glucan and chitin are indicated. A schematic of the main proteins involved in the formation of the cell wall, $\beta-1,3$-glucan synthase(Fks1/Fks2) and $1,3-\beta$-glucanosyltransferase (Gas1) are also indicated in the bottom panel. The image in the top panel was reproduced with permission of the copyright holder John Wiley \& Sons, Inc., from Baba and Osumi, 1987. 


\subsubsection{Echinocandins and Pneumocandins}

\section{The fungal cell wall has been broken}

Since the discovery that penicillin acts by disrupting the bacterial cell wall, researchers have been trying to find compounds that disrupt the fungal cell wall. The first step in this direction was taken when echinocandin $B$, a $\beta$-1,3-glucan synthase inhibitor, was isolated from a species of Aspergillus in 1974 (Denning, 1997). The breakthrough came in 1989 when MERCK researchers isolated a closely related group of compounds from the fermentation of Glarea lozoyensis (Schwartz et al., 1989), a dematiaceous hyphomycete formerly known as Zalerion arbicola, which itself was discovered in water samples from ponds in the valley of the Lozoya River, Spain in 1985 (Bills et al., 1999). The compounds were named pneumocandins by MERCK to imply that Pneumocystis carinii and Candida spp where the target microorganisms, but they are in fact echinocandins (Denning, 1997).

Echinocandins and pneumocandins represent a highly specific class of antifungal drugs that act by inhibiting the enzyme $\beta$-1,3-glucan synthase; this enzyme complex is responsible for the production of $\beta-1,3$-glucan, a major component in the cell wall of many fungi as discussed above. As a result of $\beta-1,3$-glucan synthase inhibition, fungal cell wall integrity is compromised, leading to abnormal growth, reduced cell wall strength, osmotic instability, and ultimately cell lysis and cell death (Onishi et al., 2000; Denning, 2003). Since its discovery, structural alterations to the lead molecule pneumocandin B0 have produced semi-synthetic derivatives with improved potency and an enhanced spectrum of activity. Caspofungin acetate (Cancidas, Merck/FDA approved 2001) was the first echinocandin approved for treatment of infections by 
Candida and Aspergillus species that were resistant to traditional antifungals; it has also shown activity against Pneumocystis pneumonia (Letscher-Bru and Herbrecht, 2003). In addition to caspofungin, two new echinocandins have been approved for human use: Micafungin (Fujisawa/FDA approved 2005) and Anidulafugin (PfizerFDA approved 2006). These echinocandins represent important advances in the treatment of life-threatening fungal infections, as their mode of action is very different from that of any other available antifungal compound. On the other hand, they are not effective against Cryptococcus, nor against Fusarium so the search continues... 


\subsection{Looking for leads in the ethnopharmacology of Echinacea}

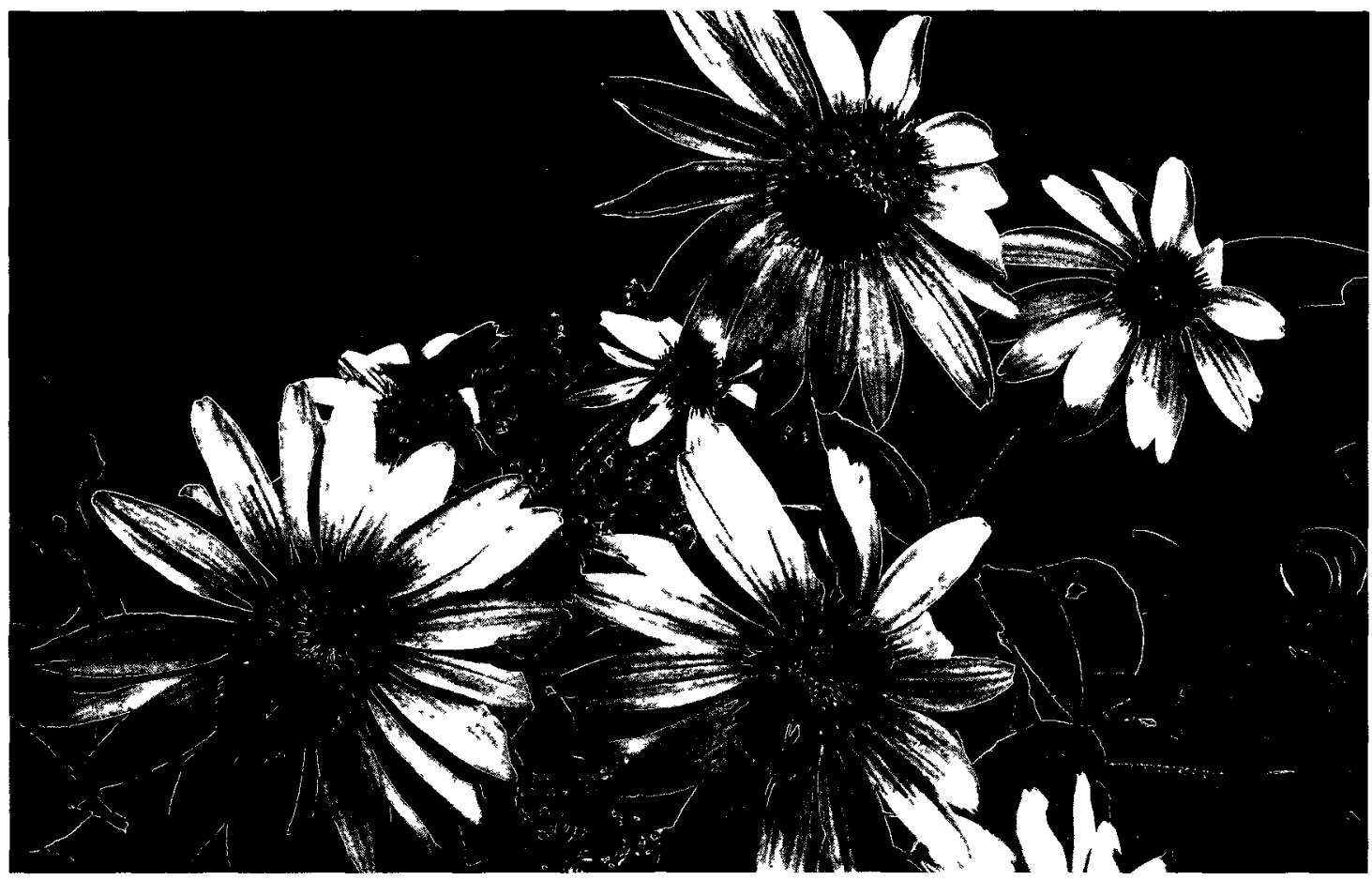

Figure 2. Echinacea purpurea (L) Moench

The genus Echinacea comprises four species of perennial coneflowers plants in the family of Asteraceae that are native to the plains of central United States and southern Canada. Echinacea was named after the Greek word for hedgehog-echinos, which refers to the resemblance of its prickly conical seed head to the spines of a hedgehog. Purple varieties of this genus are known as purple coneflower. Echinacea taxonomy, ecology, geographic distribution, ethnobotany and history of use have been thoroughly studied and masterfully reviewed by other authors (Felter, 1898; McGregor, 1968; Shemluck, 1982; Kindscher, 1989; Borchers et al., 2000; Binns, 2001; Miller and Yu, 2004; Kindscher, 2006) and, therefore, will not be discussed in depth here. The following account is a summary of these various studies. 


\subsection{Echinacea's ethnobotany, history of use and clinical trials}

\subsubsection{Ethnobotany and history of use}

For centuries the Great Plains tribes of Native Americans used Echinacea preparations by chewing the roots or topically applying a poultice of mashed roots to treat infections, toothaches, sore throats, coughs, wounds, burns, mumps, and venomous bites and stings. Also noteworthy is the fact that the use of medicinal herbs by Native Americans has a strong spiritual healing component, rather than straightforward acknowledgment of the chemical properties of the herbs used (Shemluck, 1982; Kindscher, 1989; Borchers et al., 2000). Many medicinal herbs traditionally used by the Native Americans including Echinacea were adopted by early European settlers in North America (Kindscher, 1989). Echinacea was introduced to Europe where it became popular in the 18th and 19th centuries. In North America, the Eclectic practitioners (these were somewhere between homoeopaths, allopaths, and physicians) prescribed it as a remedy to treat a wide variety of conditions ranging from upper respiratory tract infections, colds and influenza, urinary tract infections, fevers (scarlet, malaria, typhoid), syphilis, sore throat, blood poisoning, diphtheria and impotence (Felter, 1898).

In the first half of the 20th century the use of antimicrobial herbal medicines, including Echinacea, declined when sulfonamides and other antibiotics were introduced thereafter. Later in the same century, Echinacea gradually regained popularity largely in Germany where, since then, the bulk of scientific research on Echinacea has been done. Nowadays, Echinacea preparations are one of the most 
popular herbal remedies in North America, primarily for treating colds and the flu. The National Center for Health Statistics survey of 2007 found that the most commonly used non-vitamin, non-mineral natural product used by adults in the United States were: fish oil or omega 3 or DHA (37.4\%), glucosamine (19.9\%), and Echinacea (19.8\%). In the case of children, Echinacea (37.2\%), fish oil or omega 3 or DHA (30.5\%) and combination herb pill (17.9\%) are the most common natural health products used (Barnes et al., 2008). Furthermore, Echinacea herbal preparations ranked 5th in the 20 top-selling herbal dietary supplements in the food, drug and mass market channels (health and natural food stores; food, drug and mass market retailers; warehouse and convenience stores; mail order, radio and television direct sales; internet sales; health professionals and others categories) in the Unites States in 2009 , with $\$ 16$ million (USD) in sales and almost $7 \%$ increase from 2008 (Cavaliere et al., 2010). Unfortunately, such popularity has come at a price. Although sustainably cultivated throughout the United States, Canada and Europe, over-harvesting of wild Echinacea for the herbal industry is creating enormous pressure on the natural population of Echinacea, raising a concern that the species most commonly used in the medicinal herb industry. E. pallida var pallida, E. pallida var angustifolia and E. purpurea may be in danger of depletion beyond recovery and will soon follow the steps of Echinacea laevigata and Echinacea tennesseensis that are now listed as endangered by the United States Fish and Wildlife Service (Kindscher, 1989, 2006). 


\subsubsection{Echinacea's clinical studies}

Presently, the most common medicinal use of Echinacea is to prevent, shorten the duration, and treat the symptoms of upper respiratory tract infections (URTIs), such as colds and the flu. The main reason for this recent gain in popularity appears to be Echinacea's reported non-specific immunomodulatory properties. Several metaanalysis studies and reviews have been done in an effort to compile the results of hundreds of clinical studies on the effectiveness of Echinacea to reduce the incidence and duration of the common cold (Cochrane Database of Systematic Reviews, 2006; Schoop et al., 2006; Shah et al., 2007; Woelkart et al., 2008a; Toselli et al., 2009). The general consensus is that while there is evidence of Echinacea's efficacy in treating the common cold and of its preventive properties, there is just too much heterogeneity between clinical trials to make reliable conclusions possible. Problems with trials include: variability in the composition of the Echinacea preparations used in clinical trials (use of different species or species combinations, plant parts, extraction methods and combination with another herbal product), and variations in the study designs (virus type-spontaneous acquired or rhinovirus-induced, double blind placebo controlled or not, time of the initiation of treatment, age, number and immunological condition of subjects). Therefore, large-scale clinical trials with precisely standardized study designs are needed to provide definitive scientific evidence of Echinacea's clinical effectiveness in the prevention and treatment of common cold. 


\subsection{Echinacea's phytochemistry}

\section{The chemical make up of a best seller}

Comprehensive research has been done to determine the phytochemistry of the three most medically-used species of Echinacea-E. pallida var pallida, E. pallida var angustifolia and E. purpurea. Much of that research has been done by Bauer (Bauer et al., 1988a; Bauer et al., 1988b; Bauer et al., 1988c, 1989) and Binns (2002) and extensively reviewed in Hall and Schwarz (2002) and Barnes (2005). It is well established that the chemical composition of Echinacea spp is a complex mix of hydrophilic compounds, mostly caffeic acid derivatives (CADs-echinacoside, chicoric acid, caftaric acid, cynarin), glycoproteins and polysaccharides; lipophilic components, by and large alkamides and polyacetylenes; volatile essential oils, and a series of other minor constituents such as alkaloids, flavonoids, anthocyanins, and free phenolic acids. It is also well documented that the phytochemical profile of Echinacea extracts varies between species and within species depending on harvesting technique, geographic location, parts of the plant used and extraction methodology (Binns et al., 2002; Qu et al., 2005). As a case in point, all three species contain both the hydrophilic and lipophilic components, however, alkamides are unique to the roots of E. pallida var angustifolia and E. purpurea and for the most part nonexistent in E. pallida var pallida roots in which polyacetylenes are the major lipophilic compounds. In the same manner, composition variation also occurs in the hydrophilic fraction, for instance, while cynarin is exclusive of E. pallida var angustifolia roots, the CAD echinacoside, used to standardize E. pallida var angustifolia and E. pallida var pallida extracts is not found in E. purpurea aerial parts in which the CADs cichoric and 
caftaric acid are found in abundance (Bauer, 1999). These variations have a practical applicability as unique constituents can be used as marker compounds to enable identification of species and standardization of Echinacea products.

\subsection{Pharmacological findings - The purple flower power}

\subsubsection{Echinacea's immunomodulation and anti-inflamatory proprieties}

A number of studies have demonstrated a range of biological activities displayed by Echinacea preparations, including immunomodulation and anti-inflammatory activities, antioxidant, anti-viral and anti-fungal activities (Bauer, 2000; Hall and Schwarz, 2002; Barrett, 2003; Barnes et al., 2005), but undoubtedly, the most popular therapeutic application of Echinacea is as immunomodulator and anti-inflammatory agent, typically taken orally in the form of ethanolic extracts and tinctures to treat upper respiratory tract infections, which are for the most part the result of a viral infection causing inflammation. In an effort to establish the validity of these claims, ethanolic, chloroformic and aqueous extracts from all three commercial species of Echinacea (pallida, angustifolia and purpurea) have been examined. These fractions have been tested in vitro, ex-vivo and in vivo and found to have potential to stimulate immune cells activity. Increased phagocytic activity in murine and human polymorphonuclear neutrophils (PMNs) and induction of several inflammatory cytokine secretion by macrophages are among the most reported pharmacological effects of Echinacea extracts (Stimpel et al., 1984; Wagner et al., 1988; Bauer, 1999; Rininger et al., 2000; Barrett, 2003; Barnes, et al., 2005). 


\subsubsection{Echinacea's antioxidant properties}

The potential antioxidant activity of Echinacea has been the object of numerous in vitro studies. Facino et al. (1995) demonstrated that Echinacea protected collagen from free radical damage. In another study, $\mathrm{Hu}$ and $\mathrm{Kitts}$ (2000) found evidence of free radical scavenging activity in Echinacea root extracts with E. purpurea extracts showing the lowest antioxidant activity which led them to hypothesize that echinacoside was responsible for the antioxidant activity given that this CAD is lacking in E. purpurea extracts. In addition Dalby-Brown et al. (2005) have reported free radical scavenging activity in extracts of all three species of Echinacea in a study measuring protection of the human low density lipoproteins (LDL) from oxidation. Chicoric acid was considered as having the most antioxidant activity when compared with two other CADs (echinacoside and caffeic acid), and with alkamides and waterextracted polysaccharides. However, it was the mix of the three fractions (chicoric acid, alkamides and polysaccharides) that resulted in the highest percentage of antioxidant activity, indicating that the antioxidant effect of Echinacea extracts may be a consequence of a synergist effect of the three classes of compounds.

\subsubsection{Echinacea's antifungal properties}

Apart from numerous studies on the anti-inflammatory activity resulting from modulation of the immune system and subsequent increase in macrophage activation and phagocytosis, additional research has demonstrated that Echinacea extracts have direct antifungal activity. In a study by Binns et al. (2000), the hexane extract of commercial Echinacea preparations consisting of tinctures and tea of E. purpurea, and a mix of E. purpurea and E. angustifolia, and fresh plant parts from 
E. purpurea and E. pallida were assayed by disk susceptibility tests. These extracts were shown to have antifungal activity against $S$. cerevisiae and several Candida species, with some samples showing UVA-light-enhanced antifungal activitya phenomenon called phototoxicity (Towers et al., 1997). These observations may explain the antimicrobial properties of Echinacea in topical preparations. These antifungal activities were corroborated by Merali et al. (2003) where extracts from several varieties of E. pallida and E. atrorubens were tested against clinically important human pathogenic fungi.

The findings from these previously mentioned studies have led to further investigation into the mechanism of action of Echinacea's antifungal activity. In a study by Mir-Rashed and colleagues (2010), ethanolic extracts of aerial parts and roots of E. purpurea and E. angustifolia were assayed by gene deletion array (GDA) using a set of $\sim 4600$ deletion mutant strains of $S$. cerevisiae. Of the $\sim 4600$ mutants tested, twenty-three showed consistent evidence of hypersensitivity to Echinacea treatments. From this cluster of twenty-three, ten are known to be implicated in cell wall function, six are either related to transcription, protein or amino acid biosynthesis, and the remaining seven mutants are in genes with unknown function. The result of this study indicated that the basis for Echinacea's antifungal properties is by disruption of the fungal cell wall functions. Subsequently to these observations, other experiments designed to investigate the relationship between fungal exposure to Echinacea extracts and disruption of fungal cell wall function were carried out. A combination of exposure to Echinacea extracts and sonication followed by observation using florescence microscopy revealed an increased frequency in fungal 
cell death and cell wall damage resulted from treatment with Echinacea extracts. These cell wall assays supported the hypothesis, based on GDA results, that Echinacea extracts interfere with fungal cell wall functions.

\subsection{Echinacea's pharmacodynamics and mode of action studies}

As a result of the above mentioned findings, three groups of phytochemicals are considered to be relevant to the pharmacological activities of Echinacea extracts - caffeic acid derivatives (CADs), polysaccharides, and lipophilic alkamides (Bauer, 1999). Therefore, research is now being carried out to investigate the pharmacological effects and mechanism of action of these compounds in isolation and in combination. Still, as is the case with many herbal phytotherapics, the complexity of the extract composition makes it difficult to ascertain if the pharmacological effects of Echinacea preparations are caused by a specific compound, a class of compounds or are the result of the many constituents acting synergistically.

\subsubsection{Polysaccharides - Pharmacological findings}

Stimpel (1984) and Wagner (1988) have studied polysaccharides extracted and purified from E. purpurea and polysaccharides obtained from E. purpurea cell cultures and concluded that they induced macrophage production and activation. However it is very unlikely that polysaccharides play any role in the pharmacological activities of the commonly used Echinacea preparations as these compounds are not present in ethanolic extractions but they can't be ruled out as having pharmacological activity in topical applications. 


\subsubsection{Caffeic acid derivatives (CADs) - Pharmacological findings}

Of the several caffeic acid derivatives (CADs), chicoric acid-a major component of E. purpurea, is considered to be important to the immunomodulatory activity of Echinacea, given that, unlike echinacoside and other CADs, chicoric acid has been shown to stimulate phagocytosis in vitro (Bauer, 1999). However, caffeic acid conjugates have a very low bioavailability (Matthias et al., 2004; Matthias et al., 2005) and are therefore unlikely to be an important contributor to Echinacea's in vivo immunomodulating activity. Another characteristic of CADs that has been studied is the antioxidant nature of these compounds, which could have potential applications for the food industry and topical preparations. As mentioned above, Dalby-Brown et al (2005) have reported the highest free radical scavenging activity by chicoric acid when compared with all other CADs, and other fractions of Echinacea extracts.

\subsubsection{Alkamides - Pharmacological findings}

Alkamides are secondary metabolites widely distributed in plants. This large group of $\sim 200$ closely related unsaturated fatty acid amides are found in as many as ten plant families with the highest levels found in Asteraceae, Piperaceae and Rutaceae. Alkamides from Echinacea are isobutylamides of unsaturated fatty acids mostly derived from undeca and dodecanoic acids that differ by the length of the carbon chain, the degree of saturation, and position of saturated carbon bonds. Alkamides are found in small amounts in the aerial parts of E. purpurea and E. angustifolia but are abundant in the roots of these two species where they are the major constituents of the lipophilic fraction. A number of alkamides have been 
identified in Echinacea species, with the pair of isomers dodeca-2E, $4 \mathrm{E}, 8 \mathrm{Z}, 10 \mathrm{E} / \mathrm{Z}$ tetranoic acid isobutylamides, being the main alkamides found in ethanolic Echinacea preparations (Bauer et al., 1988a; Bauer et al., 1988b; Bauer et al., 1989; Binns et al., 2002). This pair is usually referred as the "tetraenes" in the literature. The molecular structure of the main alkamides from Echinacea are shown in Figure 3 (Woelkart and Bauer, 2007).

\subsubsection{Alkamide permeability to membranes and bioavailability}

In contrast to CADs, alkamides are reported to have a high bioavailability and they are readily detected in human plasma after only 15 to 20 min following ingestion, and remain detectable in the blood for up to 12 hours (Matthias et al., 2005; Woelkart et al., 2005a; Woelkart et al., 2008b). These findings make a strong case for the role of the alkamides as the main active principle in Echinacea phytotherapics that are taken orally. Interestingly, permeability studies in vitro using Caco-2 cell monolayer model (CMM), an intestinal barrier model (Matthias et al., 2004) and in vivo comparing plasma absorption kinetics of the different Echinacea alkamides found a correlation between the molecular structure of alkamides and their individual bioavailability (Matthias et al., 2004; Woelkart et al., 2005a; Woelkart and Bauer, 2007). Generally, the alkamides from Echinacea can be categorized into two groups: the 2,4-dienes and the 2-ene alkamides (Figure 3). In the Caco-2 (CMM) study, pairs of 2,4-dienes and equivalent 2 -ene alkamides were tested with results showing that the 2,4-dienes are more rapidly transported through the membrane compared to their equivalent 2-ene alkamides. In Matthias et al. (2004) study, the alkamide 2a, 
which is a 2,4-diene, showed twice the permeability of the alkamide 3a-its 2-ene correspondent alkamide. Similarly, the 2,4-diene alkamide 6 showed a $75 \%$ increase in relation to the 2 -ene alkamide 10 (Figure 4). In addition, the most lipophilic alkamide, the dodeca-2E,4E-dienoic acid-isobutylamide (Figure 4, alkamide 12), which does not have a terminal diene-diyene moiety (double and/or triple bonds at the end of the fatty acid chain), showed the lowest permeability in the Caco-2 CMM study and was below the detectable limit in the human pharmacokinetic studies, suggesting that there is a correlation between increase in unsaturation and increase in the permeability and bioavailability of the alkamides. Moreover, methylation in either terminal of the alkamides was shown to decrease the permeability of alkamides by close to $50 \%$ in the same Caco-2 CMM study (Figure 4). 
General Introduction: The chemical make up of a best seller

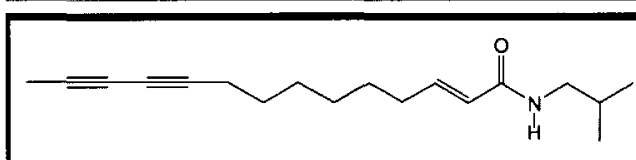

Alkamide 1. Tetradeca-2E-ene-10,12-diynoic acid isobutylamide

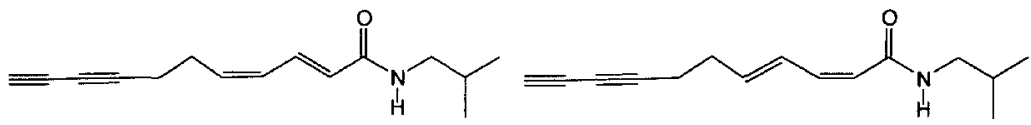

Alkamides $2 \mathrm{a} / 2 \mathrm{~b}$. Undeca-2E/Z,4Z/E-diene-8,10-diynoic acid isobutylamide

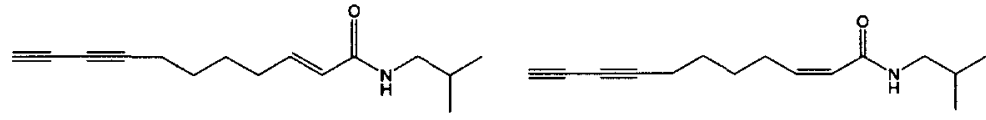

Alkamides 3a/3b. Undeca-2E/Z-ene-8,10-diynoic acid isobutylamide<smiles>CC#CC#CCC/C=C/C=C/C(=O)NCC(C)C</smiles>

Alkamide 4. Dodeca-2E,4Z-diene-8,10-diynoic acid isobutylamide<smiles>CC#CC#CCCC=CC=CC(=O)NCC(C)CC</smiles>

Alkamide 6. Dodeca-2E,4Z-diene-8,10-diynoic acid 2-methylbutylamide

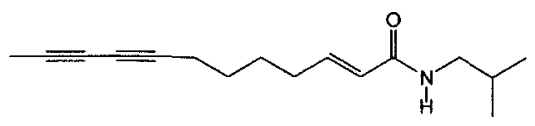

Alkamide 5. Dodeca-2E-ene-8,10-diynoic acid isobutylamide<smiles>CCC#CCC/C=C/C=C/C(=O)NCC(C)C</smiles>

Alkamide 7. Dodeca-2E,4Z,10Z-triene-8diynoic acid isobutylamide

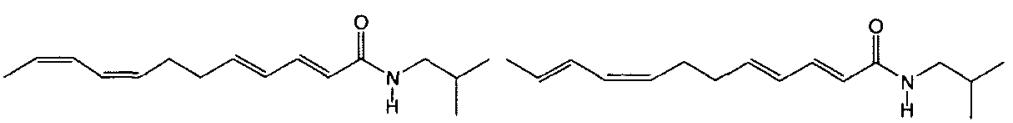

Alkamides $8 \mathrm{a} / 8 \mathrm{~b}$. Dodeca-2E,4E, $8 \mathrm{Z}, 10 \mathrm{E} / \mathrm{Z}$-tetraenoic acid isobutylamide - "Tetraenes"<smiles>C#CC#CCC=CCCCCCC=CC(=O)NCC(C)C</smiles>

Alkamide 9. Pentadeca-2E,9Z-diene-12,14-diynoic acid isobutylamide<smiles>CCC/C=C\CC/C=C/C=C/C(=O)NCC(C)C</smiles>

Alkamide 11. Dodeca-2E,4E,8Z-trienoic acid isobutylamide<smiles>CC#CC#CCC=CCCCCCCC=CC(=O)NCC(C)C</smiles>

Alkamide 13. Hexadeca-2E,9Z-diene12,14-diynoic acid isobutylamide

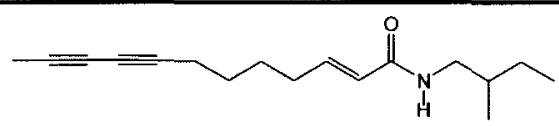

Alkamide10. Dodeca-2E-ene-8,10-diynoic acid 2-methylbutylamide<smiles>CCCCCCCC/C=C/C=C/C(=O)NCC(C)C</smiles>

Alkamide 12. Dodeca-2E,4E-dienoic acid isobutylamide<smiles>C#CC#CCCC/C=C/C(=O)NCC(C)CC</smiles>

Alkamide 14. Undeca-2Z-ene-8,10-diynoic acid 2-methylbutylamide<smiles>C#CC#CCC/C=C/C=C/C(=O)NCC(C)CC</smiles>

Alkamide 15. Undeca-2E,4Z-diene-8,10diynoic acid 2-methylbutylamide

Figure 3. Chemical names and molecular structures of the main alkamides from Echinacea (Woelkart and Bauer, 2007). 
<smiles>C#CC#CCC/C=C/C=C/C(=O)NCC(C)C</smiles>

Alkamide 2a: Undeca-2E,4Z-diene-8,10-diynoic acid isobutylamide. Apparent permeability (Papp) twice of the 2-ene correspondent alkamide $3 a$.<smiles>C#CC#CCCCC/C=C/C(=O)NCC(C)C</smiles>

Alkamide 3a: Undeca-2E-ene-8,10-diynoic acid isobutylamide.<smiles>CC#CC#CCC/C=C/C=C/C(=O)NCC(C)C</smiles>

Alkamide 4: Dodeca-2E,4Z-diene-8,10diynoic acid isobutylamide. Methylation on diynoic terminal decreases permeability by $45 \%$ when compared with alkamide $2 a$.<smiles>CC#CC#CCCCC/C=C/C(=O)NCC(C)CC</smiles>

Alkamide10: Dodeca -2E-ene-8,10-diynoic acid 2-methylbutylamide. Methylation on both ends decreases permeability by $65 \%$ when compared with alkamide $3 a$.<smiles>CCCCCCC/C=C/C=C/C(=O)NCC(C)C</smiles>

Alkamide 12: Dodeca-2E,4E-dienoic acid isobutylamide. The most lipophilic alkamide tested showed the lowest permeability in the Caco-2 CMM study.

Figure 4. Structures of some of the alkamides tested in the Caco-2 CMM study by Matthias et al. (2004), illustrating the correlation between molecular structure and ability to cross membranes. 


\subsubsection{Alkamides immunomodulation and anti-inflammatory activities}

As is the case with CADs, early research demonstrated that purified alkamide fractions from Echinacea extracts have immunomodulatory and anti-inflamatory activities. Studies applying carbon clearance tests and measurement of inflammatory cytokines revealed enhanced phagocytic activity and induction of macrophage activity by alkamides from E. purpurea and E. angustifolia. Intriguingly however, the most abundant of the alkamides, the pair of isomers dodeca-2E, $4 \mathrm{E}, 8 \mathrm{Z}, 10 \mathrm{E} / \mathrm{Z}$ tetranoic acid isobutylamides (tetraenes), showed little evidence of immunomodulatory activity in these early studies, suggesting that a minor alkamide or a combination of alkamides may be responsible for the Echinacea immunomodulatory effects (Bauer, 1999; Matthias et al., 2007). In another study of the anti-inflammatory potential of alkamides, Cech et al. (2010) reported that the "tetraenes" and other alkamides show an ability to suppress the production of several inflammatory cytokines and chimokines from RAW macrophage-like cells infected with influenza A virus thus corroborating the anti-inflammatory activity of alkamides from Echinacea.

\subsubsection{Alkamides - Mode of action studies}

Alkamides have been found to inhibit cyclooxygenase (COX-1/COX-2) and 5-lipoxygenase (5-LOX). These two are key enzymes in the arachidonic acid metabolism pathway to prostaglandins, thus the search for compounds with dual inhibition activity, and more specifically COX-2/5-LOX, is a new strategy in the non-steroidal anti-inflamatory drugs (NSAIDs) research. Müller-Jakic et al. (1994) studied the inhibition of COX (using the sheep seminal vesicles model) and 5-LOX (using porcine leukocytes) by n-hexane extract of E. angustifolia roots and twenty 
alkamides isolated from several varieties of Achillea, Anacyclus, Aaronsohnia and E. angustifolia. Müller-Jakic reported that while the root extract inhibited both enzymes, most alkamides inhibited only COX and just a few had an effect on 5-LOX. Confirmation of 5-LOX inhibition by root extracts of the three commercial species of Echinacea was reported by Merali et al. (2003). In another study, Clifford et al. (2002) investigated the potential selective inhibition of COX-1/COX-2 by alkamides isolated from E. purpurea roots in comparison with the following anti-inflammatory drugs: aspirin, ibuprofen, naproxen, celecoxib (Celebrex ${ }^{\mathrm{TM}}$ ) and rofecoxib (Vioxx $\mathrm{x}^{\mathrm{TM}}$ ). Selective COX-2 inhibition is a desirable characteristic in anti-inflammatories as inhibition of COX-1 is known to cause more adverse reactions when compared with inhibition of COX-2. This study revealed that several alkamides showed COX-1 and COX-2 inhibition, but not a selective inhibition of COX-2, and that the "tetraenes" (the most abundant alkamides) isolated from E. purpurea did not show any measurable inhibitory activity for either COX-1 or COX-2. Interestingly, the same compounds isolated from E. angustifolia showed a 54\% inhibition of COX (Muller-Jakic et al., 1994). In a more recent study by Hinz et al. (2007), $\mathrm{CO}_{2}$ extracts from $E$. angustifolia roots and eight isolated alkamides and were tested with human neuroglioma cells for their ability to inhibit the enzymatic activity of COX-2 and that of COX-2 mRNA and protein expression. In this study, the $\mathrm{CO}_{2}$ root extract and three of the eight alkamides tested inhibited COX-2 activity, yet none of the alkamides inhibited COX-2 protein expression. Again, the "tetraenes" were practically inactive, showing no inhibition of the COX-2 activity. Therefore more studies are needed to determine weather or not the inhibition of COX activity by alkamides is the mechanism of action for Echinacea anti-inflammatory effect. 


\subsubsection{Alkamides and anandamine - the "bliss" molecule \\ Alkamides are structurally similar to the endogenous cannabinoid anandamine - The "bliss" molecule}

Another proposed molecular mechanism to explain the alkamides antiinflammatory properties is gaining prominence after the publication of several findings reporting the ability of alkamides to bind to the cannabinoid receptors $\mathrm{CB} 1$ and $\mathrm{CB} 2$ which are known to modulate inflammation (Woelkart et al., 2005b; Raduner et al., 2006; Matovic et al., 2007; Chicca et al., 2009). The CB1 receptor was first reported by Devane et al (1988) and is found predominantly in the central nervous system. The CB2, on the other hand, is a peripheral subtype of cannabinoid receptor found in the spleen and immune-competent cells (Munro et al., 1993). $\mathrm{CB}$ receptors are thought to be responsible for the wide range of effects observed when delta 9-tetrahydrocannabinol (delta 9-THC), a major constituent of Cannabis sativa, binds to them (for a review see Howlett et al., 2004). Not much longer after the discovery of the CB1-receptor, Devane et al. (1992) reported the identification of a potent endogenous cannabinoid ligant: the arachidonylethanolamide (Figure 5). Termed anandamine from the Sanskrit word for "bliss" ananda, anandamine is a fatty-acid derived compound with pharmacological effects similar to delta 9-THC (Devane et al., 1992).

Interestingly, alkamides are structurally similar to the anandamine (Figure 5) and as such, interact with CB-receptors as agonists mimicking the action of cannabinoid ligants such anandamine. Raduner et al., (2006) and Woelkart et al., (2005b) have reported the results of a radioligand displacement assays on $\mathrm{CB} 1$ and 
$\mathrm{CB} 2$ receptors in which alkamides were shown to bind to $\mathrm{CB}$-receptors and more selectively to $\mathrm{CB} 2$-receptors, in concentrations similar to that found in human plasma after Echinacea intake. Therefore, it is reasonable to infer that a similar in vivo binding of alkamides with $\mathrm{CB} 2$ receptors in immuno-competent cells might occur thus triggering immune and anti-inflammatory responses.

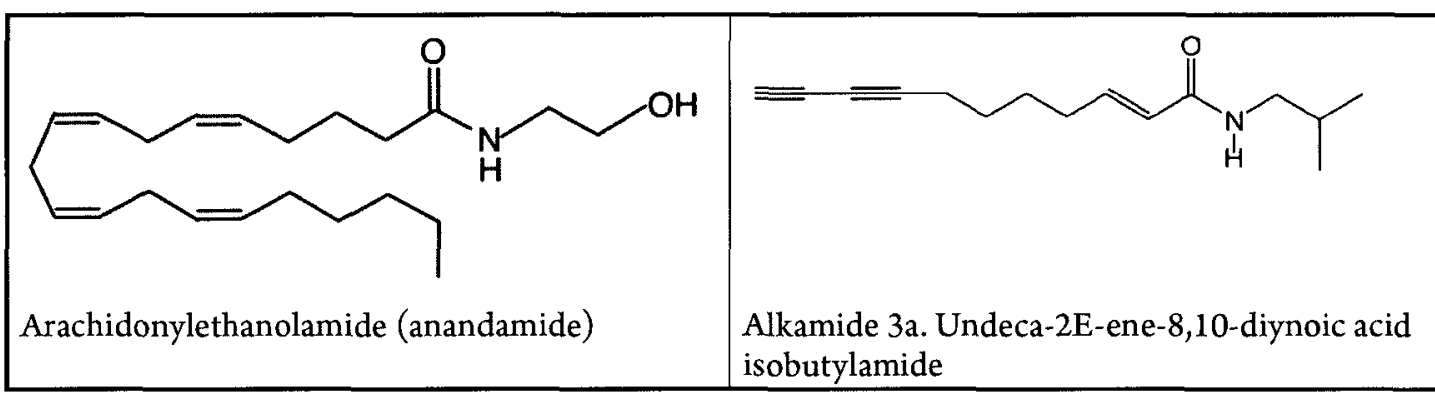

Figure 5. Molecular structure of the endocannabinoid anandamide and alkamide 3a.

Given that the enzymes COX and 5-LOX, and CB2 receptors play a significant role in the molecular pathways of the inflammation process, it is reasonable to conclude that, even though there are clear differences in the effectiveness of each alkamide, this class of compounds may be clinically useful to reduce pain and inflammation, which would be in agreement with the traditional use of Echinacea (Bauer, 2000; Clifford et al., 2002; Hinz et al., 2007). 


\section{The Aim of This Present Work}

As a consequence of the many new insights into the pharmacodynamics and mode of action of Echinacea and its constituents, particularly of the alkamides, there is a renewed interest in the study of the purple coneflower that grows peacefully in backyards everywhere, oblivious to all the scientific commotion surrounding it.

Encouraged by the results of the previously referenced experiments indicating that Echinacea affects fungal cell wall function (Mir-Rashed et al., 2010), I proposed to test the hypothesis that the antifungal mode of action of Echinacea extracts is through cell wall disruption by alkamides. Therefore, the aim of this research is:

1. Test if alkamides in Echinacea extracts have antifungal activity.

2. Develop a cell wall disruption assay to screen natural-derived compounds with potential to be further developed into new antifungal pharmaceuticals.

3. Test if alkamides have cell wall disruption activity.

4. Compare the cell wall disruption activity of different alkamides.

5. Develop a general QSAR model to study lipophilicity-antifungal activity relationships in alkamides. 


\section{Materials and Methods}

The key procedural steps in the assay we developed to detect yeast cell wall damage are summarized in Figure 8. Experimental details for each step are given in the following sections.

\subsection{Yeast strains and growth conditions}

\subsubsection{S. cerevisiae wild type S288C and cell wall mutant YMR307W}

The two Saccharomyces cerevisiae strains used in this study were the wild type S288C (MATa SUC2 mal mel gal2 CUP1 flo1 flo8-1 hap1) and the cell wall mutant YMR307W (GAS1). GAS1 encodes 1,3- $\beta$-glucanosyltransferase, a GPI-anchored protein localized to the extracellular face of the plasma membrane and is involved in the remodeling of $\beta$-1,3-glucan after its synthesis by $\beta$-glucan synthase at the membrane (Mouyna et al., 2000). A gas1 null mutant has a weakened cell wall with cells abnormally round and multi-budded, with reduced viability, increased sensitivities to some cell wall-affecting drugs and elevated temperatures (Marx et al., 2006; SDG project., 2008). Chitin synthesis is upregulated in gas1 mutants to compensate for defective $\beta$-1,3-glucan (Popolo et al., 1997; Ram et al., 1998; Mouyna et al., 2000). Moreover, strain YMR307W has been previously shown to be sensitive to Echinacea extracts in a study by Mir-Rashed et al. (2010) that showed that yeast strains with deletions of genes that have a cell wall function are highly susceptible to growth inhibition by Echinacea extracts. 


\subsubsection{Growth conditions}

These strains are maintained in YPD broth (2\% glucose, $2 \%$ peptone, $1 \%$ yeast extract) with glycerol $(25 \%)$ at $-80^{\circ} \mathrm{C}$ in the Biology Department at Carleton University, Ottawa ON Canada. Working cultures were inoculated from glycerol stocks to minimal synthetic complete (SC) medium [2\% glucose (BDH, Toronto, Canada), $0.67 \%$ yeast nitrogen base without amino acids (Becton, Dickson and Co, Sparks, MD)] with or without $2 \%$ agar (Bioshop Canada, Burlington ON)] and supplemented with required amino acids (Sigma-Aldrich, Oakville, ON) as described in Gietz (1996).

\subsection{Test compounds sources}

\subsubsection{Echinacea purpurea}

Echinacea purpurea (L.) Moench plants were organically-grown in Ottawa, Ontario. Echinacea roots were rinsed in tap water, oven dried overnight at $50^{\circ} \mathrm{C}$, and milled to $<1 \mathrm{~mm}$ (Thomas-Wiley Model 4 Mill, Arthur H. Thomas Co., Philadelphia, PA). Dried root material (40.6 g) was extracted three times with $\sim 400 \mathrm{~mL}$ of $70 \%$ ethanol at room temperature for $24 \mathrm{~h}$ with moderate agitation. The resulting three extracts were filtered through Whatman \#1 paper, pooled, and concentrated by rotaryevaporation (900-100 rpm, 850-900 mbar) and freeze-drying for $24 \mathrm{~h}$. The resulting crude extract (6.68 g) was analysed by HPLC (Figure 6) and stored in the dark at $-20^{\circ} \mathrm{C}$ for up to 2 months or until use. 


\subsubsection{Synthetic alkamides}

Natural alkamides are present in the roots of Echinacea purpurea and are believed to be responsible for some of the pharmacological properties of Echinacea preparations (Woelkart and Bauer, 2007; Mir-Rashed et al., 2010). The synthetic alkamides used in this study listed in Table 1 were synthesized as described previously (Matthias et al., 2004; Matovic et al., 2007) and kindly donated by Dr. R. P. Lehmann from the MediHerb Research Laboratories, Queensland, Australia. Weighed quantities of alkamides were resuspended in $70 \%$ ethanol and stored in the dark at $-80^{\circ} \mathrm{C}$ until use.

\subsubsection{Antifungal controls}

Caspofungin acetate (CAS, Figure 7-A) was kindly provided by Merck \& Co. (Rahway, NJ) and was used as a positive control in our experiments. CAS is the first FDA approved member of the echinocandin class of antifungals. It inhibits the synthesis of a major fungal cell wall component, $\beta$-1,3-glucan, and thus disrupts cell wall integrity (Kartsonis et al., 2003). Two aminoglycosidic antibiotics, hygromycin B (HYG, Figure 7-B, Roche Applied Science, Mannheim, Germany) and nourseothricin dihydrogen sulfate (clonNAT, Figure 7-C, WERNER BioAgents, Jena, Germany), were used as negative controls as their mode of action is not related to cell wall stability but, rather, inhibition of protein synthesis. 


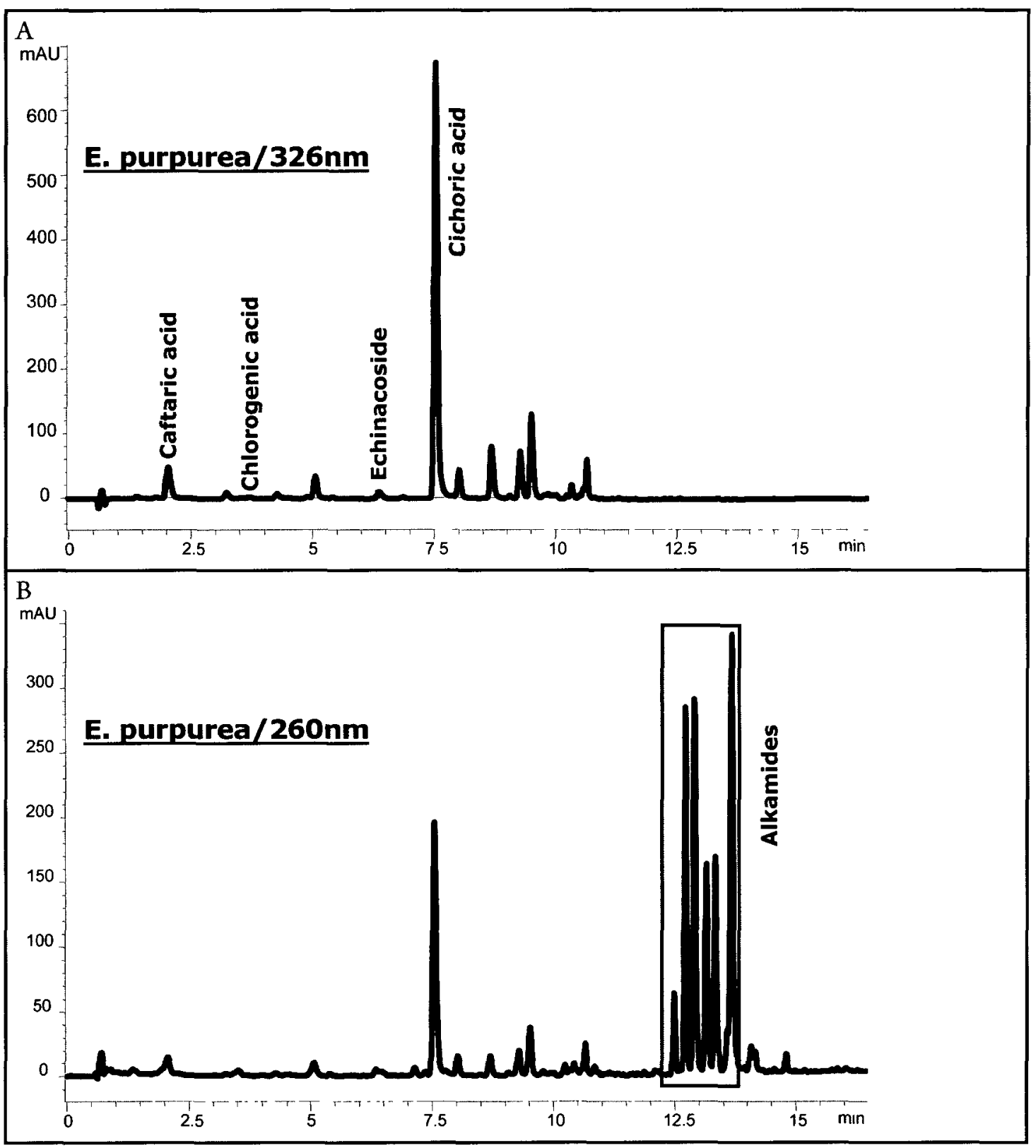

Figure 6. HPLC profile of the E. purpurea extract used in the study showing UV absorbance vs. retention time. Panel A: Detection at $326 \mathrm{~nm}$. The major phenolic compounds are indicated. Panel B: Detection at $260 \mathrm{~nm}$ showing the typical HPLC profile of alkamides from Echinacea extracts. Test conditions: Column: YMC ODS-AM (12) $100 \mathrm{~mm} \times 2 \mathrm{~mm}$ ID. [YMC-9] Oven $50 \mathrm{C}$; flow rate $0.5 \mathrm{~mL} / \mathrm{min}$. Solvents: $A=$ Water+ TFA $0.05 \%$. $B=\mathrm{MeCN}+$ TFA $0.05 \%$. 
Table 1. Synthetic alkamides used in this study. The seven alkamides were synthesized and kindly donated by Dr. R. P. Lehmann from the MediHerb Research Laboratories, Queensland, Australia.

\begin{tabular}{l|l|l}
\hline Alkamides molecular structures & $\begin{array}{l}\text { Code } \\
\text { Name }\end{array}$ & $\begin{array}{l}\text { Chemical Name and } \\
\text { Molecular Weight }\end{array}$ \\
\hline $\begin{array}{l}\text { Alk2b } \\
\text { Undeca-2Z,4E-diene-8,10-diynoic } \\
\text { acid isobutylamide } \\
\text { MW=229.32 }\end{array}$ & $\begin{array}{l}\text { Undeca-2E-ene-8,10-diynoic } \\
\text { acid isobutylamide } \\
\text { MW=231.34 }\end{array}$ \\
\hline
\end{tabular}




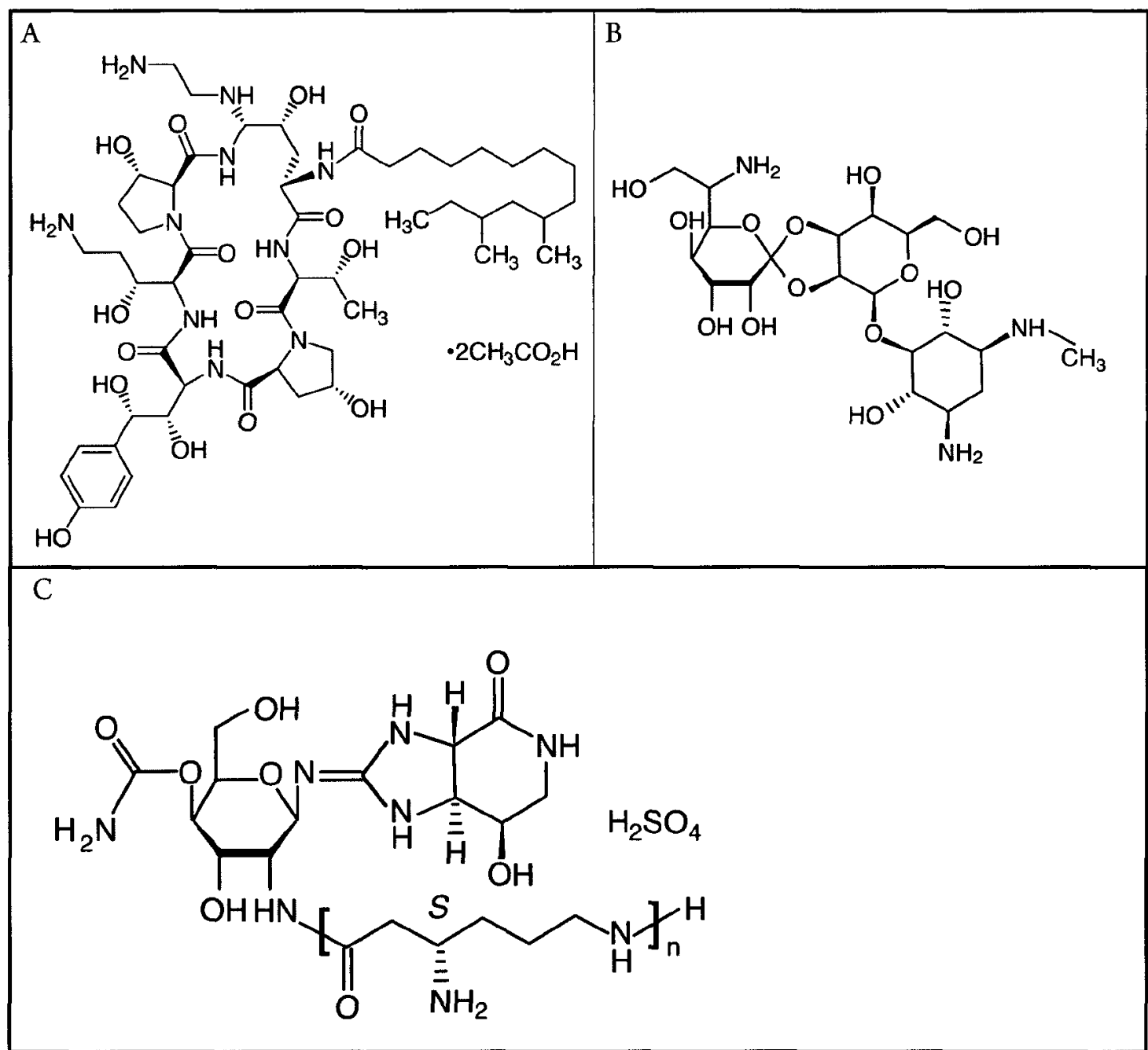

Figure 7. Antifungal controls used in this study. Panel A: Biochemical structure of caspofungin (Kartsonis et al., 2003). Panel B: biochemical structure of hygromycin $B$ (from product insert). And Panel C: biochemical structure of nourseothricin dihydrogen sulfate (from manufacturer web site ("WERNER BioAgents"). Nourseothricin consists of the three homologue streptothricins: F, $n=1(61 \%), E, n=2$ (7\%) and $\mathrm{D}, \mathrm{n}=3,(31 \%)$. 


\subsection{Antifungal susceptibility assays}

\section{Identification of optimal test compound concentration}

\subsubsection{Minimum inhibitory concentration (MIC) - Microdilution broth assay}

All antifungal compounds used in this study were tested to determine their minimum inhibitory concentration (MIC) by a microdilution broth assay, based on methods described previously (Rex et al., 1993; Rex et al., 2001; Ficker et al., 2003). Briefly, yeast strains were incubated overnight at $30^{\circ} \mathrm{C}, 150 \mathrm{rpm}$ in SC medium and then diluted to obtain a cell density of $\sim 10^{5} \mathrm{CFU} / \mathrm{mL}$. The culture was distributed into each microplate well (round bottom, sterile 96-well microplates, Diamed, Mississauga, ON, Canada) except for the last column, which served as a contamination control for media and test compounds. Test or control compounds were added to the first well of each row and serially diluted $1.5 \mathrm{X}$ across the columns. The last column of each row was left as compound free control. The concentration of each compound used in the first well in the serial dilution was determined to be in the inhibition range by preliminary tests. Hygromycin B was used as positive antifungal control in all MIC experiments. The microplates were examined visually after stationary incubation at $30^{\circ} \mathrm{C}$ for $72 \mathrm{~h}$. The MIC values were recorded as the lowest tested concentration that resulted in an optically clear well. The MIC assays were performed independently at least three times for each fungal strain/compound combination to derive the mean MIC. The inhibitory effect of the test compounds expressed as minimum inhibitory concentration (MIC) are summarized in Table 2. 


\subsubsection{MIC $40 \%$ inhibition-Drop plate method}

The drop plate assay was based on the method described by Chen et al (2003) and it was used to estimate percentage of growth inhibition induced by test compound treatments and reduction in cell viability after sonication. Preliminary assays were done using 20, 40 and $60 \%$ of the MIC values determined as described in 3.3.1. Based on the results of these preliminary assays, a $40 \%$ MIC concentration was chosen as the optimal for the fluorescent microscopy assay. Briefly, yeast cells were 10 times serially diluted with fresh medium in a 96-well microplate. Using a multichannel pipette, $10 \mu \mathrm{L}$ drops were spotted on agar medium at concentrations of $\sim 10^{4}, 10^{3}, 10^{2}, 10$ cell $/ 10 \mu \mathrm{L}$, and colony forming units (CFU) were determined after incubation for $36-48 \mathrm{~h}$ at $30^{\circ} \mathrm{C}$. Drop plate assays were done in triplicate. Percentage of growth inhibition was calculated as the ratio of $\mathrm{CFU} / \mathrm{mL}$ of treated/non-treated samples. Based on this assay, test compound concentrations were established that caused a growth inhibition of $40 \pm 5 \%$ compared to the no-inhibitor control.

\subsection{Fluorescent microscopy assay}

\subsubsection{Treatment with test compounds}

Each yeast strain tested was inoculated from a late exponential phase pre-culture in SC medium and allowed to recover to a mid-log phase by overnight incubation at $30^{\circ} \mathrm{C}$ and $150 \mathrm{rpm}$. Before proceeding with the assay, the cell density was adjusted to $\sim 10^{7}$ cell $/ \mathrm{mL}$ using a hemocytometer, and a $10 \mu \mathrm{L}$ aliquot was removed for drop plate assay. The resulting CFU counting of this first aliquot was used to calculate the percentage of growth inhibition after the yeast cell exposure 
to test compounds. At this point, volumes of $0.4 \mathrm{~mL}$ of the cell culture were transferred to $1.5 \mathrm{~mL}$ sterile microcentrifuge tubes, the test compounds were added at a sub-inhibitory concentration equivalent to $\sim 40 \%$ of the MIC and the same volume of carrier control $(70 \% \mathrm{EtOH})$ was added to a non-treated control sample. The cells were incubated at $30^{\circ} \mathrm{C} / 150 \mathrm{rpm}$ for about $4 \mathrm{~h}$ and subjected to sonication treatment as described below.

\subsubsection{Ultrasound treatment - Mild sonication}

The protocol used in this study to treat yeast cell with mild sonication was adapted from Ruiz et al. (1999). After the $4 \mathrm{~h}$ exposure to the test compounds, an aliquot of $90 \mu \mathrm{L}$ was transferred from each tube to a new microcentrifuge tube and set aside as the non-sonicated control. The remaining cells were sonicated on ice for $2 \mathrm{~min}$ ( $3 \mathrm{~mm}$ microtip probe, $20 \%$ amplitude, pulse $15 \mathrm{~s}$, interval $3 \mathrm{~s}$ ) using a Vibra Cell sonicator (Vibra Cell VCX130. Sonic \& Materials, Connecticut, USA). After sonication, all samples (non-sonicated and sonicated) were drop plate assayed, the remaining cells were pelleted by low speed centrifugation $(2000 \mathrm{rpm}, 2 \mathrm{~min})$, the supernatant was removed and the cells were resuspended in fresh medium and immediately observed by fluorescent microscopy as described below.

\subsubsection{Fluorescence microscopy}

Yeast cell suspensions were stained by applying $2 \mu \mathrm{L}$ of a solution of $0.1 \%$ (w/v in distilled water) calcofluor white M2R (American Cyanamid, Bound Brook, NJ) and $0.1 \%$ Evans Blue (Fisher Scientific CO., Limited, Toronto, ON, Canada) to $10 \mu \mathrm{L}$ of cell suspension on a microscope slide. A coverslip was gently applied before observation. Microscopic observations were made with an Axio Imager fluorescence 
microscope (Carl Zeiss, Toronto, ON) using 40X and 100X objective lenses. Using the multidimensional acquisition feature in the Axio Imager it was possible to obtain multiple fluorescence channel images using the DAPI filter to detect calcofluor fluorescence - a blue-white will be observed staining the fungal cell walls--and Rhodamine filter to detect Evans Blue fluorescence-visualized as a white-reddish/ pink fluorescence in cells with loss of metabolic activity. Images were captured with the Zeiss AxioVision software (Carl Zeiss MicroImaging GmbH, German) in the Carl Zeiss ZVI proprietary image format. The original images were saved unprocessed and copies of the original files were processed with Image J (Wayne Rasband, National Institutes of Health, USA) and transferred to Photoshop (Adobe Systems Inc., San Jose, California) for manual enumeration and further analyses.

\subsubsection{Statistical analyses}

The experiment was repeated at least three times for each compound tested and approximately 1000 cells were examined from 5 to 8 randomly selected fields for each of the three replicate treatments for a total of $\sim 3000$ cell observations per compound. Cells were evaluated for cell wall damage and viability, counted and classified in each of four groups: cell wall damaged (CWD), Evans Blue positive (EB+), budded/multibudded (BMB) and single non-divided daughter cells (S) (Figure 9). This data set was plotted in Excel (Microsoft Corporation, Redmond, WA, USA) as a percentage of the total number of cells enumerated. Mean values and the standard error of the mean (SE) were also calculated using Excel. The statistical analysis of the experimental data was done by analysis of variance (ANOVA) with a post-hoc Tukey HSD test $(\alpha=0.05)$ using JMP (v8.0.2, SAS Institute Inc, Carry, NC, USA). 


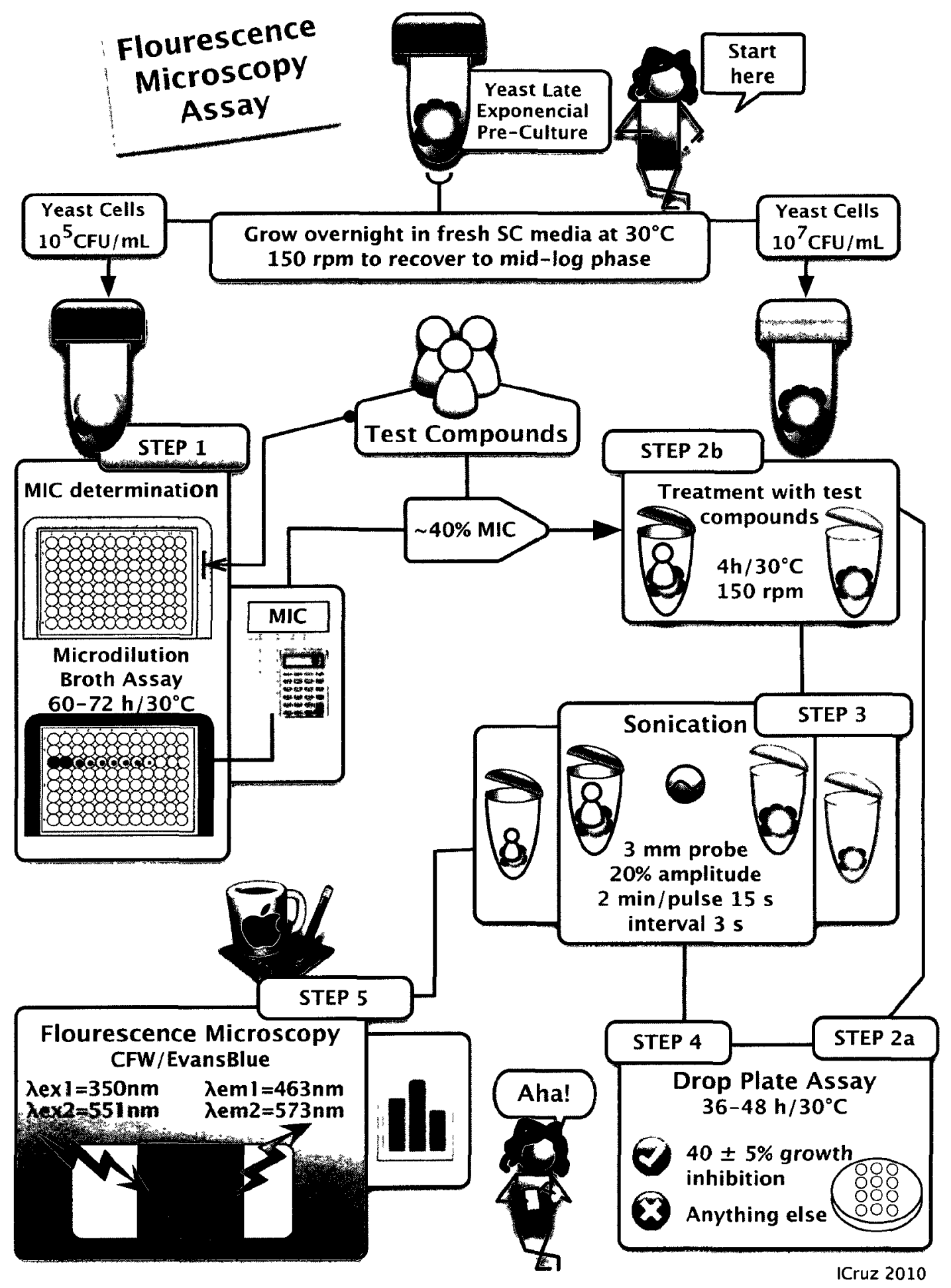

Figure 8. The figure above is a schematic diagram illustrating the several steps of the protocol for the fluorescent microscopy assay used in this study. 

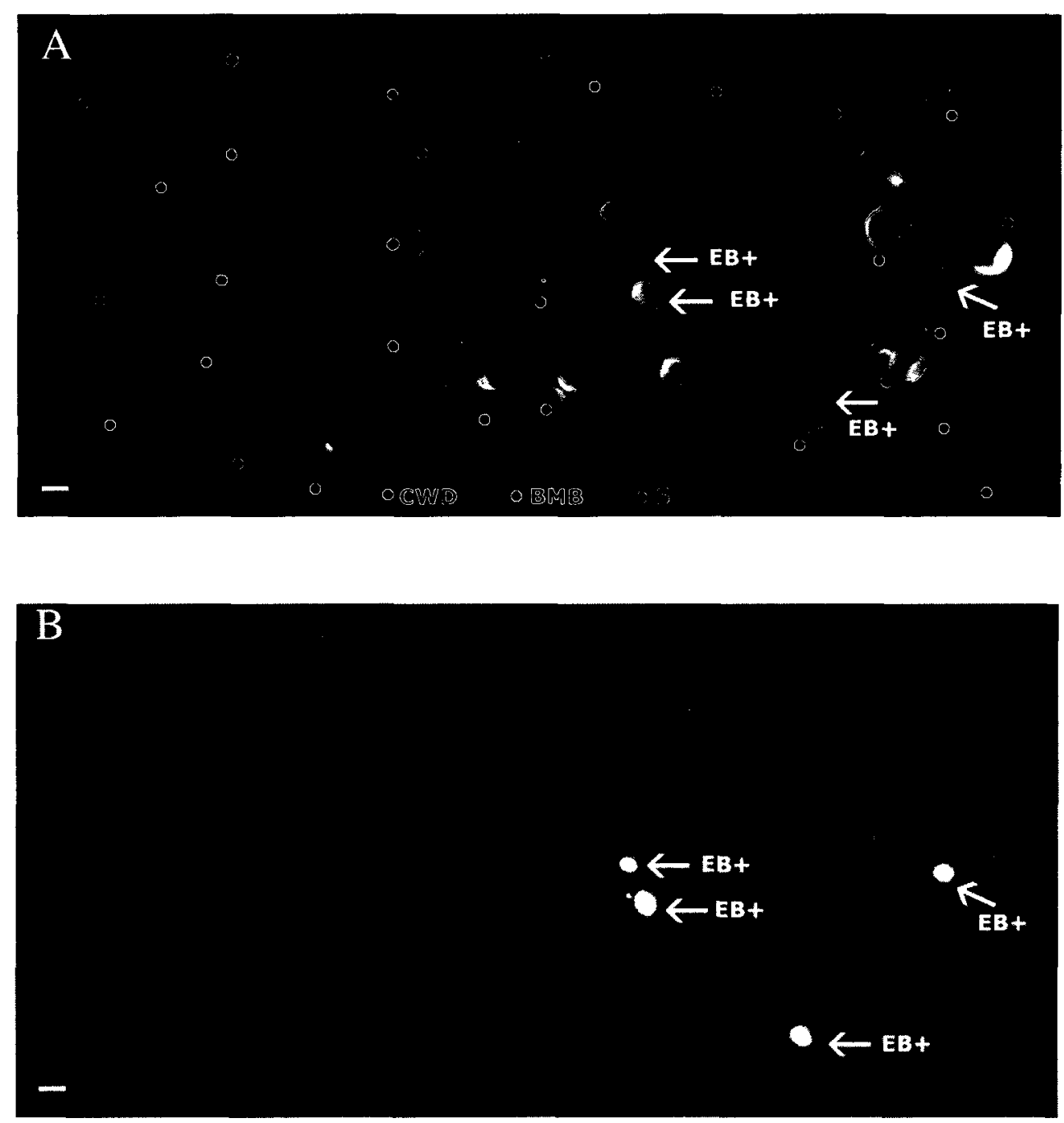

Figure 9. Fluorescent microscopy images of S. cerevisiae S288C cells after treatment with Echinacea extract followed by sonication. Image A shows the S288C cells stained with Calcofluor White/Evans Blue as seen with the DAPI filter set and image B shows the same microscopic field as seen with the Rhodamine filter set $(\mathrm{bar}=5 \mu \mathrm{m})$. CWD (red dots)=cell wall damaged; $\mathrm{EB}+$ (white arrows)=Evans Blue positive; BMB (light blue dots)=budded/ multi-budded and $S$ (blue dots)=single non-divided daughter cells. 


\subsection{Alkamides QSAR modeling}

\section{A general QSAR model to study lipophilicity-antifungal activity relationships in alkamides from Echinacea}

Quantitative structure-activity relationships (QSAR) models are based on the premise that the biological activity of a compound is the consequence of its chemical structure and that this relationship can be predicted through a mathematical expression (for a review of the history of QSAR, see Selassie, 2003). The QSAR paradigm can be expressed in mathematical terms as:

$$
\Delta \text { biological activity }(\mathrm{BA})=f(\Delta \mathrm{x} 1+\Delta \mathrm{x} 2+\ldots+\Delta \mathrm{xn})
$$

Where (BA) could be $\mathrm{LD}_{50}, \mathrm{MICs}$, etc...; and $\mathrm{xl}, \ldots$, $\mathrm{xn}$ are mathematical descriptors of key properties of molecular structures relevant to the biologic activity being studied.

A classic QSAR modeling technique is the Hansch analysis. First developed by Hansch and Fujita (Fujita and Hansch, 1967; Hansch et al., 1968) more than 40 years ago. Hansch's approach correlates the logarithm of octanol-water partition coefficient $(\log$ P), a molecular descriptor of lipophilicity, with a biological activity expressed as $\log 1 / C$ were $C$ is the molar concentration of a compound producing a standard biologic response. Many QSAR linear model equations were postulated since QSAR modeling inception and after extensive evaluation of linear models Hansch and coworkers (Hansch and Clayton, 1973) showed that QSAR equations relating biologic activity $(\log 1 / C)$ and lipophilicity $(\log \mathrm{P})$ are more often than not a parabolic equation, leading to the postulation of the parabolic model equation formally expressed as follows: 


$$
\log 1 / C=a(\log P) 2+b \log P+c
$$

Where $\log \mathrm{P}=$ the value of the lipophilicity descriptor for each molecule in the series and where each letter $a, b$ and $c$, represents a coefficient calculated by fitting variations in the data by regression analysis using the least square method.

A classic Hansch QSAR modeling (Hansch et al., 1968; Hansch and Clayton, 1973) was adopted to further study the role of the alkamides chemical structure and lipophilicity in influencing the antifungal activity of these molecules. The development of a QSAR model involves three key steps:

a) Collecting a data set of experimental measurements of a biological activity for a group of analog compounds.

b) Converting the molecular structures of the analog compounds into mathematical descriptors.

c) Using regression analysis and statistical methods to find relationship between the two data sets.

In the QSAR model developed here, $\log \mathrm{P}$ was calculated for each alkamide and in an Hansch-model fashion plotted against the logarithm of $1 / C(\log 1 / C)$, were $C$ is the molar concentration of a compound producing a standard biologic response. In our case the biological activity is the antifungal properties of alkamides expressed as the molar concentration that causes $\sim 40 \%$ growth inhibition determined as described in 3.3.2. Once the descriptors are determined and plotted the next step in QSAR modeling is to perform multiple regression analyses by the least squares method to find the best fit for the curve and the statistical parameters to evaluate the reliability of the model. A more detailed description of the methodology follows. 
3.5.1. Calculation of the alkamide descriptors $(\log P)$ and biologic activity $(\log 1 / C)$

Free online tools were used to generate the data for the QSAR modeling. The SMILES (simplified molecular input line entry system) notation for the alkamides were created using the structure drawing application JME molecular editor available at Molinspiration Cheminformatics website (JME, 2011).

The $\log \mathrm{P}$ for each alkamide was obtained by inputting the SMILES notation in another free online tool, ALOGPS 2.1 from Virtual Computational Chemistry Laboratory (VCCLAB, 2011). Several online programs are available to calculate the lipophilicity of a compound based on their structure. The decision to use ALOGPS program was based on the ability of the application to simultaneously displays $\log$ P values calculated with several algorithms (ALOGPS 2.1, Pharma Algorithms LogP, Actelion $\log \mathrm{P}$, Molinspiration $\log \mathrm{P}$, KOWWIN $\log \mathrm{P}, \mathrm{ALOGP}$, MLOGP, XLOGP2 and XLOGP3 $\log$ P calculators) and automatically calculate the average $\log \mathrm{P}$ and standard deviation. Therefore by using ALOGPS 2.1 tool it was possible to compare the results of several algorithms with one click. As for the biologic activity measurement $(\log 1 / C)$, it was calculated as the logarithm of the inverse of the alkamide molar concentration that caused a growth inhibition of $40 \pm 5 \%$ compared to the no-inhibitor control, the MIC40\% as established in 3.3.2.

\subsubsection{Regression Analysis and model's goodness-of-fit evaluation}

The average of alkamides $\log$ P generated by the ALOGPS 2.1 tool were plotted against the $\log 1 / C$ and the curve fitting and statistical analysis of quality of the resulting model was done using GraphPad PRISM ${ }^{\circledR}$ version 5, GraphPad Software, 
San Diego California USA, www.graphpad.com; and the free online curve fitting tool ZunZun Online Curve Fitting and Surface Fitting Web Site (ZunZun, 2011). The correlation coefficient $\mathbf{r}^{2}$ was used as measure of the quality of fit of the model. 


\section{Results and Discussion}

\subsection{Intra and inter-assay controls}

\subsubsection{Minimum inhibitory concentration (MIC) determination}

In the first step of this study, the S. cerevisiae strains wild type S288C and cell wall mutant YMR307W were initially tested for their susceptibility to a range of concentrations of the following test compounds: caspofungin (CAS), hygromicin B (HYG), nourseothricin (clonNAT) (Figure 7); Echinacea crude extract (Figure 6); and seven synthetic alkamides from Echinacea (Table 1). A broth microdilution technique was used to assess the strains susceptibility to the test compounds as described in the materials and methods section. Briefly, overnight cultures (cell density of $\sim 10^{5} \mathrm{CFU} / \mathrm{mL}$ ) of $\mathrm{S} 288 \mathrm{C}$ and YMR307W strains were inoculated in 96 -well microplates and incubated at $30^{\circ} \mathrm{C}$ with the test compounds serially diluted $1.5 \mathrm{X}$ across the columns for $60 \mathrm{~h}$ for strain S288C and $72 \mathrm{~h}$ for strain YMR307W. The microplates were examined visually and MIC values were recorded as the lowest tested concentration that resulted in an optically clear well. The inhibitory effect of the test compounds expressed as minimum inhibitory concentration (MIC) are summarized in Table 2. From this the concentration was determined at which the yeast strains had $40 \%$ growth inhibition.

\subsubsection{Validating $40 \%$ growth inhibition}

The quantification of cell viability by the drop plate assay described in the materials and methods section was used for quality assurance purposes, as means to validate that each compound was tested at a concentration that, when compared 
with the non-treated control, would produce $\sim 40 \%$ growth inhibition during the $4 \mathrm{~h}$ incubation (MIC 40\%). Thus, each experiment was standardized to an intra and interassay control. The results of MIC 40\% determinations are shown in Table 2.

The concentration of each compound and the associated percentage of inhibition after 4 hour incubation at $30^{\circ} \mathrm{C}$ with strains $\mathrm{S} 288 \mathrm{C}$ and YMR307W is shown in Figure 10. Overall, these two yeast strains displayed similar inhibition profiles where the cell wall mutant YMR307W was generally more sensitive to inhibition by the tested compounds except for caspofungin.

Of the seven alkamides tested, the undeca-2Z,4E-diene-8,10-diynoic acid isobutylamide (henceforth referred as alk2b) required a significantly lower concentration to attain a $40 \%$ growth inhibition (Figure 10 ). Of note, alk $2 \mathrm{~b}$ was more effective than the two tested dodeca-2E,4E,8Z,10E/Z-tetraenoic acid isobutylamides "tetraenes", alk8E and alk8Z. As indicated in Table 3 , alk 2 b represents $\sim 18 \%$ of the total alkamides in the roots of E. purpurea (Wills and Stuart, 1999), while the tetraenes alk8E and alk $8 \mathrm{Z}$ are the most abundant of the root alkamides, accounting for $43-49 \%$ of the total (Kim et al., 2000). Also impressive was the efficacy of the undeca-2E-ene-8,10-diynoic acid isobutylamide (henceforth alk3a) to inhibit yeast growth. Although this alkamide is almost undetectable in the roots of all Echinacea species tested by Binns et al. (2002), alk3a tended to be the second most potent inhibitor of yeast cell growth of those alkamides tested (Figure 10). 
Table 2. Minimum inhibitory concentrations (MIC) results for the several test compounds used in this study. MIC40\%=Minimum $40 \%$ inhibitory concentration; $\log 1 / \mathrm{C}=\log$ arithm of the inverse of $\mathrm{MIC} 40 \%$ in $\mathrm{mol} / \mathrm{L} ; \mathrm{ECH}=$ Echinacea extract; Alk2b to Alk12=alkamides (Table 1); CAS=Caspofungin; HYG=Hygromycin B; $\mathrm{NAT}=$ Nourseothricin, $\mathrm{BMM}=$ broth microdilution method $\mathrm{DPM}=$ Drop plate method

\begin{tabular}{|c|c|c|c|c|c|c|c|}
\hline \multirow{2}{*}{\multicolumn{2}{|c|}{ Test Compound }} & \multicolumn{6}{|c|}{ Strain } \\
\hline & & \multicolumn{3}{|c|}{ S288C } & \multicolumn{3}{|c|}{ YMR307W } \\
\hline & UNIT & $\begin{array}{c}\text { MIC } \\
\text { BMM }\end{array}$ & $\begin{array}{c}\text { MIC } 40 \% \\
\text { DPM }\end{array}$ & $\begin{array}{l}\log 1 / C \\
(\mathrm{~mol} / \mathrm{L})\end{array}$ & $\begin{array}{c}\text { MIC } \\
\text { BMM }\end{array}$ & $\begin{array}{c}\text { MIC } 40 \% \\
\text { DPM }\end{array}$ & $\begin{array}{l}\log 1 / \mathrm{C} \\
(\mathrm{mol} / \mathrm{L})\end{array}$ \\
\hline \multirow{2}{*}{$\mathrm{ECH}$} & $\mu \mathrm{g} / \mu \mathrm{L}$ & 143 & 58 & & 118 & 47.25 & \\
\hline & $\mathrm{mol} / \mathrm{L}$ & & & & & & \\
\hline \multirow{2}{*}{ Alk2b } & $\mu \mathrm{g} / \mu \mathrm{L}$ & 0.35 & 0.152 & & 0.22 & 0.087 & \\
\hline & $\mathrm{mol} / \mathrm{L}$ & & 0.00066 & 3.179 & & 0.00038 & 3.421 \\
\hline \multirow{2}{*}{ Alk3a } & $\mu \mathrm{g} / \mu \mathrm{L}$ & 0.59 & 0.218 & & 0.26 & 0.111 & \\
\hline & $\mathrm{mol} / \mathrm{L}$ & & 0.00094 & 3.026 & & 0.00048 & 3.319 \\
\hline \multirow{2}{*}{ Alk5 } & $\mu \mathrm{g} / \mu \mathrm{L}$ & 0.81 & 0.310 & & 0.52 & 0.210 & \\
\hline & $\mathrm{mol} / \mathrm{L}$ & & 0.00126 & 2.898 & & 0.00086 & 3.068 \\
\hline \multirow{2}{*}{ Alk8E } & $\mu \mathrm{g} / \mu \mathrm{L}$ & 0.62 & 0.260 & & 0.30 & 0.125 & \\
\hline & $\mathrm{mol} / \mathrm{L}$ & & 0.00105 & 2.978 & & 0.00051 & 3.296 \\
\hline \multirow{2}{*}{ Alk8Z } & $\mu \mathrm{g} / \mu \mathrm{L}$ & 0.65 & 0.271 & & 0.30 & 0.131 & \\
\hline & $\mathrm{mol} / \mathrm{L}$ & & 0.00110 & 2.960 & & 0.00053 & 3.276 \\
\hline \multirow{2}{*}{ Alk1 1} & $\mu \mathrm{g} / \mu \mathrm{L}$ & 0.89 & 0.340 & & 0.62 & 0.255 & \\
\hline & $\mathrm{mol} / \mathrm{L}$ & & 0.00136 & 2.865 & & 0.00102 & 2.990 \\
\hline \multirow{2}{*}{ Alk12 } & $\mu \mathrm{g} / \mu \mathrm{L}$ & 0.89 & 0.329 & & 0.62 & 0.254 & \\
\hline & $\mathrm{mol} / \mathrm{L}$ & & 0.00130 & 2.885 & & 0.00101 & 2.997 \\
\hline \multirow{2}{*}{ CAS } & $\mu \mathrm{g} / \mathrm{mL}$ & 0.15 & 0.061 & & 0.40 & 0.140 & \\
\hline & $\mathrm{mol} / \mathrm{L}$ & & & & & & \\
\hline \multirow{2}{*}{ HYG } & $\mu \mathrm{g} / \mu \mathrm{L}$ & 0.51 & 0.215 & & 0.25 & 0.108 & \\
\hline & $\mathrm{mol} / \mathrm{L}$ & & & & & & \\
\hline \multirow{2}{*}{ NAT } & $\mu \mathrm{g} / \mu \mathrm{L}$ & 0.015 & 0.006 & & 0.007 & 0.003 & \\
\hline & $\mathrm{mol} / \mathrm{L}$ & & & & & & \\
\hline
\end{tabular}



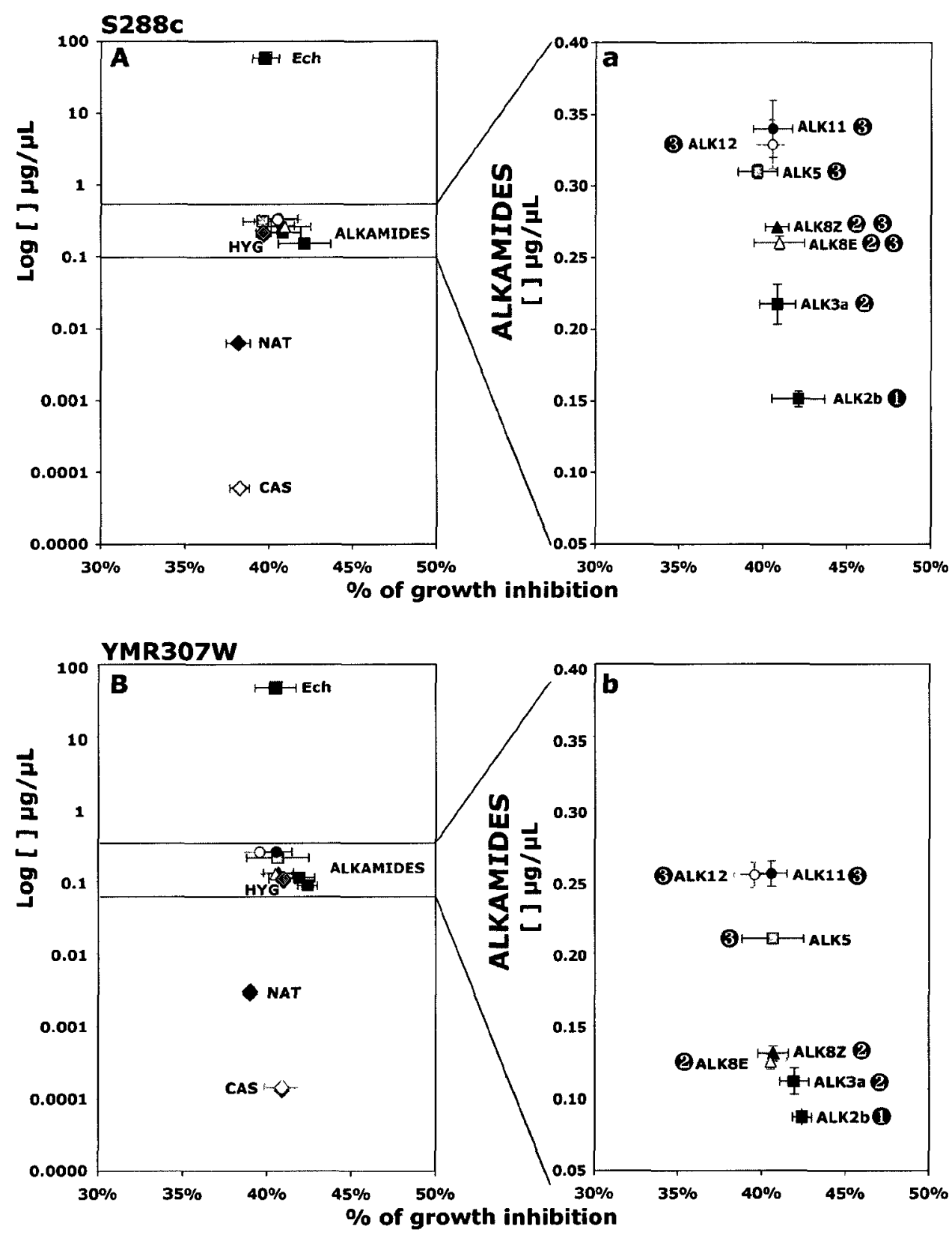

Figure 10. Compound concentration required during 4 hour exposure to achieve $\sim 40 \%$ growth rate inhibition. Data points represent the means $( \pm S E, n \geq 3$ ) for both compound concentration and percent inhibition. Panels $a$ and $b$ are a blow-up of the alkamides results in panels A (wild type S288C) and B (strain YMR307W). Concentrations that achieve $\sim 40 \%$ inhibition of alkamides that are designated by the same colored digit are not significantly different (ANOVA, Tukey HSD, $\alpha=0.05$, $\mathrm{P}<0001)$. 
Table 3. Alkamide concentrations found in Echinacea purpurea roots as reported by several studies.

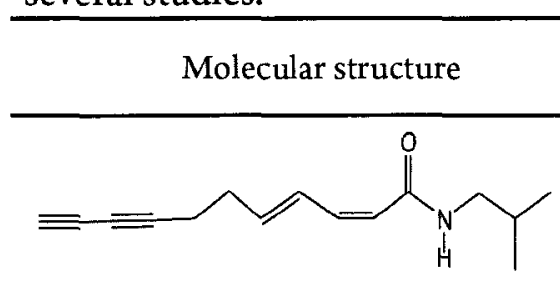

Undeca-2Z,4E-diene-8,10-diynoic acid isobutylamide<smiles>C#CC#CCCCCC/C=C/C(=O)NCC(C)C</smiles>

Undeca-2E-ene-8,10-diynoic acid isobutylamide<smiles>CC#CC#CCCCCC=CC(=O)NCC(C)C</smiles>

Dodeca-2E-ene-8,10-diynoic acid isobutylamide<smiles>C/C=C/C=C\CC/C=C/C=C/C(=O)NCC(C)C</smiles>

Dodeca-2E,4E,8Z,10E-tetraenoic acid isobutylamide<smiles>C/C=C\C=C/CC/C=C/C=C/C(=O)NCC(C)C</smiles>

Dodeca-2E,4E,8Z,10Z-tetraenoic acid isobutylamide

\begin{tabular}{c|c}
$\begin{array}{c}\text { Code } \\
\text { name }\end{array}$ & \\
& \\
Alk2b &
\end{tabular}

\begin{tabular}{|c|c|c|}
\hline $\begin{array}{c}\text { Concn } \\
(\mathrm{mg} / \mathrm{g})\end{array}$ & $\begin{array}{c}\text { Total Alk } \\
\text { Concn }(\mathrm{mg} / \mathrm{g})\end{array}$ & Source \\
\hline
\end{tabular}

$2.13 \pm 1.08^{a}$

Data not

North America wild harvested a

New Zealand ${ }^{c}$

\section{Alk3a}

$0.02 \pm 0.02 \mathrm{a}$

Data not available

North America wild harvested ${ }^{a}$<smiles>CCC/C=C\CC/C=C/C=C/C(=O)NCC(C)C</smiles>

Alk5

0.00 -traces a

Data not available

North America wild harvested a

.
isobutylamide<smiles>CCCCCCCC/C=C/C=C/C(=O)NCC(C)C</smiles>

Dodeca-2E,4E-dienoic acid isobutylamide

a Binns et al., 2002
b Bauer and Reminger, 1989
c Perry et al., 1997

d Kim et al., 2000

e Wills and Stuart, 1999 


\subsection{Measuring yeast cell wall disruption by fluorescence microscopy}

\subsubsection{Yeast cell wall disruption by ultrasound-induced cavitation}

Ultrasound-induced cavitation is an established method of physically disturbing yeast cell wall and membranes (Miller et al., 1996; Ciccolini et al., 1997; Mir-Rashed et al., 2010). The premise of the method is that yeast cells that are exposed to a compound that disrupts cell wall function(s) are expected to be more sensitive to mild sonication than cells that are not exposed to the compound. In my studies, yeast cells having cell wall damage were easily identified using the light microscopy methods (Figure 11). The extent of cell wall damage observed can be related to the cell wall disrupting ability of a given test compound. In the case of Evans Blue stained cells, on the other hand, this correlation might not be so clear at first glance as the cells look intact. However, a functional intact membrane is vital to keep Evans Blue from staining the cell cytoplasm, therefore these cells are clearly struggling to keep the dye from staining the cytoplasm, which might be an indication of difficulties in the cell wall/membrane complex function(s) caused by the treatment with the test compounds.

The several types of cell wall damage observed, as well as how the yeast cells and cell wall damage appear when stained with CFW and Evans Blue under the filters (DAPI/Rhodamine) are exemplified in Figure 11. It is interesting to note how cells apparently intact (appHC) in the DAPI field can be stained by Evans Blue (Figure 11; A,B). 

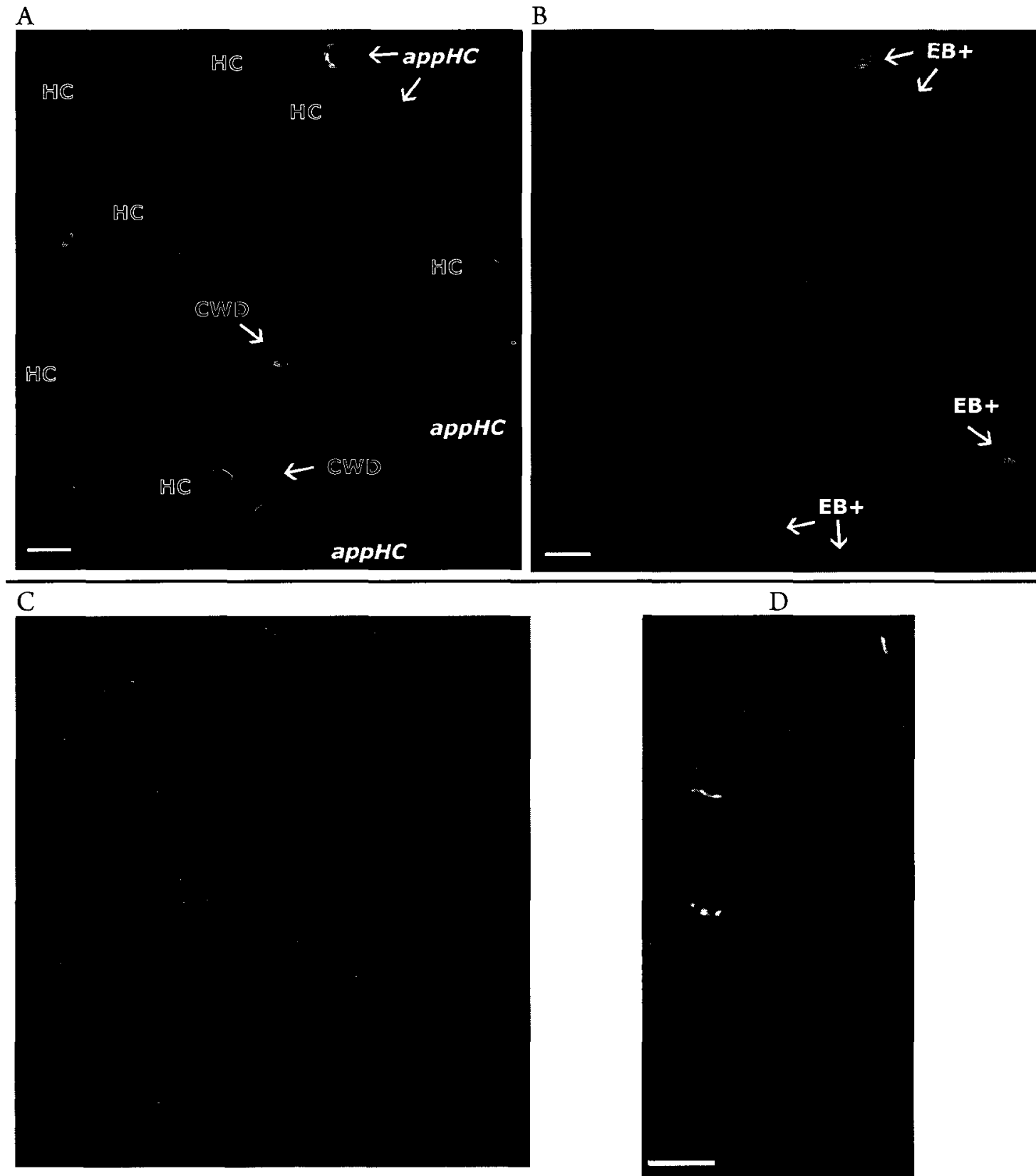

D

Figure 11. Wild type $S 288 \mathrm{C}$ yeast cells were treated with Echinacea extract for 4 hours prior to sonication and then simultaneously stained with CFW and Evans Blue immediately before examination with fluorescence microscopy. Micrographs were taken using the DAPI (Panel A) and Rhodamine, (Panel B) filters (100x magnification, bar $=5 \mu \mathrm{m}$ ). Panel $\mathrm{C}$ shows a superimposition of panels $\mathrm{A}$ and $\mathrm{B}$. $\mathrm{HC}=$ Healthy Cell, appHC=apparently Healthy Cell, CWD=Cell Wall Damage, EB+ =Evans blue stained. Panel D (bar $=5 \mu \mathrm{m})$ displays some of he several types of cell wall damage observed in this study using CFW staining, ranging from small defects to complete collapse of cell structure. 


\subsection{Cell wall damage and loss of viability observations}

\subsubsection{Untreated Control}

Percentage of cell wall damage (CWD) and

frequency of Evans Blue stained cells (EB+)

Untreated control cells that were not subjected to sonication $(-T / S)$ showed very little evidence of cell wall damage (CWD) or loss of viability (EB+). This was true for both tested strains, wild type S288C and the cell wall mutant strain YMR307W. For both strains, less than $1.5 \%$ of the yeast cells were Evans Blue-positive $(\mathrm{EB}+)$, a proxy for dead or non-viable cells, and less than $0.15 \%$ had noticeable cell wall damage (CWD) based on CFW staining (Figures 12, 13, 14 and Tables 2 and 3) - a good indication that the general health of the yeast cell suspension have not been compromised during the several stages of the assay.

\section{Untreated Control - Baseline effect of sonication}

Untreated control cells that were subjected to sonication $(-T /+S)$ showed some cell wall damage ( $11-12 \%)$ and some decrease in cell viability (less than $15 \%$ ) (Figures 14 and 15, Tables 4 and 5). This data indicates that with the mild sonication protocol used, cell wall damage and loss of viability occurs to some extent whether or not the cells were subjected to a prior treatment with a compound that disrupts cell wall function(s). In view of this, it is reasonable to expect that the degree of cell wall damage and loss of viability on treated samples subjected to sonication $(+\mathrm{T} /+\mathrm{S})$ should be equal or greater than values observed in the $(-T /+S)$ controls. 


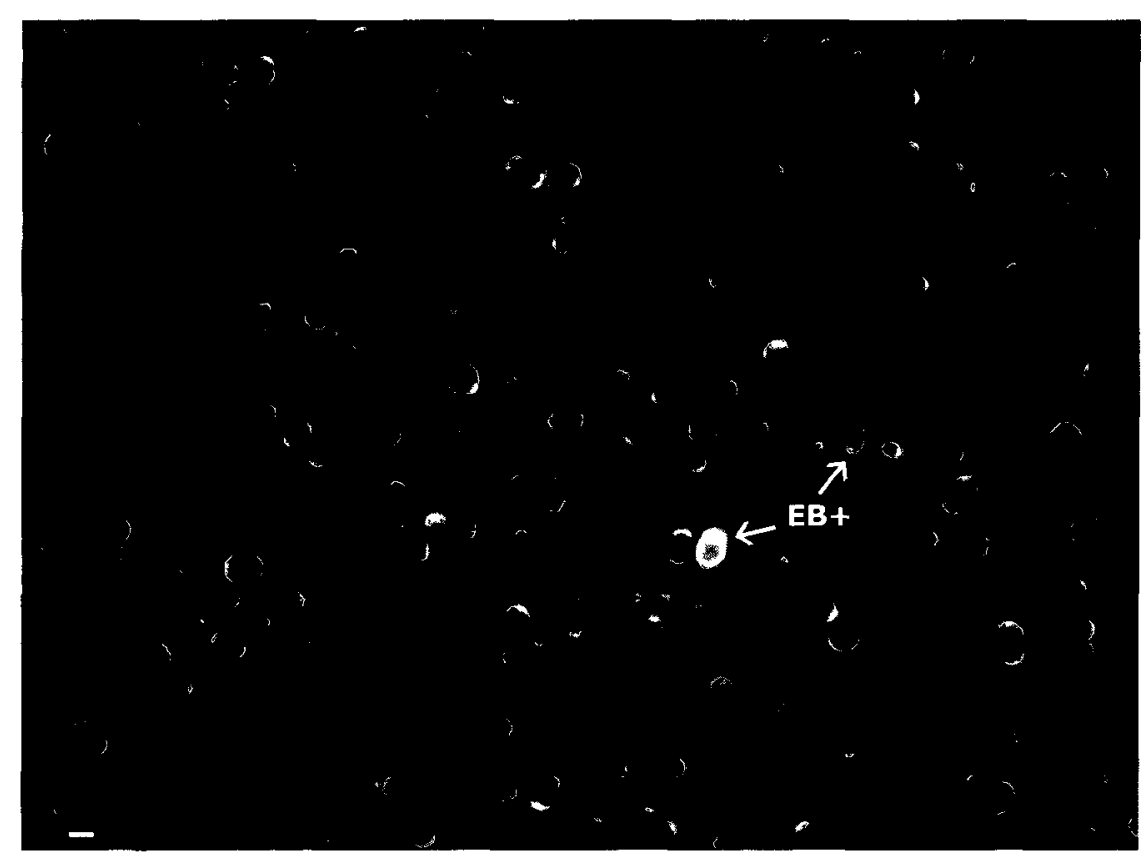

A) $\mathrm{S} 288 \mathrm{C} \mathrm{CTR}(-\mathrm{T} / \mathrm{S}) \mathrm{CFW} / \mathrm{DAPI}$ filter

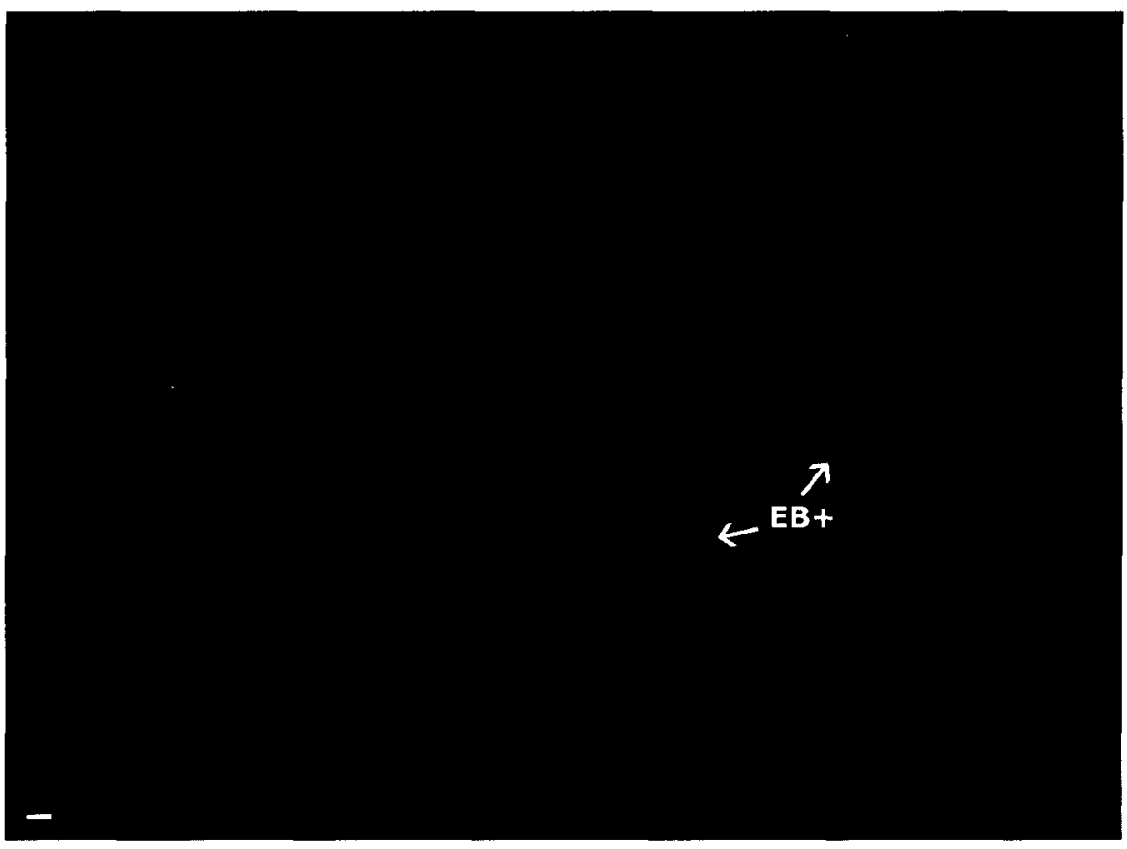

B) S288C CTR (-T/-S) EB/Rhodamine filter

Figure 12. Fluorescence microscopy images (40x magnification, bar $=5 \mu \mathrm{m}$ ) of S. cerevisiae S288C untreated control cells with no sonication (-T/-S). No evidence of cell wall damage is observed (panel A: CFW/DAPI filter), nor significant loss of viability (panel B: EB/Rhodamine filter), which can be considered a good indication of the healthy state of the yeast cells. 


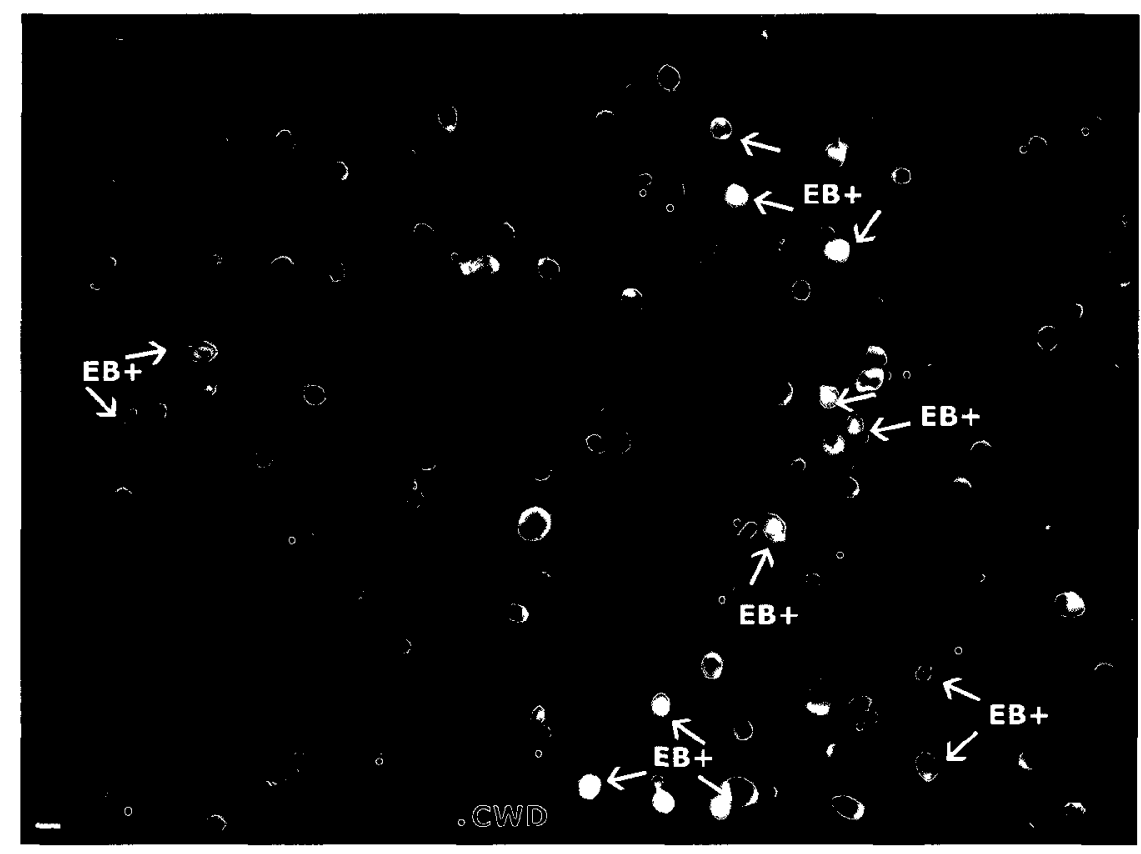

C) $\mathrm{S} 288 \mathrm{C} \mathrm{CTR}(-\mathrm{T} /+\mathrm{S}) \mathrm{CFW} / \mathrm{DAPI}$

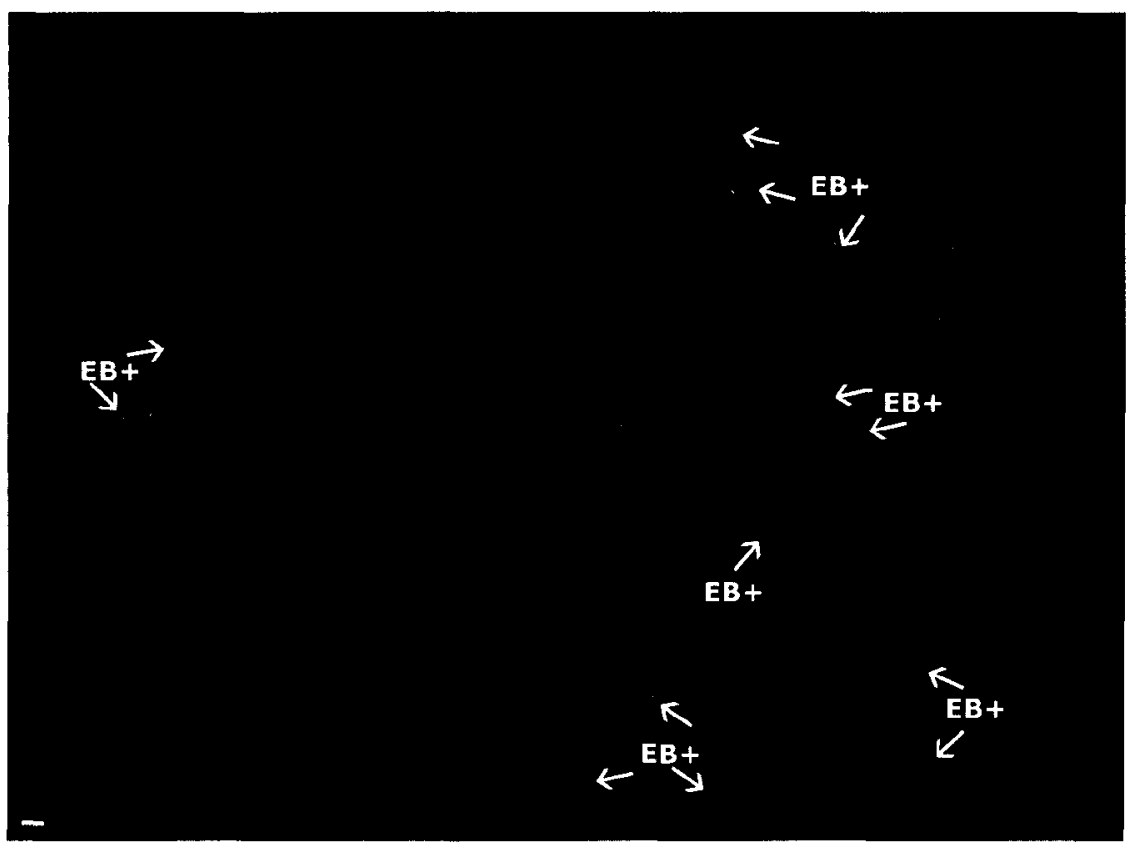

D)S288C CTR (-T/+S) EB/Rhodamine

Figure 13. Fluorescence microscopy images of $S$. cerevisiae $S 288 \mathrm{C}$ untreated control cells subjected to sonication $(-T /+S)$. Some cell wall damage (CWD-red dots) can be seen on panel C (CFW/DAPI filter) as well as some loss of viability (panel D: EB/ Rhodamine filter), illustrating the baseline effect of the mild sonication protocols used in this study (bar $=5 \mu \mathrm{m}$ ). 


\subsubsection{Negative Controls}

\section{Compounds with no known direct effect on cell wall function}

The compounds hygromicin B (HYG) and nourseothricin (clonNAT) are both classified as aminoglycoside antibiotics that primarily interfere with protein synthesis (Cabañas et al., 1978; Brodersen et al., 2000; Dembitsky, 2005; McGaha and Champney, 2007). Neither compound is reported to have direct negative effects on cell wall function(s) and were therefore selected in this study as negative control compounds for cell wall inhibition.

Percentage of cell wall damage (CWD), frequency of

Evans Blue stained cells and loss of viability $(E B+)$

The two negative controls showed similar results to that of the untreated control cells in both strains tested. The percentage of cell wall damage (CWD) observed in the non-sonicated cells treated with either HYG (hygT/-S) or clonNAT (natT/-S) was low for both the wild type S288C $(\leq 0.02 \%)$ and the cell wall mutant YMR307W $(\leq 0.09 \%)$. These values are not statistically different from the control (-T/-S) values of $0.14 \%$ and $0.07 \%$ for S288C and YMR307W, respectively. This indicates that exposures to either HYG or clonNAT does not cause cell wall damage in the strains tested (Figure 14, Tables 4 and 5). Similarly, cell wall damage in the negative control sonicated groups (hygT/ $+S$ and nat $\mathrm{T} /+\mathrm{S}$ ) were not significantly different from the non-treated sonicated controls; all were in the range of $11-13 \%$ $(-\mathrm{T} /+\mathrm{S})$. (Figure 15, Tables 4 and 5$)$.

Likewise, under the conditions used in this study, treatment with either HYG or clonNAT alone or accompanied by sonication, does not result in increased 
frequency of Evans Blue (EB+) stained cells in comparison with non-treated controls (Figures 14 and 15 and Tables 4 and 5). These observations validate the use of HYG and clonNAT as suitable negative controls for this study; they both inhibit cell proliferation but, under the experimental conditions used here, neither is associated with altered cell wall sensitivity to sonication.

\subsubsection{Positive Control}

\section{Caspofungin, a $\beta-1,3-$ glucan synthase inhibitor}

Caspofungin (CAS) was the first of a new class of antifungals, the echinocadins, to be approved for clinical use to treat invasive candidiasis and aspergillosis (Kartsonis et al., 2003). Recent studies with S. cerevisiae indicate that the products of gene FKS1 and its paralog FKS2 are the probable targets of caspofungin (Agarwal et al., 2003; Lesage et al., 2004; Markovich et al., 2004). These two genes encode subunits of the $\beta$-1,3-glucan synthase complex, a key enzyme in the synthesis of $\beta-1,3$-glucan. Polymers of $\beta$-1,3-glucan and $\beta-1,6$-glucan constitute $\sim 60 \%$ of the cell wall dry mass with $\beta-1,3$-glucan accounting for $85 \%$ of the total cell wall glucan. Moreover, $\beta$-1,3-glucan is the major structural component of the yeast cell serving as a scaffold for other molecules to attach and providing the mechanical strength of the cell wall (Klis et al., 2002). As a result of caspofungin interfering with these proteins the synthesis of $\beta-1,3$-glucan is inhibited and the integrity of the yeast cell wall is compromised. Therefore, it is reasonable to anticipate that, when compared with a non-treated control, treatment of yeast cells with caspofungin will make the yeast cell wall more susceptible to damage by sonication. 
As expected, the percentage of $\mathrm{CWD}$ in the cas $\mathrm{T} / \mathrm{S}$ treatment group was significantly greater than that observed in the control groups $(-T /+S)$ with both strains (Figure 15). The percentage of CWD observed in the wild type S288C was $20.9 \%$ and $23.4 \%$ in the YMR307W mutant in contrast with the respective $(-\mathrm{T} /+\mathrm{S})$ control values of $12.2 \%$ and $11 \%$ (Tables 4 and 5). In addition, the results for the caspofungin treated non-sonicated (casT/-S) wild type $S 288 \mathrm{C}$ show a significantly greater percentage of CWD than the non-treated control (-T/-S). This is an indication that even at the relatively low concentration used in this study, set to achieve a $\sim 40 \%$ growth inhibition, caspofungin causes significantly more CWD $(0.80 \%)$ than the $-\mathrm{T} / \mathrm{S}$ control $(0.14 \%)$ and all other test compounds (Figure 15).

Contrary to the wild type S288C, the percentage of CWD in the YMR307W casT/-S group $(0.24 \%)$ was not statistically different from the percentage of CWD $(0.07 \%)$ observed in the $-\mathrm{T} / \mathrm{S}$ control (Figure 15 ) suggesting a decreased sensitivity to the effects of caspofungin by this mutant. This increased resistance to caspofungin by YMR307W when compared with the wild type S288C was also noted early on in this study using minimum inhibitory concentration (MIC) assays in which $\operatorname{MIC}(\mathrm{S} 288 \mathrm{C})=0.15 \mu \mathrm{g} / \mathrm{mL}$ and MIC $($ YMR307W $)=0.40 \mu \mathrm{g} / \mathrm{mL}($ Table 2)

As noted before, the cell wall mutant YMR307W is defective in the gene encoding a $\beta$-1,3-glucanosyltransferase (GAS1) which is involved in the cross linkage and incorporation of $\beta$-1,3-glucan into the cell wall (Ram et al., 1998; Mouyna et al., 2000). Deletion of GAS1 results in several morphologic defects; cells are round and larger with higher percentage of budded and multiple budded cells forming clumps that are difficult to disperse, suggesting that the separation of the bud from mother 
cell has been affected (Popolo et al., 1993). In addition to morphologic defects, GAS1 mutants have lower $\beta$-glucan content in the cell wall despite an increased $\beta$-1,3-glucan synthase activity. This is probably the result of a defective incorporation of $\beta$-1,3-glucan into the cell wall, which is reported to be released into the media (Ram et al., 1998). Furthermore, an increase in mannoprotein levels and a 10 -fold increase in cell wall chitin were observed in GASl mutants (Popolo et al., 1997). Hence it is possible that in an attempt to ensure cell wall integrity, the YMR307W mutant compensates for the defective $\beta$-1,3-glucan assembly and the resulting loss of cell wall strength by upregulation the cell wall integrity pathway (CWI) and reinforcing the cell wall with chitin (Klis, et al., 2006). Therefore, it can be reasoned that the decreased sensitivity of the YMR307W mutant to caspofugin relative to the wild type S288C is the result to some extent of the adaptation of this YMR307W mutant to a defective incorporation of $\beta$-1,3-glucan in the cell wall. In any case, YMR307W serves as a strain that is partially resistant to the CWD effects of caspofungin.

\section{Frequency of Evans Blue stained cells (EB+) and loss of viability}

Adding another layer of complexity to the interpretation of the results of the non-sonicated caspofungin treated samples is the fact that casT/-S samples exhibited significantly higher percentage of Evans Blue stained cells (Figure 14) than any of the other non-sonicated samples: $3.9 \%$ in the wild type S288c and 9.58\% in YMR307W mutant compared with the control values of $0.61 \%$ and $1.27 \%$ in the $S 288 \mathrm{c}$ and YMR307W, respectively (Tables 4 and 5). This marked increase in EB staining, especially in the YMR307W mutant, is in conflict with the results of the intra-assay control assay (drop plate method), which assured a growth inhibition of $\sim 40 \%$ for 
the caspofungin treated group as it did for all other treated groups (Figure 10). A plausible explanation lies in the mechanism of the Evans Blue staining assay. Evans Blue has inverse properties of a vital stain; cells with intact cell wall/membrane are able to exclude the stain from the cytoplasm whereas cells with damaged membranes can not exclude the dye from the cytoplasm. Therefore, the quantification of cell viability by the Evans Blue method is based on the assumption that incorporation of the Evans Blue dye into the cytoplasm is an indication that the cell is non-viable and incapable of repair, in other words - dead (Chen et al., 2003; Jimenez et al., 2009). However, quantification of cell viability by the Evans Blue uptake assay is not without its limits. Considering that given time, a cell with a temporarily non-functional cell wall/membrane complex (e.g., overtaxed or temporarily non-functional efflux pump) might be capable of repair if the cell is removed from the environment/agent causing the injury (Crutchfield et al., 1999). The apparent discrepancy between the drop plate assay and the Evans Blue staining may, therefore, reflect cell wall disruption by caspofungin that does not subsequently lead to cell death.

\subsubsection{Test compounds-E. purpurea crude extract}

\section{Echinacea crude extract-a potential cell wall disrupting agent}

Echinacea has a long history of medicinal use by the Native Americans to treat infections and pain in general. The anti-inflammatory, antimicrobial and immunostimulatory properties and chemical composition of Echinacea have been extensively studied (for a review see Bauer, 1999; Miller and Yu, 2004). Previous experiments using gene deletion arrays indicated that yeast cell wall mutants, including the YMR307W strain used in this study, are especially sensitive to growth 
inhibition with exposure to Echinacea extracts (Mir-Rashed et al., 2010). In the present study, we further investigate the effect of mild sonication on yeast cells treated with Echinacea crude extract by direct florescence microscopy observation of cell wall damage.

Percentage of cell wall damage (CWD), frequency

of Evans Blue stained cells and loss of viability $(E B+)$ findings

Our results show that the percentage of CWD in the non-sonicated samples treated with Echinacea (echT/-S) concentrations that result in $40 \%$ growth inhibition were not significantly different from the non-treated controls. This was true for both wild type S288C and YMR307W strains (Figure 14 and Tables 4 and 5). This is a good indication that the cells were not damaged by the treatment with Echinacea at the tested concentration and/or by handling during the assay. Therefore, any increase in CWD observed in the sonicated samples treated with Echinacea $(\operatorname{ech} T /+S)$, in comparison to the non-treated control $(-T /+S)$, is likely due to an effect by Echinacea extract on the cell wall/membrane complex. Of all the compounds tested, sonicated Echinacea-treated samples $(\mathrm{echT} /+\mathrm{S})$ tended to have the highest percentage of cells showing CWD (Figure 15). As shown in Tables 4 and 5, CWD for the wild type S288C and YMR307W echT/ $+S$ strains were $28.7 \%$ and $25.1 \%$ respectively, in contrast with $12.2 \%(\mathrm{~S} 288 \mathrm{C})$ and $11.0 \%(\mathrm{YMR} 307 \mathrm{~W})$ in the $-\mathrm{T} /+\mathrm{S}$ controls.

Similarly, the frequency of Evans Blue stained cells in the non-sonicated Echinacea treated wild type group ( $2288 \mathrm{C}$ echT/-S) did not differ significantly from the non-treated control (-T/-S) (Table 4, Figure 14). A significantly higher percentage of $\mathrm{EB}+$ cells $(2.99 \%)$ were found in the YMR307W mutant echT/-S when compared 
with the $-\mathrm{T} / \mathrm{S}$ control (1.27\%). It should be noted, however, that the YMR307W echT/-S value was not significantly different form the hygT/-S (2.03\%) and nat T/-S (2.18\%) negative controls (Table 5, Figure 14). In contrast to the non-treated controls groups $(-\mathrm{T} / \mathrm{S})$, both strains $\mathrm{S} 288 \mathrm{C}$ and $\mathrm{YMR} 307 \mathrm{~W}$, when treated with Echinacea extract prior sonication $(\mathrm{echT} / \mathrm{S})$, had a significantly greater frequency of Evans Blue stained cells (Tables 4 and 5, Figure 15).

Overall, these results showed that Echinacea treatment does increase the sensitivity of yeast to sonication as based both on increased frequencies of cells with CWD and Evans Blue staining. Thus, the experiments provide support for the hypothesis that Echinacea extracts contain a fungal cell wall disrupting agent (Mir-Rashed et al., 2010). Given that alkamides are major constituents of the Echinacea extracts used in these studies, we next examined whether specific alkamides likewise disrupt the yeast cell wall/membrane complex.

\subsubsection{Test compounds - Synthetic alkamides from Echinacea}

\section{Alkamides, the major lipophilic compounds in Echinacea}

Alkamides are the major lipophilic compounds in Echinacea ethanol extracts and are thought to be the major active ingredient of Echinacea pharmaceutical preparations (Woelkart and Bauer, 2007). In this study, we investigated the effect on the yeast cell wall of seven synthetic alkamides that occur at different concentrations in Echinacea root extracts (Table 3). The seven alkamides tested differ from each other by the length of the carbon chain, the degree of saturation, and position of saturated carbon bonds (Table 1). 


\section{Percentage of cell wall damage (CWD), frequency of Evans Blue stained cells and loss of viability $(E B+)$ findings}

None of the alkamide treated non-sonicated (alkT/-S) samples had significantly higher levels of cell wall damage (CWD) when compared with the non-treated $(-T /-S)$ controls (Figure 14, Tables 4 and 5). In contrast to the non-sonicated samples, treatments with each of the seven alkamides followed by sonication $($ alkT $/+S)$ resulted in a significantly higher level of cell wall damage (CWD) when compared with the non-treated $(-T /+S)$ and negative (hygT/ $+S$ and nat $T /+S)$ controls. This was observed for both wild type S288C and the cell wall mutant YMR307W strains.

The percentage of cell wall damage in sonicated samples showed a clear division of the alkamides into two groups: the alkamides alk2b and alk $3 a$ together with Echinacea (ECH) have the highest activity, followed by the second group comprising the remaining five alkamides, including the "tetraenes". It stands out that alk2b, alk3a and alk5 all have a 8,10 diyne moiety (two triple bonds at 8 and 10 carbon position), in contrast with only double bonds found in the $2,4,8,10$ tetraenes (alk8E and alk8Z), 2,4,8 triene (alk11) and 2,4 diene (alk12) as seen in Table 1 . Also, alk2b differs from alk3a and alk5 by having one extra double bond at position $\mathrm{C} 4$, and alk5 differs from both alk2b and alk3 in having an additional methyl group at the diyne terminal. Of the three alkamides displaying triple bonds, alk $2 b$ and alk $3 a$ were the most effective in inducing cell wall damage in both yeast strains tested. Considering that alk2b, alk3a and alk5 display such similar molecular structure, especially alk3a and alk5, it is surprising to see a statistically lower frequency of cell wall damage associated with the alk5 treatments (Tables 4 and 5). 
Based on these results, it is reasonable to infer that molecular structure variations play an important role in the alkamides cell wall disrupting activity. It appears that a terminal 8,10 diyne moiety enhances the cell wall disrupting capability of alk $2 b$ and alk3a. A similar correlation was reported in a study of permeability of alkamides to Caco-2 cell monolayers-a model for the absorption of drugs by the intestinal barrier-Matthias et al. (2004) found a correlation between the molecular structure variations of alkamides from Echinacea and their permeability to the Caco-2 monolayers. The conclusion was that saturation, and methylation on either terminal of the alkamide molecule cause a decrease in alkamide permeability of the Caco-2 monolayers (Figure 4).

In Figure 15 it is also evident that when compared with the non-treated controls the treatment with alkamides by itself did not cause any significant loss of viability. As for the alkamide-treated and sonicated (alkT/ $+S$ ) wild type S288C samples, the percentages of Evans Blue stained cells were significantly higher those observed for the non-treated $(-T /+S)$ and negative (hygT/ $+S$ and nat $T /+S)$ controls but not significantly different among themselves or in comparison with either Echinacea or caspofungin treated samples (Figure 15). More variation was observed among the alkamide-treated samples in the cell wall mutant YMR307W (ANOVA results-Table 5). Most notable is the overlap occurring among all alkamides, with exception of alk $2 b$ and alk12, and the negative controls (hygT/+S and nat $T /+S$ ). Nonetheless, the frequency of Evans Blue stained cells in all alkamide-treated samples was significantly higher when compared with the non-treated control. Overall, we can infer that treatment with any of the seven alkamides tested, with or without sonication, results in an increase in Evans blue staining, a proxy for cell death. 


\section{S. cerevisiae $\mathbf{S 2 8 8 C}$}

$\begin{array}{lll}\text { TCTR } & \text { ECH } & \text { DALK8E } \\ \text { NAAT } & \text { ALK2b } & \text { GALK8Z } \\ \text { OHYE } & \text { DALK3a } & \text { DALK11 } \\ \text { OCAS } & \text { GALK5 } & \text { GALK12 }\end{array}$

\section{\begin{tabular}{l|l}
$\stackrel{ \pm}{\frac{D}{0}}^{10 \%}$ & S. cerevisiae YMR307W
\end{tabular}}

[CTR ECH JALKE

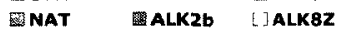

WHYG LALKBa CIALK1

UCAS DALS [BAL12

Figure 14. The figure illustrates the effect of treatment of the yeast cells with the test compounds with no sonication (-)Son. The top panel shows the wild type S288C results and the bottom panel shows the YMR307W cell wall mutant results. Data shows mean percentage $\pm S E$ of cell wall damaged and Evans Blue+ cells without sonication, with and without treatment ( $\mathrm{n} \geq 3000$ cells). Within a group, means linked by the same letter are not significantly different from each other (ANOVA, Tukey test $\alpha=0.05$ ). 

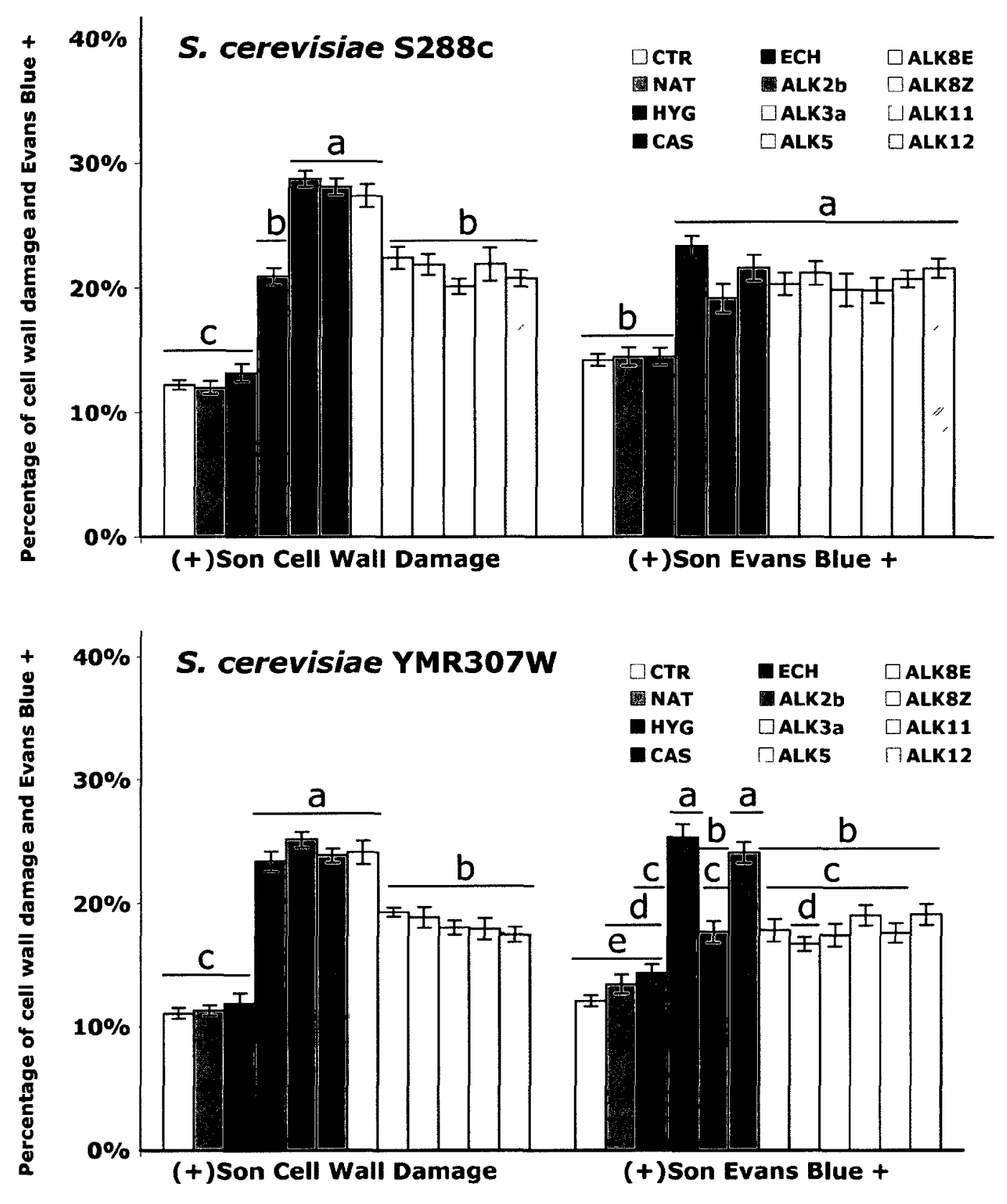

Figure 15. Effect on yeast cells of exposure to test compound followed by mild sonication. The top panel shows the wild type S288C results and the bottom panel shows the cell wall mutant YMR307W results. Data shows mean percentage $\pm S E$ of cell wall damage (CWD) and Evans Blue+ cells in sonicated (+)Son test groups with and without treatment. This data are the results of at least 3 independent experiments were $n \geq 3000$ cells. Within a group, means linked by the same letter are not significantly different from each other (ANOVA, Tukey test $a=0.05 \mathrm{P}<0.0001$ ). 
Table 4. S. cerevisiae wild type $\mathrm{S} 288 \mathrm{C}$ wall damage and cell death measurements. Data show mean percentage $\pm S E$ of cell wall damage (CWD) and Evans Blue stained cells $(\mathrm{EB}+)$ in two main test groups: $(-) S=$ no sonication and $(+) S=$ with sonication, treated with test compounds [cloNAT $=$ Nourseothricin, $\mathrm{HYG}=$ Hygromycin $\mathrm{B}$, $\mathrm{CAS}=$ Caspofungin, $\mathrm{ECH}=$ E.purpurea crude extract and the synthetic alkamides Alk2b,3a,5,8E,8Z,11 and 12 (Table 1)] or without treatment (CTR). Data shown here are the results of at least 3 independent experiments were $n \geq 3000$ cells. Within a group, means designated by the same colored and styled letter are not significantly different from each other (ANOVA, Tukey test $\alpha=0.05$ ).

\begin{tabular}{|c|c|c|c|c|c|c|c|c|c|}
\hline \multirow{3}{*}{$\begin{array}{l}\text { Test } \\
\text { compound }\end{array}$} & \multirow{3}{*}{$\begin{array}{l}\text { Test } \\
\text { group }\end{array}$} & \multirow{3}{*}{\multicolumn{2}{|c|}{$\begin{array}{c}\text { CWD } \\
\% \pm S E\end{array}$}} & \multirow{3}{*}{\multicolumn{2}{|c|}{$\begin{array}{c}\mathrm{EB}+ \\
\% \pm \mathrm{SE}\end{array}$}} & \multicolumn{4}{|c|}{ ANOVA } \\
\hline & & & & & & \multicolumn{2}{|c|}{ CWD } & \multicolumn{2}{|c|}{ EB+ } \\
\hline & & & & & & $(-) S$ & $(+) S$ & $(-) S$ & $(+) S$ \\
\hline \multirow{2}{*}{ CTR } & $(-) S$ & 0.14 & \pm 0.04 & 0.61 & & $\boldsymbol{b}$ & \multirow[b]{2}{*}{ c } & \multirow[t]{2}{*}{ C } & \multirow[b]{2}{*}{ b } \\
\hline & $(+) S$ & 12.2 & \pm 0.39 & 14.2 & \pm 0.48 & & & & \\
\hline \multirow{2}{*}{ cloNAT } & $(-) S$ & 0.00 & \pm 0.00 & 0.51 & \pm 0.15 & $\boldsymbol{b}$ & \multirow[b]{2}{*}{ C } & \multirow[t]{2}{*}{$c$} & \multirow[b]{2}{*}{ b } \\
\hline & $(+) S$ & 12.0 & \pm 0.52 & 14.4 & \pm 0.73 & & & & \\
\hline \multirow{2}{*}{ HYG } & $(-) S$ & 0.02 & \pm 0.02 & 0.52 & \pm 0.12 & $\boldsymbol{b}$ & \multirow[b]{2}{*}{ c } & \multirow[t]{2}{*}{ c } & \multirow[b]{2}{*}{ b } \\
\hline & $(+) S$ & 13.1 & \pm 0.71 & 14.5 & \pm 0.70 & & & & \\
\hline \multirow{2}{*}{ CAS } & $(-) S$ & 0.80 & \pm 0.21 & 3.90 & \pm 0.56 & $a$ & \multirow[b]{2}{*}{$\mathbf{b}$} & \multirow[t]{2}{*}{ a } & \multirow[b]{2}{*}{$\mathbf{a}$} \\
\hline & $(+) S$ & 20.9 & \pm 0.69 & 23.3 & \pm 0.86 & & & & \\
\hline \multirow{2}{*}{$\mathrm{ECH}$} & $(-) S$ & 0.14 & \pm 0.06 & 0.48 & \pm 0.10 & $\boldsymbol{b}$ & \multirow[b]{2}{*}{$\boldsymbol{a}$} & \multirow[t]{2}{*}{ C } & \multirow[b]{2}{*}{$\mathbf{a}$} \\
\hline & $(+) \mathrm{S}$ & 28.7 & \pm 0.63 & 19.2 & \pm 1.16 & & & & \\
\hline \multirow{2}{*}{ Alk2b } & $(-) S$ & 0.30 & \pm 0.15 & 0.82 & \pm 0.19 & $\boldsymbol{b}$ & \multirow[b]{2}{*}{$\mathbf{a}$} & \multirow[t]{2}{*}{$\mathrm{b} / \mathrm{c}$} & \multirow[b]{2}{*}{$\mathbf{a}$} \\
\hline & $(+) S$ & 28.1 & \pm 0.67 & 21.6 & \pm 1.03 & & & & \\
\hline$A 11=3$ & $(-) S$ & 0.03 & \pm 0.03 & 0.51 & \pm 0.20 & $\boldsymbol{b}$ & & C & \\
\hline RukJd & $(+) S$ & 27.4 & \pm 0.91 & 20.3 & \pm 0.88 & & $\mathbf{a}$ & & $\mathbf{a}$ \\
\hline$A l l-6$ & $(-) S$ & 0.04 & \pm 0.04 & 0.79 & \pm 0.16 & $\boldsymbol{b}$ & & $\mathrm{b} / \mathrm{c}$ & \\
\hline Alks & $(+) S$ & 22.4 & \pm 0.88 & 21.2 & \pm 0.93 & & b & & $\mathbf{a}$ \\
\hline Alk 8E & $(-) S$ & 0.10 & \pm 0.05 & 1.29 & \pm 0.29 & $\boldsymbol{b}$ & & $\mathrm{b} / \mathrm{c}$ & \\
\hline & $(+) S$ & 21.9 & \pm 0.86 & 19.8 & \pm 1.30 & & b & & $\mathbf{a}$ \\
\hline 11-07 & $(-) S$ & 0.19 & \pm 0.06 & 0.70 & \pm 0.16 & $\boldsymbol{b}$ & & C & \\
\hline Alk8L & $(+) S$ & 20.1 & \pm 0.60 & 19.8 & \pm 1.01 & & $\mathbf{b}$ & & $\mathbf{a}$ \\
\hline Allb 11 & $(-) S$ & 0.13 & \pm 0.07 & 1.80 & \pm 0.22 & $\boldsymbol{b}$ & & b & \\
\hline Alki1 & $(+) S$ & 21.9 & \pm 1.33 & 20.7 & \pm 0.69 & & b & & $\mathbf{a}$ \\
\hline Alk12 & $(-) S$ & 0.21 & \pm 0.08 & 1.23 & \pm 0.28 & $\boldsymbol{b}$ & & $b / c$ & \\
\hline & $(+) S$ & 20.7 & \pm 0.66 & 21.6 & \pm 0.78 & & b & & $\mathbf{a}$ \\
\hline
\end{tabular}


Table 5. S. cerevisiae cell wall mutant YMR307W cell wall damage and cell death measurements. Data show mean percentage \pm SE of cell wall damage (CWD) and Evans Blue stained cells $(\mathrm{EB}+)$ in two main test groups: $(-) S=$ no sonication and $(+) S=$ with sonication, treated with test compounds [cloNAT= Nourseothricin, $\mathrm{HYG}=$ Hygromycin $\mathrm{B}, \mathrm{CAS}=$ Caspofungin, $\mathrm{ECH}=$ E.purpurea crude extract and the synthetic alkamides Alk2b,3a,5,8E,8Z,11 and 12 (Table 1)] or without treatment (CTR). Data shown here are the results of at least 3 independent experiments were $\mathrm{n} \geq 3000$ cells. Within a group, means designated by the same colored and styled letter are not significantly different from each other (ANOVA, Tukey test $\alpha=0.05$ ).

\begin{tabular}{|c|c|c|c|c|c|c|c|c|c|}
\hline \multirow{3}{*}{$\begin{array}{l}\text { Test } \\
\text { compound }\end{array}$} & \multirow{3}{*}{$\begin{array}{l}\text { Test } \\
\text { group }\end{array}$} & \multirow{3}{*}{\multicolumn{2}{|c|}{$\begin{array}{c}\mathrm{CWD} \\
\% \pm \mathrm{SE}\end{array}$}} & \multirow{3}{*}{\multicolumn{2}{|c|}{$\begin{array}{c}\mathrm{EB}+ \\
\% \pm \mathrm{SE}\end{array}$}} & \multicolumn{4}{|c|}{ ANOVA } \\
\hline & & & & & & \multicolumn{2}{|c|}{ CWD } & \multicolumn{2}{|c|}{ EB+ } \\
\hline & & & & & & $(-) S$ & $(+) S$ & $(-) S$ & $(+) S$ \\
\hline \multirow{2}{*}{ CTR } & $(-) S$ & 0.07 & \pm 0.03 & 1.27 & \pm 0.15 & $a$ & \multirow[b]{2}{*}{ C } & \multirow[t]{2}{*}{ C } & \multirow[b]{2}{*}{ e } \\
\hline & $(+) S$ & 11.0 & \pm 0.43 & 12.1 & \pm 0.45 & & & & \\
\hline \multirow{2}{*}{ cloNAT } & $(-) S$ & 0.09 & \pm 0.05 & 2.18 & \pm 0.33 & $a$ & \multirow[b]{2}{*}{ c } & $\mathrm{b} / \mathrm{c}$ & \multirow[b]{2}{*}{$d / e$} \\
\hline & $(+) S$ & 11.3 & \pm 0.41 & 13.4 & \pm 0.75 & & & & \\
\hline \multirow{2}{*}{ HYG } & $(-) S$ & 0.03 & \pm 0.03 & 2.03 & \pm 0.32 & $\boldsymbol{a}$ & \multirow[b]{2}{*}{ C } & $b / c$ & \multirow[b]{2}{*}{$\mathrm{c} / \mathrm{d} / \mathrm{e}$} \\
\hline & $(+) S$ & 11.8 & \pm 0.83 & 14.3 & \pm 0.76 & & & & \\
\hline \multirow{2}{*}{ CAS } & $(-) S$ & 0.24 & \pm 0.08 & 9.58 & \pm 0.76 & $a$ & \multirow[b]{2}{*}{ a } & $\mathbf{a}$ & \multirow[b]{2}{*}{$\mathbf{a}$} \\
\hline & $(+) S$ & 23.4 & \pm 0.82 & 25.3 & \pm 1.05 & & & & \\
\hline \multirow{2}{*}{$\mathrm{ECH}$} & $(-) S$ & 0.18 & \pm 0.09 & 2.99 & \pm 0.44 & $\boldsymbol{a}$ & \multirow[b]{2}{*}{$\mathbf{a}$} & $b$ & \multirow[b]{2}{*}{$\mathrm{b} / \mathrm{c}$} \\
\hline & $(+) S$ & 25.1 & \pm 0.63 & 17.6 & \pm 0.89 & & & & \\
\hline \multirow{2}{*}{ Alk2b } & $(-) S$ & 0.19 & \pm 0.10 & 2.07 & \pm 0.30 & $a$ & \multirow[b]{2}{*}{$\mathbf{a}$} & $\mathrm{b} / \mathrm{c}$ & \multirow[b]{2}{*}{$\mathbf{a}$} \\
\hline & $(+) S$ & 23.8 & \pm 0.57 & 24.1 & \pm 0.84 & & & & \\
\hline \multirow{2}{*}{ Alk3a } & $(-) S$ & 0.07 & \pm 0.05 & 2.06 & \pm 0.26 & $a$ & \multirow[b]{2}{*}{$\mathbf{a}$} & $\mathrm{b} / \mathrm{c}$ & \multirow[b]{2}{*}{$\mathrm{b} / \mathrm{c}$} \\
\hline & $(+) S$ & 24.1 & \pm 0.93 & 17.8 & \pm 0.92 & & & & \\
\hline \multirow{2}{*}{ Alk5 } & $(-) S$ & 0.04 & \pm 0.03 & 1.37 & \pm 0.17 & $a$ & \multirow[b]{2}{*}{$\mathbf{b}$} & C & \\
\hline & $(+) S$ & 19.3 & \pm 0.38 & 16.7 & \pm 0.58 & & & & $\mathrm{~b} / \mathrm{c} / \mathrm{d}$ \\
\hline Alk8F & $(-) S$ & 0.09 & \pm 0.05 & 1.39 & \pm 0.28 & $a$ & & C & \\
\hline Ang & $(+) S$ & 18.8 & \pm 0.85 & 17.4 & \pm 0.93 & & b & & $\mathrm{b} / \mathrm{c}$ \\
\hline Alk 87 & $(-) S$ & 0.02 & \pm 0.02 & 1.59 & \pm 0.23 & $a$ & & $\mathrm{~b} / \mathrm{c}$ & \\
\hline & $(+) S$ & 18.0 & \pm 0.57 & 19.0 & \pm 0.82 & & b & & b/c \\
\hline Allo1 & $(-) S$ & 0.05 & \pm 0.04 & 1.49 & \pm 0.22 & $a$ & & C & \\
\hline SUKLI & $(+) S$ & 17.9 & \pm 0.86 & 17.6 & \pm 0.81 & & $\mathbf{b}$ & & $b / c$ \\
\hline Alk12 & $(-) S$ & 0.07 & \pm 0.05 & 1.98 & \pm 0.35 & $a$ & & $\mathrm{~b} / \mathrm{c}$ & \\
\hline & $(+) S$ & 17.4 & \pm 0.60 & 19.1 & \pm 0.84 & & $\mathbf{b}$ & & b \\
\hline
\end{tabular}




\subsection{Alkamides quantitative structure-activity relationships (QSAR) \\ Quantitative structure-activity relationships (QSAR) studies of the inhibition of growth of S. cerevisiae by alkamides from Echinacea}

Quantitative structure-activity relationships (QSAR) models are theoretical models that correlate the chemical structure and related physicochemical properties of a molecule to an in vitro or in vivo biological activity. The development of a QSAR model requires a data set of experimental measures of a biological activity for a group of structural analog compounds; one or more physicochemical property descriptors and statistical methods, to find the correlation between these two data sets. Once expressed as a mathematical equation, a QSAR model can be used to predict the efficacy of structurally related compounds in eliciting a biological activity. The information learned from these correlation models can then be used to tailor the chemical structure of a compound to produce more effective analog compounds.

\subsubsection{QSAR non-linear relationships and optimum $\log P\left(\log P_{0}\right)$}

Hansch and Clayton (1973), showed that the relationship between the lipophilicity of compounds $(\log \mathrm{P})$ and biological activities such as inhibition of growth are not linear as the biologic activity can not be infinitely increased by increasing the lipophilicity of a initial structure. In fact, after a certain point an increase in lipophilicity leads to a decrease in the biologic activity (Hansch, 1980) and more often than not these relationships are better represented by a parabolic equation. These observations led to the postulation of the parabolic model equation formally expressed as: 


$$
\log 1 / C=a(\log \mathrm{P})^{2}+b(\log \mathrm{P})+c
$$

Where $\log \mathrm{P}$ is the value of the lipophilicity descriptor for each molecule in the series and where each letter $a, b$ and $c$, represents a coefficient calculated by fitting variations in the data by regression analysis using the least square method.

Hansch findings can be explained by analyzing the journey molecules take from the site of administration to the eventual site of action. Described by Hansch as the "random-walk" process of multiple partition between biological compartments, these interactions are more complex than interactions observed in in-vitro studies and are heavily dependant on the molecules lipophilic character. Along this "randomwalk" process a molecule crosses numerous lipid membranes and partitions in and out of aqueous and lipophilic phases, back and forth until it reaches the target site. The implication of the "random-walk" is that the biologic activity of a compound is a function of its ability to reach and bind to its target site, hence the importance of $\log \mathrm{P}$ as a key determinant of the pharmacokinetic properties of a molecule.

As the $\log \mathrm{P}$ approaches zero and below, hydrophilicity increases to a point that the molecules will not be able to cross lipid membranes and will remain in the first aqueous compartment they encounter never reaching the target site. Conversely, a high $\log \mathrm{P}$ results in such poor aqueous solubility that the compound is sequestered in the first lipid phase it comes across and can not partition out of the lipid to the aqueous cellular and extracellular fluids, thus it may not reach the target site either. Therefore, an intermediate, optimum $\log \mathrm{P}\left(\log \mathrm{P}_{0}\right)$ is needed to achieve maximum biologic activity. This constant represents the ideal balance between the hydrophiliclipophilic character of the drug so that it can reach the sites of action in the minimum 
time without being severely restricted by the "random-walk" process. Often a $\log \mathrm{P}$ value between $2-4$ is considered desirable for drug formulations (Crowley and Martini, 2004) and a $\log P$ of 5 is considered as the upper limit of desired lipophilicity for orally delivered drugs (Lipinski et al., 2001).

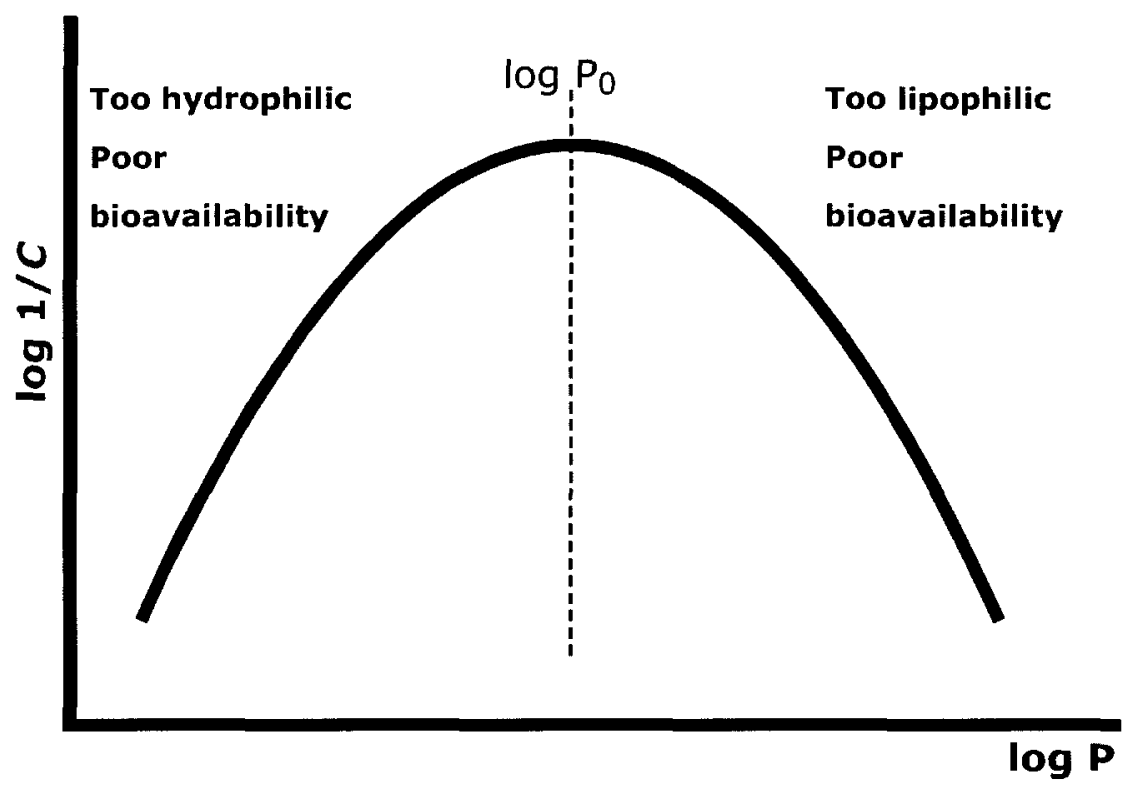

Figure 16. Graphic representation of equation (2b), Hansch's QSAR non-linear relationships between $\log 1 / \mathrm{C}$ and $\log \mathrm{P}$ where the curve is a parabola and optimum $\log P_{0}$ is the apex of the parabola.

\subsubsection{QSAR modeling of the growth inhibitory activity of alkamides}

I used a classic Hansch approach (Hansch and Clayton, 1973) of QSAR modelling to investigate the correlation between the lipophilic properties and the in-vitro antifungal activity of a the seven alkamides from Echinacea listed in Table 1. Briefly, free online tools, Molinspiration Cheminformatics and ALOGPS 2.1, were used to calculate the lipophilicity descriptor log P (octanol-water partition coefficient) 
for each alkamide. In a classic Hansch methodology, the alkamides $\log \mathrm{P}$ values (Table 6) were plotted against the values for the biologic activity measured $(\log 1 / C)$ and subsequently evaluated by regression analysis. In this case, the biologic activity measured $(C)$ is the MIC $40 \%$ expressed in $\mathrm{mol} / \mathrm{L}$ (Table 2). Inverse logarithms for activity are used so that the most effective compounds have higher values in the chart (Figure 17). The curve fitting of the plotted data and statistical analysis of quality of the resulting model was done using GraphPad PRISM version 5, GraphPad Software, San Diego California USA. The resulting QSAR models and statistical quality of the resulting models are discussed next.

\subsubsection{Alkamides QSAR model: Regression analysis and model's goodness-of-fit}

The results of the regression analysis and of the QSAR model's goodnessof-fit for each of the two strains tested, wild type S288C and the cell wall mutant YMR307W are illustrated in Figures 17, 18 and 19. The non-linear regression analysis by the method of least-squares resulted in the equations (3) and (4) below, where $n$ is number of compounds included in the regression; $r^{2}$ is the coefficient of determination and $s$ is the standard deviation.

Model 1-S. cerevisiae wild type S288C:

$$
\begin{gathered}
\log 1 / C_{S 288 C}=0.12(\log P)^{2}-1.22(\log P)+5.97 \\
\left(n=7 ; r^{2}=0.864 ; s=0.041\right)
\end{gathered}
$$

Model 2-S. cerevisiae cell wall mutant YMR307W:

$$
\begin{gathered}
\log 1 / \mathrm{C}_{Y M R 307 W}=0.023(\log \mathrm{P})^{2}-0.47(\log \mathrm{P})+4.8 \\
\left(\mathrm{n}=7 ; \mathrm{r}^{2}=0.730 ; \mathrm{s}=0.092\right)
\end{gathered}
$$


Although both QSAR models follow the same trend, the two regression models varied in terms of goodness-of-fit/coefficient of determination $\left(\mathrm{r}^{2}\right)$. Comparing the two coefficients of determination, it is clear that the wild type strain (S288C) model is the best correlation model of the two. Model 1 has a $\mathbf{r}^{2}$ of 0.86 , which means that $86 \%$ of the total variation in $\mathrm{y}(\log 1 / \mathrm{C})$ can be explained by variation in $\mathrm{x}(\log \mathrm{P})$ as described by equation (3); while in model 2 (YMR307W) $\mathrm{r}^{2}$ is 0.73 , the correlation between $\log 1 / \mathrm{C}$ and $\log \mathrm{P}$ is not as adequately described by the regression model as in the case with model 1 (S288C). This difference can probably be attributed to the limitations of the method used to determined C (MIC40\%), the colony forming unit (CFU) plate counting method (section 3.3.2. Materials and Methods). This technique assumes that each visible colony is derived from an individual cell and that all cells present were recovered during the incubation. However, when applied to a defective mutant with tendency to form aggregates that are difficult to disperse, such is the case of the YMR $307 \mathrm{~W}$ strain, it might result an underestimation of CFUs counts and inaccurate C (MIC 40\%) values that can translate into unreliable QSAR models. Therefore, it is probably wiser to develop QSAR models with the wild type yeast strain that will generate more reliable and more useful models for drug development.

In a second step the QSAR analysis was complemented by the plotting of the experimentally determined $\log 1 / \mathrm{C}$ (observed $\log 1 / \mathrm{C}$ ) versus the $\log 1 / \mathrm{C}$ values predicted by the QSAR model detailed in Equations 3 and 4 (Figure 17, Table 7). The results indicate a good correlation between predicted and observed alkamide antifungal activity for model $1(\mathrm{r} 2=0.92)$, and as expected by the nature of the cell wall mutant strain (YMR307W) discussed above, the correlation between predicted and observed values are not as well described by the regression model as it is in model 1 (S288C). 
Therefore, even though the alkamide set used to develop the QSAR model is small, $\mathrm{n}=7$; it provided QSAR equations that are statistically significant indicating that the models can be applied to predict the antifungal activity of this class of compounds.

\subsubsection{Alkamides drug-likeness-Lipinski's rule of " 5 "}

Besides the fact that the cell wall mutant is notably more sensitive to the antifugal activity of the alkamides, a few other interesting observations regarding the lipophilic nature of the alkamides can be derived from analyzing Figure 17.

The first main observation pertains to the drug-likeness properties of the alkamides as proposed by Lipinski's rule of 5. Developed by Lipinski et al. (2001), this rule-based approach to predict drug-likeness, postulates that poor absorption or permeability are more likely when there are more than " 5 " hydrogen-bond receptors (nitrogen or oxygen atoms with one or more hydrogen atoms-nOHNH), more than "10" hydrogen-bond acceptors (nitrogen or oxygen atoms-nON), the molecular weight (MW) is greater than " 500 " and $\log P$ is greater than " 5 ". All numbers are multiples of 5 , hence the rule of " 5 ". Considering that a desirable characteristic of a drug candidate is good absorption and permeability, the rule states that most "drug-like molecules" have $\log \mathrm{P} \leq 5, \mathrm{MW} \leq 500, \mathrm{nON} \leq 10$ and $\mathrm{nOHNH} \leq 5$. Molecules violating more than one of the rules are more likely to have bioavailability issues and are not good candidates for drug development, conversely the more a compound conforms to the "rule of 5" the higher is the drug-likeness of the compound. The drug-likeness properties of the alkamides used in this study where obtained by entering the molecular structure to a free online tool (JME, 2011) and are summarized in Table 7. The properties of all seven alkamides are well within the rules but one violation was detected as alk 12 has a $\log P$ value that exceeds 5 . 
Table 6. Calculated molecular lipophilicity descriptors (log P) and average $\log P \pm$ standard deviation for the synthetic alkamides used in the present study. Log P values calculated using nine different algorithms (ALOGPS 2.1 calculator).

\begin{tabular}{l|l|l|l|l|l|l|l}
\hline Calculator & Alk2b & Alk3a & Alk5 & Alk8E & Alk8Z & Alk11 & Alk12 \\
\hline ALOGPs & 3.70 & 3.87 & 4.66 & 4.80 & 4.80 & 5.06 & 5.69 \\
\hline AC $\log P$ & 3.25 & 3.61 & 4.63 & 4.46 & 4.46 & 4.81 & 5.17 \\
\hline AB/ LogP & 3.58 & 3.79 & 4.68 & 4.83 & 4.83 & 5.04 & 5.25 \\
\hline miLogP & 3.11 & 3.61 & 4.42 & 4.01 & 4.01 & 4.79 & 5.28 \\
\hline ALOGP & 4.28 & 4.72 & 4.67 & 3.98 & 3.98 & 4.43 & 4.87 \\
\hline MLOGP & 3.26 & 3.34 & 3.59 & 3.51 & 3.51 & 3.59 & 4.60 \\
\hline KOWWIN & 3.74 & 3.95 & 4.50 & 4.75 & 4.75 & 4.97 & 5.18 \\
\hline XLOGP2 & 3.43 & 3.87 & 4.47 & 4.75 & 4.75 & 5.09 & 5.61 \\
\hline XLOGP3 & 3.20 & 3.64 & 4.16 & 4.21 & 4.21 & 4.55 & 5.48 \\
\hline Aver $\log P$ & 3.51 & 3.82 & 4.42 & 4.37 & 4.37 & 4.70 & 5.24 \\
& \pm 0.37 & \pm 0.39 & \pm 0.35 & \pm 0.47 & \pm 0.47 & \pm 0.48 & \pm 0.35 \\
\hline
\end{tabular}

Table 7. Alkamides molecular properties and Lipinski's Rule of 5 for $\log P \leq 5$, $M W \leq 500, n O N \leq 10$ and $n O H N H \leq 5$. Red caption indicates a violation of Lipinski's rule of 5 .

Lipinski's Rule of 5 - alkamides molecular properties

\begin{tabular}{c|c|c|c|c|c}
\hline Alkamide & $\log \mathbf{P}$ & MW & nON & nOHNH & Violations \\
\hline alk2b & 3.51 & 229.32 & 2 & 1 & 0 \\
\hline alk3a & 3.82 & 231.34 & 2 & 1 & 0 \\
\hline alk5 & 4.42 & 245.37 & 2 & 1 & 0 \\
\hline alk8E & 4.37 & 247.38 & 2 & 1 & 0 \\
\hline alk8Z & 4.37 & 247.38 & 2 & 1 & 0 \\
\hline alk11 & 4.70 & 249.40 & 2 & 1 & 0 \\
\hline alk12 & 5.24 & 251.41 & 2 & 1 & 1 \\
\hline
\end{tabular}


Table 8. Predicted and experimentally observed $\log 1 / \mathrm{C}$ values and residuals for the alkamides QSAR models described by equations 3 and 4.

\begin{tabular}{|c|c|c|c|c|c|c|}
\hline \multirow[b]{2}{*}{ Alkamide } & \multicolumn{3}{|c|}{ Wild type S288C } & \multicolumn{3}{|c|}{ YMR307W } \\
\hline & $\begin{array}{l}\text { Observed } \\
\log 1 / C\end{array}$ & $\begin{array}{l}\text { Predicted } \\
\log 1 / C\end{array}$ & Residual & \begin{tabular}{|l} 
Observed \\
$\log 1 / C$ \\
\end{tabular} & $\begin{array}{l}\text { Predicted } \\
\log 1 / C\end{array}$ & Residual \\
\hline alk2b & 3.179 & 3.1647 & 0.01426349 & 3.421 & 3.428 & -0.005976338 \\
\hline alk3a & 3.026 & 3.0607 & -0.03479016 & 3.319 & 3.336 & -0.01982629 \\
\hline alk5 & 2.898 & 2.9254 & -0.02748107 & 3.068 & 3.170 & -0.107261 \\
\hline alk8E & 2.978 & 2.9334 & 0.04456105 & 3.296 & 3.184 & 0.1074635 \\
\hline alk8Z & 2.960 & 2.9334 & 0.02656117 & 3.276 & 3.184 & 0.1074635 \\
\hline alk11 & 2.865 & 2.8920 & -0.02706605 & 2.990 & 3.098 & -0.1121112 \\
\hline alk12 & 2.885 & 2.8810 & 0.00395157 & 2.997 & 2.968 & 0.03024787 \\
\hline & \multicolumn{3}{|c|}{$\mathrm{n}=7 \quad \mathrm{r}^{2}=0.923 \quad \mathrm{P}-\mathrm{v}$} & \multicolumn{3}{|c|}{$\mathrm{n}=7 \quad \mathrm{r}^{2}=0.753 \quad$ P-value $=0.0113$} \\
\hline
\end{tabular}
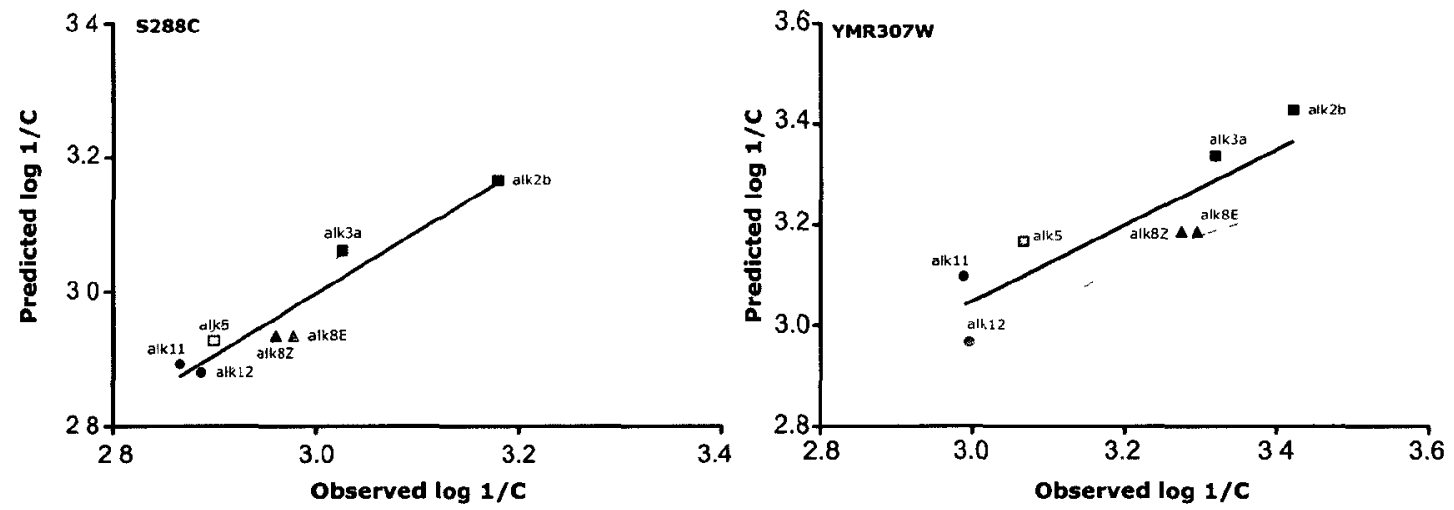

Figure 17. Plots of predicted versus experimentally observed (Table 7) inhibitory activity of synthetic alkamides from Echinacea against S. cereviseae wild type S288C (left panel) and cell wall mutant YMR307W (right panel) strains. Dotted lines represent 95\% confidence intervals. The results showed that the QSAR model for the wild type S288C $\left(r^{2}=0.923\right)$ can be applied to predict antifungal activity of alkamides in the interval calculated. 


\subsubsection{Alkamides optimal $\log P\left(\log P_{0}\right)$ and "cut-off point"}

Still analyzing Figure 17, a second observation can be made in light of the Hansch's QSAR parabola model (Figure 16). Noticeably, all seven alkamides have a $\log \mathrm{P}$ that falls well on the more lipophilic side of the parabola, with the least active alkamides (alk11 and alk12) at the limit of desirable lipophilicity. Ideally, the model should be developed with data points covering the complete parabola, it is probable that a more complete curve could be obtained if more alkamides on the lower spectrum of $\log \mathrm{P}$ were tested. This lack of data points precludes the detection of the optimal $\log P$ and "cut-off point" - a $\log P$ at which biological activity falls off rapidly or disappears completely as the $\log \mathrm{P}$ increases beyond that point in a homologous series. As it is now, without data points in the most hydrophilic side of the parabola, it can not be said conclusively where alk $2 \mathrm{~b}$ is situated with respect to the optimum, we can only conclude that there is a reasonable drop in activity beyond this point, as hydrophobicity increases.

\subsubsection{Alkamides $\log P$ and reported $\log P$ of antifungals and other compounds}

We compared the alkamides $\log \mathrm{P}$ to those reported for antifungals and other classes of compounds (Figure17). As discussed above, clearly the alkamides log $P$ fall on the more lipophilic side of the Hansch's QSAR parabola model, with the most active alkamides (alk2b and alk $3 \mathrm{a}$ ) $\log \mathrm{P}$ values within the considered desirable range for drug formulations (Crowley and Martini, 2004) and the least active alkamides (alk11 and alk12) at the limit of desirable lipophilicity for oral formulations according to Lipinski's rule of 5 (Lipinski et al., 2001). It was also noted that 
a $\log \mathrm{P}$ value between $2-4$ is considered desirable for drug formulations (Crowley and Martini, 2004). Furthermore, a study by Hansch et al. (1968) found that $\log P$ of $\sim 2$ is ideal for drugs acting in the central nervous system (CNS) - This information is crucial for the development of antifungals to treat CNS opportunistic fungal infections, as the ability to cross the blood-brain barrier (BBB) is essential for these class of compounds. In addition, a recent survey of 670,536 combinatorial compounds, 10,968 drugs and 3,287 natural products revealed mean $\log P$ values of $4.3,2.2$ and 2.4 respectively (Vistoli et al., 2008). These results confirm previous findings that for a variety of drugs acting in vivo, log $\mathrm{P}_{0}$ has been found to be $\sim 2$ (Hansch and Lien,1971) and this is a good indication of the bioavailability of natural products compared with combinatorial compounds.

While it is true that a $\log P$ of $\sim 2$ is desirable characteristic for a drug candidate, it should be noted that a large variation of $\log \mathrm{P}$ values is observed in different class of antifungals. For instance, caspofungin-a known fungal cell wall disrupting compound and one of the controls used in this study is watersoluble and has a poor oral bioavailability attributed to a large molecular weight (MW=1093) and low $\log \mathrm{P}$ value of -2.8 , thus caspofungin is administered intravenously. Another example is Amphotericin B (MW=924), which is not water soluble at $\mathrm{pH} 6$ to 7 , but it is soluble in water at $\mathrm{pH} 2$ or 11, however pharmaceutical formulations of Amphotericin B have a $\log \mathrm{P}$ of 0.95 . Triazoles antifungal agents fluconazole $(M W=309)$, voriconazole $(M W=349)$ are poorly water-soluble and have $\log \mathrm{P}$ value of 2.17 and 2.56 respectively while itraconazole $(\mathrm{MW}=705)$ has a $\log \mathrm{P}$ of 6.99. (Kethireddy and Andes, 2007). Griseofulvin (MW=353), a antifungal that inhibits mitosis, has a log P of 2.18 (Hansch and Lien, 1971). 
In view of such variation observed in $\log P$, it is not advisable to directly extrapolate in vitro observations of antimicrobial activity and $\log \mathrm{P}$ relationships to in vivo applications without taking in consideration the complexity of the hydrophilic-lipophilic interactions a molecule endures during the "random-walk" it takes from the site of administration to the eventual site of action. Nevertheless, the $\log \mathrm{P}$-antifungal activity relationship observed for the most active alkamides alk $2 b$ and alk3a, the compliance with Lipinski's "rule of 5" and reported ideal $\log \mathrm{P}$ range of 2-4 for drug formulations (Crowley and Martini, 2004) warrants further investigation of the antifungal activity of this class of compounds.

\subsubsection{Correlation between antimicrobial activity and structural substituentes}

To better understand the role of the various substituents in the lipophilicity and antifungal activity of the alkamide set studied here, the set was divided in two groups based on molecular structure similarities. The alkamides carrying dyienoic moieties are shown in Figure 18a while the dienoic alkamides containing two conjugated double bonds are shown in Figure 18b. The first general observation emerging from analyzing Figure 18 is the fact that the alkamides showing the most antifungal activity (alk2b/3a) have a 11-carbon chain (undeca-) as opposed to the less active remaining alkamides that have a 12 -carbon chain (dodeca-). In a more detailed analysis of the dyienoic group (Figure 18a), consider alk $2 \mathrm{~b}$ as the original analog or parent compound; note how a saturation of the double bond at $\mathrm{C} 4$ results in the alk3a molecular structure, promotes an increase in lipophilicity and a decrease in antifungal activity. Alk3a by its turn results in the alk5 molecular structure when 
a methyl group is introduced in the dyienoic terminal of the carbon chain. This also results in decreased antifungal activity.

Moving on to dienoic alkamides in Figure 18b; it is observed that when compared with alk2b, the substitution of the diynoic moiety for the dienoic moiety in conjunction with the terminal methylation has a highly negative influence on the antifungal activity of these alkamides. This fact seams to indicate that the presence of a diynoic moiety promotes antifungal activity. This is true to a certain point, as it can be deducted by analyzing the antifungal activities of the diynoic moiety carrying alk5 and the dienoic moiety carrying alk8E/Z. That Alk5 has weaker antifungal activity when compared with alk $8 \mathrm{E} / \mathrm{Z}$ can be explained by the lower lipophilicity of alk8E/Z as conferred by its four double-bonds. With regard to alkamides 11 and 12 (Figure 18b), while the relationship lipophilicity/antifungal activity seems to be inverted in this pair, these two differ by only one double bound on $\mathrm{C}-8$, it is more likely that noise in the data is causing the inversion, but without more data points it is difficult to be certain that this is not a real inversion in the curve. 


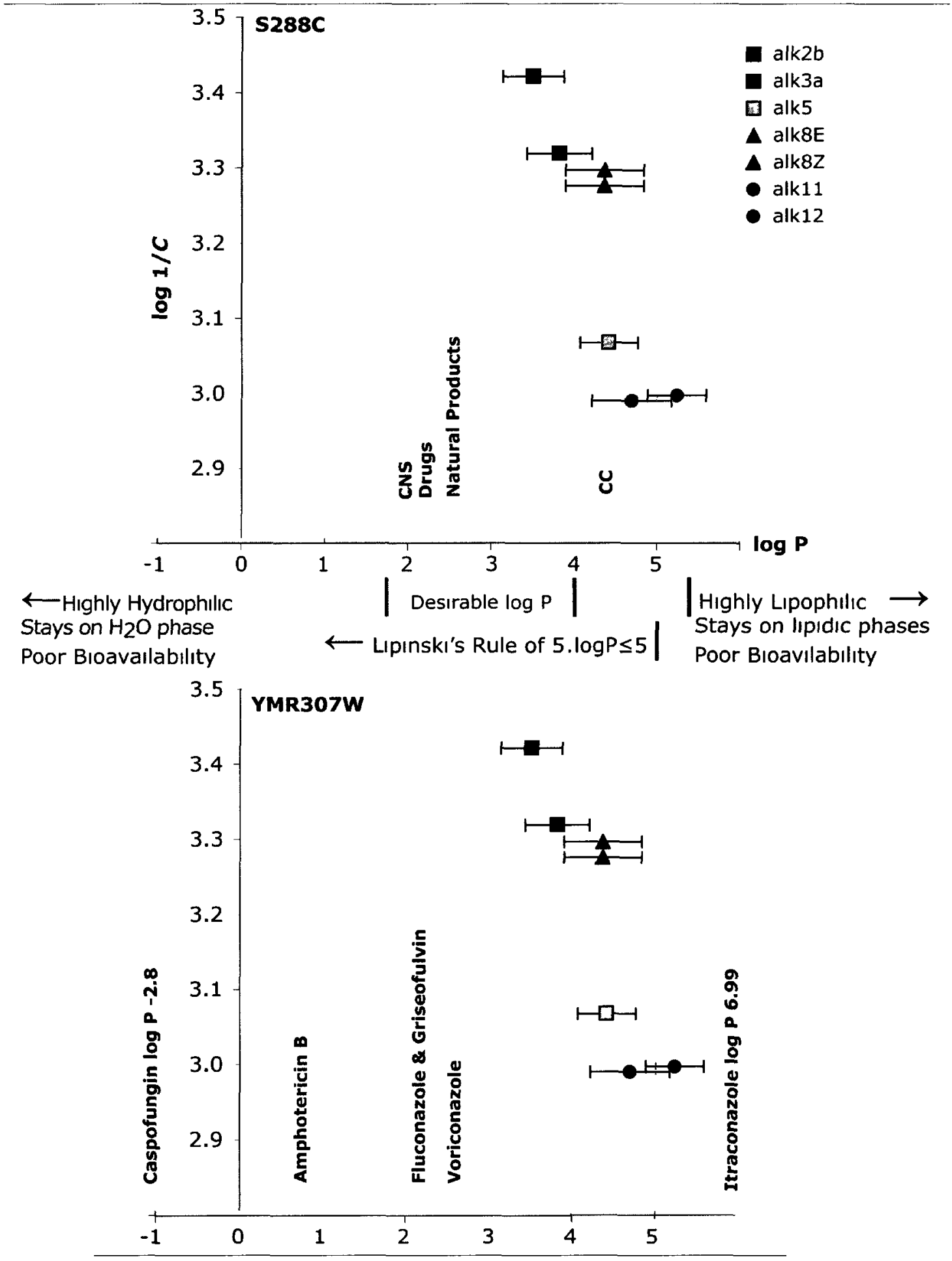

Figure 18. Alkamides $\log \mathrm{P}$ in relation to the reported $\log \mathrm{P}$ of several other compounds. The average $\log P$ of 10,968 Drugs $=2.2 ; 670,536$ Combinatorial Compounds $\mathrm{CC}=4.3 ; 3,287$ Natural Products $=2.4$. CNS=Ideal $\log \mathrm{P}$ for drugs to act in the Central Nervous System. Log P of various antifungals: Caspofungin (-2.8), Amphotericin B(0.95), Fluconazole \& Griseofulvin (2.17 \& 2.18), Voriconazole (2.56) and Itraconazole (6.99). 


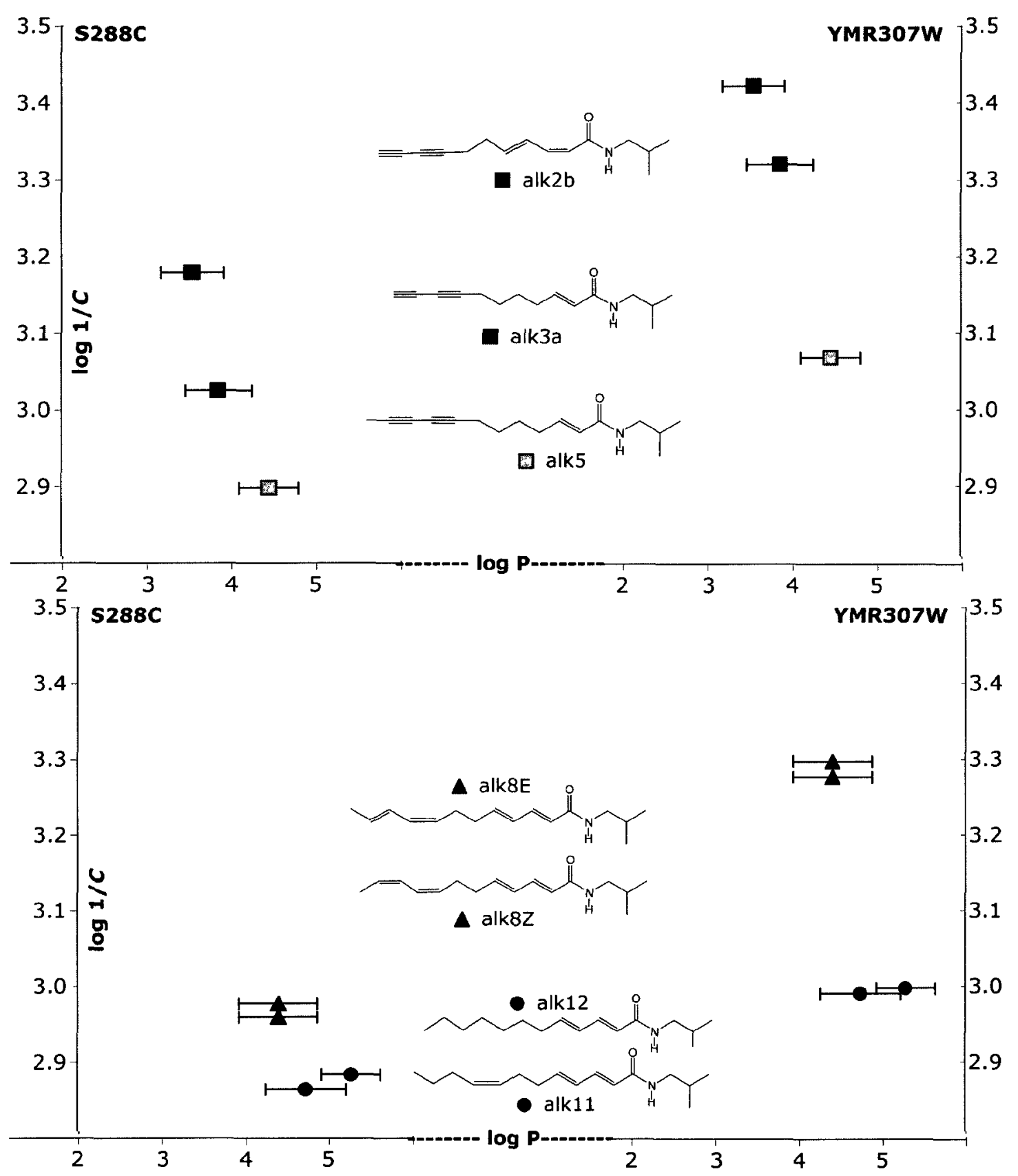

Figure 19. Correlation between the alkamides molecular structure and antifungal activity against $S$. cerevisiae. The two strains are picture side by side to illustrate the increased sensitivity of the cell wall mutant YMR307W to the alkamides. 


\section{Summary and Conclusions}

\subsection{Thesis Summary}

The research presented in this thesis focuses on the study of the potential anti-fungal properties, mode of action and molecular structure-antifungal activity relationship of the alkamides, a large group of closely related unsaturated fatty acid amides widely distributed in plants. Abundant in Echinacea species, most notably in the roots of E. purpurea and E. angustifolia, these secondary metabolites are the major lipophilic compounds in Echinacea extracts. Alkamides are isobutylamides of unsaturated fatty acids and are mostly derived from undeca and dodecanoic acids that differ by the length of the carbon chain, the degree of saturation, and position of saturated carbon bonds (Table 1).

Echinacea itself has a long history of use dating back well beyond the 1700's. Echinacea was used in traditional medicine in a spiritual context by American Natives to heal wounds and treat infections, and quickly adopted by North America settlers in the 1800 's. Echinacea's curative properties were subsequently promoted in a rather "snake-oil salesman" fashion. Reports of Echinacea's healing properties reached Europe and led to its increasing popularity in the 1920's when it was used as an anti-inflammatory and antimicrobial. After the introduction of modern antibiotics, Echinacea and other herbal antimicrobials fell out of use until it was rescued from obscurity by scientific research conducted mostly in Germany in the last 30 years. Today, Echinacea is the fifth top selling herbal medicine in North America grossing $\$ 16$ million in 2009. Presently, Echinacea preparations are used internally to stimulate 
the immune system, to prevent and treat upper respiratory and urinary tract infections, and topically for wound healing.

In vitro and in vivo studies have demonstrated Echinacea's antifungal, antibacterial, antioxidant and anti-virus activity, and ability to modulate the immune cells activity. Efforts to determine the main active principle in Echinacea preparations have been hindered by the complexity of Echinacea's phytochemical composition. The compounds most often recognized for the immuno-modulatory and pharmacological effects of Echinacea are the hydrophilic caffeic acid derivatives, mainly chicoric acid; the lipophilic alkamides and polysaccharides. Yet, if Echinacea's pharmacological activities are caused by a specific compound, a class of compounds or are the result of the many constituents acting synergistically is still a matter of some debate. Nevertheless, new insights concerning membrane permeability, bioavaibility and molecular mode of action, have renewed interest in the hypothesis that alkamides are implicated in the pharmacological effects of Echinacea.

Instigated by these observations and by preliminary results indicating that the antifungal activity of Echinacea is through cell wall disruption by its alkamides, this thesis aimed to further study the antifungal activity and mode of action of Echinacea ethanolic extracts and some alkamides therein. This was accomplished by the development of a fluorescent microscopy assay to detect and quantify yeast cell disruption triggered by exposure to a given compound and amplified by mild sonication (Figure 8). In addition, a general QSAR model was developed to study the molecular structure-antifungal activity relationship of alkamides. The insights obtained from these studies are presented and discussed in Section 4. Results and Discussion, and the conclusions are drawn in the next section. 


\subsection{Conclusions}

\subsubsection{Antifungal activity of test compounds}

\section{Echinacea extract and alkamides have antifungal activity against S. cerevisiae}

The first finding from the results presented in Section 4 was the confirmation of the antifungal activity of Echinacea ethanolic extracts and that of the seven synthetic alkamides studied here. Consequently, it can be inferred that the alkamides in fact contribute to the in vitro antifungal activity of Echinacea against $S$. cerevisiae wild type S288C and the cell wall mutant YMR307W strains. As illustrated in Figure 10, these two yeast strains show similar profiles of growth inhibition in which the cell wall mutant YMR307W is generally more sensitive to inhibition by the tested compounds, except for the test compound caspofungin. The higher sensitivity of the cell wall mutant YMR307W to Echinacea extract and alkamides was somewhat expected since a higher susceptibility of YMR307W to Echinacea extracts was previously reported based on gene deletion array (GDA) analyses with S. cerevisiae viable gene deletion mutants. This previous study identified a group of 23 Echinacea-sensitive mutants with 16 of the mutants having a reported function; from this group a set of 10 gene deletions are reported as being involved in cell wall function, including YMR307W, suggesting that a target for Echinacea is the fungal cell wall (Mir-Rashed et al., 2010). 
The adaptations of the GAS1 mutants to a defective incorporation of $\beta-1,3-$ glucan in the cell wall may explain YMR307W increased resistance to caspofungin

The cell wall mutant YMR307W is reported to have decreased resistance to a series of different class of compounds (SDG project., 2008) including hygromycin B (HYG) that along with nourseothricin (clonNAT) is used as a non-cell wall disrupting antifungal control in my research. Similarly, our results show that when compared to the wild type control S288C, YMR307W is more sensitive to both HYG and clonNAT antifungals. These observations raise the question as why does a cell wall defective yeast strain with decreased resistance to so many compounds show an increased resistance to caspofungin, an antifungal that targets the yeast cell wall by inhibiting the synthesis of a major fungal cell wall component, the $\beta$-1,3-glucan?

As discussed before in Section 4.3.3, the cell wall mutant YMR307W has a deletion of the gene GAS1 that encodes 1,3-beta-glucanosyltransferase, a GPI-anchored protein localized to the extracellular face of the plasma membrane and involved in the remodeling of $\beta$-1,3-glucan after its syntheses by $\beta$-glucan synthase at the membrane (Mouyna et al. 2000). A deletion of GAS1 results in reduced viability and several morphologic defects including cells that are abnormally round and multibudded. This phenotype indicates that GAS1 mutation interferes with the separation of the bud from mother cell (Popolo et al., 1993). Despite an upregulated $\beta$-1,3-glucan synthase activity GAS1 mutants are reported to have lower $\beta$-glucan content in the cell wall as a result of a defective incorporation of $\beta$-1,3-glucan with the excess being 
released into the culture medium (Ram et al., 1998). Furthermore, an increase in mannoprotein levels and a 10-fold increase in cell wall chitin were observed in GAS1 mutants (Popolo et al., 1997). Hence, it is hypothesized that, in an attempt to ensure cell wall integrity, the YMR307W mutant compensates for the defective $\beta$-1,3-glucan assembly and the resulting loss of cell wall strength by upregulating the cell wall integrity pathway (CWI) and reinforcing the cell wall with deposits of chitin (Klis, et al., 2006). Therefore, it can be reasoned that the increased resistance of the YMR307W mutant to the inhibition of $\beta$-1,3-glucan synthesis by caspofugin is the result of the adaptation responses of the YMR307W mutant to a defective incorporation of $\beta$-1,3-glucan in the cell wall.

\subsubsection{Yeast cell wall/membrane complex disrupting activity of test compounds}

The fungal cell wall is a multilayered structure encapsulating the yeast cell. This dynamic interface is essential to sustain the morphology and to protect the yeast cell against adverse environmental conditions. To ensure its biogenesis and integrity at all times a considerable amount of energy and a tightly controlled regulatory apparatus, the cell wall integrity pathway, is necessary. For that, de Groot et al. (2001), estimated that about $20 \%$ of S. cerevisiae genes have a cell wall biogenesis related function. The high demand of the cell wall on the yeast gene machinery and its unique structural and chemical make-up, make the cell wall a desirable target for the development of novel selectively cytotoxic antifungals.

In this thesis, the yeast cell wall disrupting capability of the test compounds is evaluated by detecting and quantifying cell wall damage via a fluorescence microscopy assay. The basis of this assay is the assumption that a weakened yeast 
cell wall/membrane complex will be more sensitive to mild ultrasound-induced cavitation (sonication). Double staining yeast cells suspensions with calcofluor white and Evans Blue makes it possible to observe and enumerate the extent of cell wall damage caused by the treatments with test compounds. Images obtained with duo fluorescence channel DAPI and Rhodamine filters will detect, respectively, calcofluor fluorescence-a blue-white staining the fungal cell walls-and Evans Blue fluorescence which is visualized as a white-reddish/pink fluorescence and indicates loss of metabolic activity in yeast cells. The key steps in this assay are summarized in Figure 8.

\section{Evans blue staining as indicator of cell viability and non-CWD related cell death}

The Evans blue staining was used in this assay as a proxy for dead or non-viable cells that otherwise look intact when observed with the calcofluor white detecting DAPI filter. This staining technique allows the observation of non-CWD related death in the yeast suspensions prior and after sonication (Figure 11). With exception of the caspofungin treated groups, less than $2 \%$ of the yeast cells in the wild type S288C strain and less than 3\% on the cell wall mutant YMR307W were Evans Blue-positive $(\mathrm{EB}+)$ prior sonication, which is a good indication of the general health of the yeast cell suspension and also an indication that the yeast cell have been exposed to a sub-lethal concentration of the test compounds before the sonication treatment. 


\section{Treatment with caspofungin at sub-lethal concentration causes significantly higher frequency of $E B+$ in non-sonicated samples}

Considering the results of the intra-assay control assuring a growth inhibition of $\sim 40 \%$ for the caspofungin treated group (Figure 10, Table 2), the frequency of EB + cells observed in both strains tested was unexpectedly high. Specifically $3.9 \%$ in the wild type S288C and $9.58 \%$ in cell wall mutant YMR307W compared with the controls results of $0.61 \%$ and $1.27 \%$ in the S288c and YMR307W respectively (Tables 4 and 5). The most probable explanation for this finding is the fact that quantification of cell viability by the Evans Blue method is based on the assumption that incorporation of Evans Blue dye into the cytoplasm is an indication that the cell is permanently non-viable and incapable of repair, in other words-dead (Chen et al., 2003; Jimenez et al., 2009). However, it should be considered that, given time, a cell with a temporarily non-functional cell wall/membrane complex (e.g., overtaxed or temporarily non-functional efflux pump) might be capable of repair if the cell is removed from the environment/agent causing the injury (Crutchfield et al., 1999). The apparent discrepancy between the drop plate assay and the Evans Blue staining may, therefore, reflect a cell wall disruption by caspofungin that does not subsequently lead to immediate cell death. 
Mild sonication alone causes some loss of viability, and the combined effect of sonication and treatment with cell wall disrupting compounds causes loss of viability that goes beyond visible cell wall damage

A close examination of the statistics on $\mathrm{EB}+$ cells in the non-treated and sonicated controls $(-\mathrm{T} / \mathrm{S})$ reveals a baseline of $\sim 14 \%$ on $\mathrm{S} 288 \mathrm{C}$ and $\sim 12 \%$ on YMR307W. Therefore any EB+ frequency significantly higher than these baselines can be somewhat related to the combined effects of sonication and prior treatment with test componds.

Frequencies of $\mathrm{EB}+$ in the sonicated samples treated with either aminoglycoside (protein synthesis inhibitor) antibiotics HYG or cloNAT, were not significantly different from that of the non-treated controls. Conversely, all other test compounds treated groups showed a significantly higher frequency of EB+. The nature of the disability causing this increase can only be speculated based on the fact that a functional intact membrane is vital to keep Evans blue from staining the cell cytoplasm, therefore EB+ cells are clearly struggling to keep the dye from staining the cytoplasm, which might be an indication of difficulties in the cell wall/membrane complex function(s) caused by the combined effect of sonication and the effect of a prior treatment with the test compounds that have cell wall disrupting activity, since the protein synthesis inhibitor antibiotics HYG or cloNAT did not show increased frequency of EB+. 
The fluorescence microscopy assay has good specificity as demonstrated by its correct identification of negative controls with exception of caspofungin

The results of fluorescence microscopy assay show no statistically significant cell wall damage (CWD) detected in any of the non-sonicated groups with exception of the caspofungin treated wild type S288C group (Figure14). This is a good indication that the cell wall was not damaged by exposure to the test compounds and an increase in CWD frequency in the sonicated samples is likely due to an effect of the test compound on the cell wall/membrane complex. On the other hand, the CWD frequency detected in the caspofungin treated non-sonicated group was $\sim 0.8 \%$. This very small percentage was still singled out as significant by the ANOVA statistical analysis, which is in support of the reported very specific cell wall disrupting activity of caspofungin by inhibition of $\beta-1,3$-glucan synthase. Even at the relatively low concentration used in this study, set to achieve a $\sim 40 \%$ growth inhibition, exclusive treatment with caspofungin without sonication causes significantly more CWD than that observed in any of the other non-sonicated test compound treated groups.

Hygromycin B and nourseothricin are suitable negative controls for this study.

As exemplified in Figure 15, the results also showed a baseline of $\sim 12 \%$ frequency of CWD in both strains control group of non-treated sonicated cells $(-\mathrm{T} /+\mathrm{S})$ Likewise, both aminoglycoside (protein synthesis inhibitor) antibiotics HYG and cloNAT test results show a CWD frequency very close to the baseline detected for the $(-T /+S)$ control groups and were not singled out as statistically significant by the ANOVA analysis. This indicates that exposures to either HYG or cloNAT, with 
or without sonication, does not cause higher frequency of cell wall damage than that observed in the non-treated controls. This observation validates the use of these compounds as suitable negative controls for this study as they both inhibit yeast proliferation but, under the experimental conditions here, neither is associated with altered cell wall sensitivity to sonication.

\section{Exposure to caspofungin, a $\beta-1,3-$ glucan synthase inhibitor and} cell wall disrupter, results in enhanced sensitivity to sonication.

As expected from a $\beta$-1,3-glucan synthase inhibitor compound, the percentage of cell wall damage in the caspofungin treated prior sonication $(\operatorname{cas} \mathrm{T} / \mathrm{S})$ group was significantly greater than, and almost double of that observed in the control groups $(-T /+S)$ and this was true for both wild type S288C and cell wall mutant YMR307W strains (Figure 15, Tables 4 and 5). Therefore caspofungin can be considered a suitable positive control for this assay.

\section{Treatment with Echinacea enhances the sensitivity of yeast cells to sonication}

Of all the groups tested the sonicated Echinacea-treated group $(\mathrm{echT} /+\mathrm{S})$ had the highest frequency of cell wall damage (Figure 15, Tables 4 and 5), supporting the hypothesis that Echinacea extracts contain a fungal cell wall disrupting agent (Mir-Rashed et al. 2010). Since alkamides are the major constituents of Echinacea extracts, it is reasonable to speculate that alkamides are involved in the cell wall/membrane complex disruption activity of Echinacea extracts. And that is what we examined next.

$$
-100-
$$




\section{Alkamides are potential cell wall/membrane complex disrupting agents}

Likewise the Echinacea extract and caspofungin, all seven synthetic alkamides showed a significantly higher frequency of cell wall damage (Figure 15) when compared with the non-treated $(-T /+S)$ and negative (hygT/ $+S$ and nat $T /+S$ ) controls. Moreover, the alkamides are clearly divided in two groups, with the more active alkamides, alk2b and alk3a, grouped together with Echinacea $(\mathrm{ECH})$, and a second group comprised of five remaining less active alkamides. This second group includes the most abundant of the alkamides, the pair of isomeres alk8E and alk8Z, the "tetraenes" that account for $\sim 45 \%$ of the total alkamides found in Echinacea.

As for the reasoning behind the higher activity of the less abundant alk $2 \mathrm{~b}$ $(\sim 18 \%$ of total alkamides) and alk3a (less than $1 \%)$ it appears to be related to the molecular structure of these alkamides. It stands out that alk2b, alk3a and alk 5 have a 8,10 diyne moiety at $\mathrm{C} 8$ and $\mathrm{C} 10$ carbon position, in contrast with the double bonds found in the 2,4,8,10 tetraenes (alk8E, alk8Z), 2,4,8 triene (alk11) and 2,4 diene (alk12) (Table 1). Considering that of the three alkamides displaying diyne moieties, alk $2 \mathrm{~b}$ and alk3a were the most effective in inducing cell wall damage in both strains tested, it is intriguing that alk5 differing from alk3a only by an additional methyl group at the diyne terminal displayed such a drop in activity. Based on these observations, it is reasonable to infer that molecular structure variations in the alkamides play a key role in the yeast cell wall damage activity of these compounds. To better understand the causal relationship between these variables a proposed Quantitative Structure Activity Relationship (QSAR) model for the alkamides is discussed next. 


\subsubsection{Alkamides QSAR modeling}

Following the paradigm that similar physicochemical properties cause similar biological activities, the goal of Quantitative Structure Activity Relationships (QSAR) modeling in drug development is to obtain a mathematical expression that best describes the relationship between physicochemical properties and biological activity and predict the biologic activity of a group of similar molecular structures. The information learned from these correlation models can then be used to tailor the chemical structure of a compound to produce more effective analog compounds. The QSAR concept was initiated by Corwin Hansch and his groups in early 1960 s and has evolved since then from 2D to encompass much more complex 3D QSARs and 4D QSARs. In this thesis, a classic Hansch approach to QSAR modeling was used to study the correlation between lipophilic properties of alkamides and the in-vitro antifungal activity. To find this correlation, two data sets of property descriptors and statistical methods where used. As described in detail on section 4.4.2., the data set for the lipophilic properties $(\log \mathrm{P})$ of each alkamide was established utilizing free online tools and the second data set used was the experimental values of antifungal activity $\log 1 / \mathrm{C}$, where $\mathrm{C}$ is the alkamide MIC40\% in mol/L (Table 2). The two sets of data were plotted and QSAR model was developed using a non-linear regression analysis by the method of least-squares. 


\section{The alkamides QSAR model are reliable can be used to predict}

the antifungal activiy of alkamides against S. cerevisiae

The two resulting equations of the alkamides QSAR modeling followed the same trend and described $\sim 86 \%$ of the activity for the 7 alkamides in the wild type S288C group and $~ 73 \%$ in the cell wall mutant YMR307W (equations 3 and $4, r^{2}=0.86$ and 0.73 in that order). A complementary analyses plotting the alkamides predicted and experimental antifungal activity show a good fit with $\mathbf{r}^{2}=0.92$ (S288C) and 0.75 (YMR307W). Ideally, a QSAR model should be developed with data points covering most of the parabola; in our case the lack of experimental data points to the more hydrophilic side of the parabola precludes the detection of the optimal $\log \mathrm{P}$ and "cut-off point" - a $\log \mathrm{P}$ at which biological activity falls off rapidly or ceases completely as the $\log \mathrm{P}$ increases beyond that point in a homologous series of molecules. Therefore it is not possible to say conclusively-even though it looks like that it is the case-that the $\log P$ of alk $2 b$ is the "cut-off point". It can only be concluded that there is a reasonable drop in activity beyond this point. Nonetheless, the coefficients of correlation resulting from the QSAR models developed here indicate that, in particular the model developed for the wild type S288C, can be successfully used to predict alkamides in-vitro antifungal activity against S. cerevisiae.

\section{Six of the seven alkamides conform to the Lipinski's "rule of 5",} and as such can be considered good candidates for drug development.

Another interesting outcome of this study pertains to the analysis of the drug-likeness properties of the alkamides as proposed by Lipinski's "rule of 5 " and described in detail in Section 4.4.4. This rule-based approach predicts that molecules violating more than one of the rules are more likely to have bioavailability issues and 
conversely the more a compound conforms to the "rule of 5 " the higher is the compound drug-likeness and the chance it can be successfully developed into marketable drugs. As shown on Table 7, the properties of all seven alkamides are well within the rules with only one violation detected as alk 12 has a $\log \mathrm{P}$ higher than 5. Therefore it can be said that alkamides are good candidates for drug development.

\section{Lipophilicity plays a significant role on the antifungal activity of alkamides}

Of particular interest to this study were the observations drawn from Figures 18 and 19 (plots of $\log$ P versus $\log 1 / C$ ). Figure 19 clearly illustrates the cell wall mutant YMR307W decreased resistance to the antifungal activity of alkamides when compared with the wild type S288C, and in contrast to the activity of caspofungin. This observation could be one more indication of the alkamides potential cell wall/membrane complex disruption activity.

A few other relevant observations can be derived from analyzing Figure 18 and 19. These two figures also illustrate the significant role the lipophilicity parameter has on the antifugal activity of this class of compounds. This was rather expected considering that lipophilicity is also a major factor that influences the pharmacokinetic and pharmacodynamic behavior of molecules when they take the "random-walk" from the site of administration, partitioning in and out of lipophilic membranes and hydrophilic compartments, until it can reach the target site. Noticeably, all seven alkamides have a $\log \mathrm{P}$ positioned on the more lipophilic side of the parabola, with the most active alkamides (alk2b/alk3a) positioned towards the hydrophilic side and the least active alkamides (alk11/alk12) at the limit of desirable lipophilicity, thus 
supporting the concept that there is an optimum $\log \mathrm{P}$ and an ideal balance between lipophilicity and hydrophilicy is required to achieve maximum biologic activity.

\section{Alkamides $\log P$ are comparable to average $\log P$ of other drugs}

Still analyzing Figure 18 , it is interesting to observe how the alkamides $\log \mathrm{P}$ values compare to the $\log \mathrm{P}$ of other antifungals and other classes of compounds reported by other studies (Figure 18). In general, a $\log \mathrm{P} \sim 2$ is considered a desirable value for a good drug candidate. While this may be true, a wide range of $\log \mathrm{P}$ values can be observed in pharmacologically active compounds according to mode of administration and site of action. The antifungal griseofulvin has a $\log \mathrm{P}$ of 2.18 , the triazoles antifungals fluconazole and voriconazole have a $\log \mathrm{P}$ of 2.17 and 2.56 in that order. In contrast, caspofungin has a $\log \mathrm{P}$ of -2.8 and poor bioavailability due a high molecular weight $(\mathrm{MW}=1093)$, therefore it is administered intravenously. On the other side of the spectrum is itraconazole with a $\log \mathrm{P}$ of 6.99 . In the case of the alkamides studied here, the most active alk $2 \mathrm{~b}$ and alk $3 \mathrm{a}$ are well positioned within the range of lipophilicity found in a study of 670,536 combinatorial compounds, 10,968 drugs and 3,287 natural products that found these compounds to have an average $\log \mathrm{P}$ of 4.3, 2.2 and 2.4 respectively (Vistoli et al.,2008). These observations reinforce the argument that alkamides should be granted the status of good antifungal drug candidates that could be used as leads for further drug development. 


\subsubsection{Correlation between antimicrobial activity and structural substituents}

An important issue investigated in this thesis is the role of the various substituents in the lipophilicity and consequently in the antifungal activity of the alkamide set studied. The experimental MICs showed that the alkamides alk2b and alk3a were the most active and QSAR study reveled that these two have $\log \mathrm{P}$ in a range desirable for oral delivery drugs. To better understand how the various substituents are implicated in the antifungal activity of the alkamides, the set was divided in two groups based on molecular structure similarities as displayed in Figure 19. Alkamides carrying dyienoic moieties are shown in Figure 19a and dienoic alkamides are shown in Figure $19 \mathrm{~b}$.

A general observation emerging from the analysis of Figure 19, is that the alkamides showing the most antifungal activity (alk2b/3a) have a 11-carbon chain (undeca-) as opposed to the less active remaining five alkamides that have a 12-carbon chain (dodeca-). This is a first indication that the simple addition of a methyl group can greatly interfere with the antifungal activity of these compounds.

For the sake of argument, and assuming that alk $2 \mathrm{~b}$ is the original analog or parent compound, a saturation of the double bond at $\mathrm{C} 4$ results in the alk3a molecular structure. This single modification to the molecular structure of the original analog promotes an increase in lipophilicity and a decrease in antifungal activity. Following the same line of thought, addition of a terminal methyl group to alk3a results in alk5, a modification that results in decreased antifungal activity. Interestingly a study of permeability of alkamides to Caco-2 cell monolayers (Matthias et al.; 2004) — a model for the absorption of pharmaceutically active 
molecules by the intestinal barrier-found a similar correlation between the molecular structure variations of alkamides from Echinacea and their permeability to the Caco-2 monolayers. The conclusion was that saturation, and methylation on either terminal of the alkamide molecule cause a decrease in alkamide permeability of the Caco-2 monolayers.

By the same token, when compared with alk $2 \mathrm{~b}$, the substitution of the diynoic moiety for the dienoic moiety in conjunction with the terminal methylation have a highly negative influence on the antifungal activity of the dienoic alkamides (Figure 19b). This observation indicates that the presence of a diynoic moiety promotes antifungal activity. This is true to a certain point, as it can be deducted by analyzing the antifungal activities of the diynoic moiety carrying alk5, and the dienoic moiety carrying alk8E/Z. In this case, alk8E/Z lower lipophilicity conferred by its four double-bonds promotes the antifungal activity, while the presence of a diynoic moiety on alk5 was not sufficient to overcame the higher lipophilicity conferred by the additional methyl group in the dyienoic terminal and therefore its weaker antifungal activity. It appears that, in the case of the alkamides studied here, the resulting lipophilicity of the molecule is more relevant to the antifungal activity than the kind of molecular substitution that promoted it. Would it be a case of "it doesn't matter how you get there, as long as you get there"? 


\subsection{Final conclusions}

This thesis demonstrates the potential of the fluorescence microscopy assay developed here to be used as screening assay to investigate the ability of naturallyderived compound to disturb the integrity and/or interfere with functions(s) of the yeast cell wall/membrane complex. Such an assay can provide valuable data to advance drug design by facilitating the exploration of the untapped pharmacological potential of lead molecules mined by bio-prospecting and reverse pharmacology/ ethnopharmacology studies. Equally important, the method may lead to the development of naturally-derived novel antifungals that hopefully will reverse the global impact of antimicrobial resistance.

One of objectives of this thesis was to study the antifungal activity of Echinacea extracts and test the hypothesis that the antifungal mode of action of Echinacea extracts is through the disruption of the yeast cell wall by alkamides. In the course of this research study and thesis preparation I have come to realize that, due to the proximity of the cytoplasmic membrane to the cell wall (Figure 1), it is plausible that disruptions of membrane funtion(s) will somewhat affect the cell wall function(s) and vice-versa. Therefore these two cellular structures would be better served if considered as a complex, hence the expression cell wall/membrane complex used here.

The results of the research done here indicate that Echincaea extract and the seven synthetic alkamides tested have antifungal activity in vitro against $S$. cereviseae wild type S288C and the cell wall mutant YMR307W (GAS1). It was noted that Echinacea extract and the alkamides tested are particularly more effective against 
the mutant YMR307W (GAS1) - A mutant whose 1,3-beta-glucan is not correctly incorporated into the cell wall after its synthesis at the membrane site. This finding suggests that these compounds mode of action cause additional stress to the already overtaxed cell wall/membrane complex of this GAS1 mutant. Moreover, yeast cells subjected to sub-lethal concentrations of Echinacea extract and alkamides prior treatment with mild sonication have shown a significantly higher frequency of cell wall damage when compared with the control groups, proving further support to the hypothesis that the antifungal mode of action of Echinacea extracts is by the disruption of the yeast cell wall/membrane complex by the alkamides.

Furthermore, preliminary unpublished studies are underway to investigate if of Echinacea extracts and alkamides have membrane disruptive activity. This study applies a fluorescence microplate based assay to detect leakage in liposomes encapsulating the fluorescence dye carboxyfluorescein caused by exposure of the liposomes to a membrane active compound. An impressive liposome leakage was observed when these liposomes are exposed to Echinacea extracts and to alk2b (data not shown), indicating a robust liposome disruption activity by these compounds. These findings suggest that these compounds could be disrupting the yeast cell wall/membrane complex by acting at the membrane level and causing cell wall damage by interfering with the biogenesis of the cell wall.

In addition to the experimental data, and of particular importance for understanding the difference in activity among the alkamides tested, are the results of the QSAR model developed here. In the process of gathering data to develop the QSAR model it was detected, based on Lipinski's "rule of 5," that alkamides have molecular properties characteristic of drug-like compounds. Noteworthy is the fact 
that the $\log \mathrm{P}-\mathrm{a}$ measure of lipophilicity that affects membrane penetration and permeability - of the two most active alkamides alk2b and alk3a fall in the range of desirable lipophilicity for orally derived drugs while the least active alkamides fall close to the cut off point where $\log \mathrm{P}$ higher than 5; a $\log \mathrm{P}$ value between $2-4$ is considered desirable for drug formulations. Furthermore, the QSAR studies indicate a strong lipophilicity-antifungal activity relationship in the set of alkamides tested and produced a mathematical expression that can use to predict the antifungal activity of these class of molecules.

Understanding the role of lipophilicity as a major factor in the pharmacokinetic and pharmacodynamic behavior of drugs is of paramount importance to choose a successful drug candidate. An optimum hydrophilicity-lipophilicity balance is essential for efficient drug distribution in the different compartments from the site of administration to site of action-the so called "random-walk". This effect can be observed in Figure 19 where it is clear that an optimum $\log \mathrm{P}$ is required to achieve maximum biologic activity and that the antifungal activity of the alkamides diminish greatly as the molecule becomes too lipophilic. It is noteworthy that the "tetraenes" are the most abundant alkamides in Echinacea extract $(\sim 40 \%$ of the total) but showed a relatively weak antifungal activity when compared with the less abundant alk $2 b$ $(\sim 18 \%$ of the total). Looking at Figure 19 , at first glance, one is tempted to suggest that a diynoic moiety promotes antifungal activity in the alkamides, since the two most effective alk $2 b$ and alk3a carry it; while saturation of double bonds and methylation on the terminal of the alkamide molecule hinder the antifungal activity. However, a more thorough analysis reveals that, in the end, it is the lipophilicity of 
the alkamide that matters, rather than the molecular substituent accountable for that lipophilicity.

To sum up, the findings of this research further document the antifungal activity of Echinacea extracts and alkamides from Echinacea as potential yeast cell wall/membrane complex disrupters. Additional unpublished data from underway studies with liposomes encapsulating a fluorescent dye suggest that these compounds could be disrupting the yeast cell wall/membrane complex by acting at the membrane level. With exception of alk12, all alkamides tested were found to have drug-like properties as defined by Lipinki's "rule of 5". The degree of lipophilicity of the alkamides $(\log P)$ was found to be a key factor in determining the antifungal activity of the alkamides and the subsequently developed QSAR model may be used to predict, to a certain degree, the antifungal activity of these class of compounds. In particular alk $2 b$, the most effective alkamide, should be granted the status lead molecule and possibly be developed in a good drug candidate. 


\subsection{Future directions}

The outcomes obtained from this research are very encouraging to the study of naturally-derived lead molecules such as alkamides from Echinacea. Suggested future research directions include the examination of additional synthetic alkamides designed based on the knowledge gained here about the molecular structure and lipophiliciy-antifungal activity relationship of these compounds. Likewise, further improvements and standardization of fluorescence microplate based liposome assay aiming to develop high-throughput screening methods and to further explore the potential membrane disruption activity of Echinacea extracts and alkamides are also advised. 


\section{Literature Cited}

Agarwal, A. K., Rogers, P. D., Baerson, S. R., Jacob, M. R., Barker, K. S., Cleary, J. D., Walker, L. A., Nagle, D. G. and Clark, A. M. (2003). Genome-wide expression profiling of the response to polyene, pyrimidine, azole, and echinocandin antifungal agents in Saccharomyces cerevisiae. J Biol Chem 278(37): 34998-5015.

Aguilar-Uscanga, B. and Francois, J. M. (2003). A study of the yeast cell wall composition and structure in response to growth conditions and mode of cultivation. Lett Appl Microbiol 37(3): 268-74.

Aronchick, J. M. (2000). Pulmonary infections in cancer and bone marrow transplant patients. Semin Roentgenol 35(2): 140-51.

Baba, M. and Osumi, M. (1987). Transmission and scanning electron microscopic examination of intracellular organelles in freeze-substituted Kloeckera and Saccharomyces cerevisiae Yeast Cells. Journal of Electron Microscopy Technique 5(3): 249-261.

Balandrin, M. F., Kinghorn, A. D. and Farnsworth, N. R. (1993). Plant-Derived Natural Products in Drug Discovery and Development. Human Medicinal Agents from Plants, American Chemical Society. 534: 2-12.

Barnes, J., Anderson, L. A., Gibbons, S. and Phillipson, J. D. (2005). Echinacea species (Echinacea angustifolia (DC.) Hell., Echinacea pallida (Nutt.) Nutt.,Echinacea purpurea (L.) Moench): a review of their chemistry, pharmacology and clinical properties. J Pharm Pharmacol 57(8): 929-54.

Barnes, P. M., Bloom, B. and Nahin, R. L. Complimentary and alternative medicine use among adults and children: United States, 2007. Series. no 12, Hyattsville, MD: National Center for Health Statistics, 2008.

Barrett, B. (2003). Medicinal properties of Echinacea: A critical review. Phytomedicine 10: $66-86$.

Bauer, A. (1999). Chemistry, analysis and immunological investigations of Echinacea phytopharmaceuticals. Immunomodulatory agents from plants. H. Wagner. Basel, Switzerland, Birkhauser Verlag: 41-88. 
Bauer, R., Khan, I. A. and Wagner, H. (1988a). TLC and HPLC analysis of Echinacea pallida and $E$ angustifolia roots. Planta Med 54(5): 426-30.

Bauer, R., Remiger, P. and Wagner, H. (1988b). Alkamıdes from the roots of Echinacea purpurea. Phytochemistry 27(7): 2339-2342.

Bauer, R., Remıger, P. and Wagner, H. (1988c). New Alkamıdes from Echinacea angustıfolıa and E. purpurea Roots. Planta Med 54(6) $563-4$

Bauer, R. and Remiger, P. (1989). TLC and HPLC Analysis of Alkamides in Echinacea Drugs1,2. Planta Med 55(4): 367-71.

Bauer, R., Remiger, P. and Wagner, H. (1989). Alkamides from the roots of Echinacea angustlfolia. Phytochemistry 28(2): 505-508.

Bauer, R. (2000). Chemistry, Pharmacology and Clinical applicatıons of Echinacea products. Herbs, Botanicals and Teas. B. D. O. G. Mazza. Lancaster, Basel, Technomic Publishing Company: 45-73.

Bills, G. F., Platas, G., Ez, F. P. and Masurekar, P. (1999). Reclassification of a pneumocandin-producing anamorph, Glarea lozoyensis gen. et sp. nov, previously identıfied as Zalerion arboricola. Mycol. Res. 103(2): 179-192.

Binns, S., Baum, BR. and Arnason, JT (2002). A taxonomic revision of the genus Echinacea (Heliantheae: Asteraceae). Syst Bot 27: 610-632.

Bınns, S. E., Purgina, B., Bergeron, C., Smith, M. L., Ball, L., Baum, B. R. and Arnason, J. T. (2000). Light-mediated antıfungal activity of Echinacea extracts. Planta Med 66(3): 241-4.

Binns, S. E. (2001). The taxonomy, phytochemistry and biological activity of the genus Echinacea (Asteraceae) (Doctoral dissertation, University of Ottawa). Retrieved from http://hdl.handle.net/10393/9293

Bınns, S. E., Livesey, J. F., Arnason, J. T. and Baum, B. R. (2002). Phytochemical variation in Echinacea from roots and flowerheads of wild and cultivated populations. J Agric Food Chem 50(13): 3673-87.

Borchers, A. T., Keen, C. L., Stern, J. S. and Gershwin, M. E. (2000). Inflammation and Native American medicine: the role of botanicals. Am J Clin Nutr 72(2): 339-347. 
Brodersen, D. E., Clemons, W. M., Carter, A. P., Morgan-Warren, R. J., Wimberly, B. T. and Ramakrishnan, V. (2000). The Structural Basis for the Action of the Antibiotics Tetracycline, Pactamycin, and Hygromycin B on the 30S Ribosomal Subunit. Cell 103(7): 1143-1154.

Cabañas, M. J., Vázquez, D. and Modolell, J. (1978). Dual Interference of Hygromycin B with Ribosomal Translocation and with Aminoacyl-tRNA Recognition. European Journal of Biochemistry 87(1): 21-27.

Cabib, E., Roberts, R. and Bowers, B. (1982). Synthesis of the yeast cell wall and its regulation. Annu Rev Biochem 51: 763-93.

Cabib, E., Roh, D. H., Schmidt, M., Crotti, L. B. and Varma, A. (2001). The yeast cell wall and septum as paradigms of cell growth and morphogenesis. J Biol Chem 276(23): 19679-82.

Cavaliere C., R. P., Lynch M.L., Blumenthal M. (2010). Herbal Supplement Sales Rise in All Channels in 2009. HerbalGram 86: 62-65.

Cech, N. B., Kandhi, V., Davis, J. M., Hamilton, A., Eads, D. and Laster, S. M. (2010). Echinacea and its alkylamides: Effects on the influenza A-induced secretion of cytokines, chemokines, and PGE2 from RAW 264.7 macrophage-like cells. International Immunopharmacology 10(10): 1268-1278.

Chen, C. Y., Nace, G. W. and Irwin, P. L. (2003). A 6 x 6 drop plate method for simultaneous colony counting and MPN enumeration of Campylobacter jejuni, Listeria monocytogenes, and Escherichia coli. J Microbiol Methods 55(2): 475-9.

Chicca, A., Raduner, S., Pellati, F., Strompen, T., Altmann, K.-H., Schoop, R. and Gertsch, J. (2009). Synergistic immunomopharmacological effects of $\mathrm{N}$-alkylamides in Echinacea purpurea herbal extracts. International Immunopharmacology 9(7-8): 850-858.

Chiou, C. C., Groll, A. H. and Walsh, T. J. (2000). New drugs and novel targets for treatment of invasive fungal infections in patients with cancer. Oncologist 5(2): 120-35.

Ciccolini, L., Taillandier, P., Wilhem, A. M., Delmas, H. and Strehaiano, P. (1997). Low frequency thermo-ultrasonication of Saccharomyces cerevisiae suspensions: effect of temperature and of ultrasonic power. Chemical Engineering Journal 65(2): 145-149.

Clifford, L. J., Nair, M. G., Rana, J. and Dewitt, D. L. (2002). Bioactivity of alkamides isolated from Echinacea purpurea (L.) Moench. Phytomedicine 9(3): 249-253. 
Cochrane Database of Systematic Reviews 2006. Echinacea for preventing and treating the common cold Issue 1. Art. No.: CD000530. DOI: 10.1002/14651858.CD000530. pub2.

Cowan, M. M. (1999). Plant products as antimicrobial agents. Clin Microbiol Rev 12(4): 564-82.

Crowley, P. J. and Martini, L. G. (2004). Formulation design: new drugs from old. Drug Discovery Today: Therapeutic Strategies 1(4): 537-542.

Crutchfield, A. 1. M., Diller, K. R. and Brand, J. J. (1999). Cryopreservation of Chlamydomonas reinhardtii (Chlorophyta). European Journal of Phycology 34(01): 43-52.

Dalby-Brown, L., Barsett, H., Landbo, A. K., Meyer, A. S. and Molgaard, P. (2005). Synergistic antioxidative effects of alkamides, caffeic acid derivatives, and polysaccharide fractions from Echinacea purpurea on in vitro oxidation of human low-density lipoproteins. J Agric Food Chem 53(24): 9413-23.

Dallies, N., Francois, J. and Paquet, V. (1998). A new method for quantitative determination of polysaccharides in the yeast cell wall. Application to the cell wall defective mutants of Saccharomyces cerevisiae. Yeast 14(14): 1297-306.

de Groot, P. W., Ruiz, C., Vazquez de Aldana, C. R., Duenas, E., Cid, V. J., Del Rey, F., Rodriquez-Pena, J. M., Perez, P., Andel, A., Caubin, J., Arroyo, J., Garcia, J. C., Gil, C., Molina, M., Garcia, L. J., Nombela, C. and Klis, F. M. (2001). A genomic approach for the identification and classification of genes involved in cell wall formation and its regulation in Saccharomyces cerevisiae. Comp Funct Genomics 2(3): 124-42.

de Groot, P. W., Ram, A. F. and Klis, F. M. (2005). Features and functions of covalently linked proteins in fungal cell walls. Fungal Genet Biol 42(8): 657-75.

Debono, M. and Gordee, R. S. (1994). Antibiotics that inhibit fungal cell wall development. Annu Rev Microbiol 48: 471-97.

Dembitsky, V. (2005). Astonishing diversity of natural surfactants: 4. Fatty acid amide glycosides, their analogs and derivatives. Lipids 40(7): 641-660. Denning, D. W. (1997). Echinocandins and pneumocandins--a new antifungal class with a novel mode of action. J Antimicrob Chemother 40(5): 611-4.

Denning, D. W. (2003). Echinocandin antifungal drugs. Lancet 362(9390): 1142-51. 
Devane, W. A., Dysarz, F. A., 3rd, Johnson, M. R., Melvin, L. S. and Howlett, A. C. (1988). Determination and characterization of a cannabinoid receptor in rat brain. Mol Pharmacol 34(S): 605-13.

Devane, W. A., Hanus, L., Breuer, A., Pertwee, R. G., Stevenson, L. A., Griffin, G., Gibson, D., Mandelbaum, A., Etinger, A. and Mechoulam, R. (1992). Isolation and structure of a brain constituent that binds to the cannabinoid receptor. Science $258(5090)$ : 1946-9.

Diggins, F. W. (2000). The discovery of penicillin: so many get it wrong. Biologist (London) 47(3): 115-9.

Dijkgraaf, G. J., Abe, M., Ohya, Y. and Bussey, H. (2002). Mutations in Fkslp affect the cell wall content of beta-1,3-and beta-1,6-glucan in Saccharomyces cerevisiae. Yeast 19(8): 671-90.

Facino, R. M., Carini, M., Aldini, G., Saibene, L., Pietta, P. and Mauri, P. (1995). Echinacoside and caffeoyl conjugates protect collagen from free radical-induced degradation: a potential use of Echinacea extracts in the prevention of skin photodamage. Planta Med 61(6): 510-4.

Felter, H. W., LIoyd, J.U. (1898). King's American Dispensatory. Cincinnati: Ohio valley Co. Retrieved October 15, 2010, from http://www.henriettesherbal.com/eclectic/ kings/echinacea.html

Ficker, C. E., Arnason, J. T., Vindas, P. S., Alvarez, L. P., Akpagana, K., Gbeassor, M., De Souza, C. and Smith, M. L. (2003). Inhibition of human pathogenic fungi by ethnobotanically selected plant extracts. Mycoses 46(1-2): 29-37.

Francois, I. E., Aerts, A. M., Cammue, B. P. and Thevissen, K. (2005). Currently used antimycotics: spectrum, mode of action and resistance occurrence. Curr Drug Targets 6(8): 895-907.

Franquet, T., Gimenez, A. and Hidalgo, A. (2004). Imaging of opportunistic fungal infections in immunocompromised patient. Eur J Radiol 51(2): 130-8.

Fujita, T. and Hansch, C. (1967). Analysis of the structure-activity relationship of the sulfonamide drugs using substituent constants. J Med Chem 10(6): 991-1000. 
Galván, I. J., Mir-Rashed, N., Jessulat, M., Atanya, M., Golshani, A., Durst, T., Petit, P., Amiguet, V., Boekhout, T., Summerbell, R., Cruz, I., Arnason, J. T. and Smith, M. L. (2008). Antifungal and antioxidant activities of the phytomedicine pipsissewa, Chimaphila umbellata. Phytochemistry 69(3): 738-746.

Ghannoum, M. A. and Rice, L. B. (1999). Antifungal agents: mode of action, mechanisms of resistance, and correlation of these mechanisms with bacterial resistance. Clin Microbiol Rev 12(4): 501-17.

Gietz, D. (1996, December 08, 2006). "The Yeast Media Page”. Yeast Trafo Homepage. Retrieved February 02, 2007, from http://home.cc.umanitoba.ca/ gietz/media.html.

Groll, A. H., De Lucca, A. J. and Walsh, T. J. (1998). Emerging targets for the development of novel antifungal therapeutics. Trends Microbiol 6(3): 117-24.

Groll, A. H. and Walsh, T. J. (2001). Uncommon opportunistic fungi: new nosocomial threats. Clin Microbiol Infect 7 Suppl 2: 8-24.

Hall, I. C. and Schwarz, J. (2002). Phytochemicals from Echinacea. Functional Foods, CRC Press. 2: 239-262.

Hansch, C., Steward, A. R., Anderson, S. M. and Bentley, D. (1968). The parabolic dependence of drug action upon lipophilic character as revealed by a study of hypnotics. Journal of Medicinal Chemistry 11(1): 1-11.

Hansch, C. (1969). Quantitative approach to biochemical structure-activity relationships. Accounts of Chemical Research 2(8): 232-239.

Hansch, C. and Lien, E. J. (1971). Structure-activity relations in antifungal agents. A survey. Journal of Medicinal Chemistry 14(8): 653-670.

Hansch, C. and Clayton, J. M. (1973). Lipophilic character and biological activity of drugs II: The parabolic case. Journal of Pharmaceutical Sciences 62(1): 1-21.

Hansch, C. (1980). Use of quantitative structure-activity relationships (QSAR) in drug design (review). Pharmaceutical Chemistry Journal 14(10): 678-691.

Hansch, C. (1981). The physicochemical approach to drug design and discovery (QSAR). Drug Development Research 1(4): 267-309.

Hector, R. F. (1993). Compounds active against cell walls of medically important fungi. Clin Microbiol Rev 6(1): 1-21. 
Hinz, B., Woelkart, K. and Bauer, R. (2007). Alkamides from Echinacea inhibit cyclooxygenase-2 activity in human neuroglioma cells. Biochemical and Biophysical Research Communications 360(2): 441-446.

Howlett, A. C., Breivogel, C. S., Childers, S. R., Deadwyler, S. A., Hampson, R. E. and Porrino, L. J. (2004). Cannabinoid physiology and pharmacology: 30 years of progress. Neuropharmacology 47 Suppl 1: 345-58.

$\mathrm{Hu}, \mathrm{C}$. and Kitts, D. D. (2000). Studies on the antioxidant activity of Echinacea root extract. J Agric Food Chem 48(5): 1466-72.

Jimenez, C., Capasso, J. M., Edelstein, C. L., Rivard, C. J., Lucia, S., Breusegem, S., Berl, T. and Segovia, M. (2009). Different ways to die: cell death modes of the unicellular chlorophyte Dunaliella viridis exposed to various environmental stresses are mediated by the caspase-like activity DEVDase. J Exp Bot 60(3): 815-28.

JME Molecular Editor. Molinspiration molecular processing engine, version 2010.08. 2011, Molinspiration Cheminformatics. Retrieved March 2011, from http://www.molinspiration.com

Kartsonis, N. A., Nielsen, J. and Douglas, C. M. (2003). Caspofungin: the first in a new class of antifungal agents. Drug Resist Updat 6(4): 197-218.

Kethireddy, S. and Andes, D. (2007). CNS pharmacokinetics of antifungal agents. Expert Opin Drug Metab Toxicol 3(4): 573-81.

Kim, H.-O., Durance, T. D., Scaman, C. H. and Kitts, D. D. (2000). Retention of Alkamides in Dried Echinacea purpurea. Journal of Agricultural and Food Chemistry 48(9): 4187-4192.

Kindscher, K. (1989). Ethnobotany of Purple Coneflower (Echinacea angustifolia, Asteraceae) and other Echinacea species. Economic Botany 43(4): 498-507.

Kindscher, K. (2006). The Conservation Status of Echinacea Species. Lawrence, KS. University of Kansas.

Klis, F. M., Mol, P., Hellingwerf, K. and Brul, S. (2002). Dynamics of cell wall structure in Saccharomyces cerevisiae. FEMS Microbiology Reviews 26(3): 239-256.

Klis, F. M., Boorsma, A. and De Groot, P. W. (2006). Cell wall construction in Saccharomyces cerevisiae. Yeast 23(3): 185-202. 
Korenblum, E., von Der Weid, I., Santos, A., Rosado, A., Sebastián, G., Coutinho, C., Magalhães, F., de Paiva, M. and Seldin, L. (2005). Production of antimicrobial substances by Bacillus subtilis LFE-1, B. firmus H2O-1 and B. licheniformis T6-5 isolated from an oil reservoir in Brazil. Journal of Applied Microbiology 98(3): 667-675.

Lesage, G., Sdicu, A. M., Menard, P., Shapiro, J., Hussein, S. and Bussey, H. (2004). Analysis of beta-1,3-glucan assembly in Saccharomyces cerevisiae using a synthetic interaction network and altered sensitivity to caspofungin. Genetics 167(1): 35-49.

Lesage, G., Shapiro, J., Specht, C. A., Sdicu, A. M., Menard, P., Hussein, S., Tong, A. H., Boone, C. and Bussey, H. (2005). An interactional network of genes involved in chitin synthesis in Saccharomyces cerevisiae. BMC Genet 6: 8 .

Lesage, G. and Bussey, H. (2006). Cell wall assembly in Saccharomyces cerevisiae. Microbiol Mol Biol Rev 70(2): 317-43.

Letscher-Bru, V. and Herbrecht, R. (2003). Caspofungin: the first representative of a new antifungal class. J Antimicrob Chemother 51(3): 513-21.

Lipinski, C. A., Lombardo, F., Dominy, B. W. and Feeney, P. J. (2001). Experimental and computational approaches to estimate solubility and permeability in drug discovery and development settings. Advanced Drug Delivery Reviews 46(1-3): 3-26.

Marx, H., Sauer, M., Resina, D., Vai, M., Porro, D., Valero, F., Ferrer, P. and Mattanovich, D. (2006). Cloning, disruption and protein secretory phenotype of the GAS1 homologue of Pichia pastoris. FEMS Microbiol Lett 264(1): 40-7.

Markovich, S., Yekutiel, A., Shalit, I., Shadkchan, Y. and Osherov, N. (2004). Genomic approach to identification of mutations affecting caspofungin susceptibility in Saccharomyces cerevisiae. Antimicrob Agents Chemother 48(10): 3871-6.

Matovic, N., Matthias, A., Gertsch, J., Raduner, S., Bone, K. M., Lehmann, R. P. and Devoss, J. J. (2007). Stereoselective synthesis, natural occurrence and $\mathrm{CB}(2)$ receptor binding affinities of alkylamides from herbal medicines such as Echinacea sp. Org Biomol Chem S(1): 169-74.

Matthias, A., Blanchfield, J. T., Penman, K. G., Toth, I., Lang, C. S., De Voss, J. J. and Lehmann, R. P. (2004). Permeability studies of alkylamides and caffeic acid conjugates from echinacea using a Caco-2 cell monolayer model. J Clin Pharm Ther 29(1): $7-13$. 
Matthias, A., Addison, R. S., Penman, K. G., Dickinson, R. G., Bone, K. M. and Lehmann, R. P. (2005). Echinacea alkamide disposition and pharmacokinetics in humans after tablet ingestion. Life Sci 77(16): 2018-29.

Matthias, A., Banbury, L., Stevenson, L. M., Bone, K. M., Leach, D. N. and Lehmann, R. P. (2007). Alkylamides from echinacea modulate induced immune responses in macrophages. Immunol Invest 36(2): 117-30.

McGaha, S. M. and Champney, W. S. (2007). Hygromycin B Inhibition of Protein Synthesis and Ribosome Biogenesis in Escherichia coli. Antimicrob. Agents Chemother. 51(2): 591-596.

McGregor, R. L. (1968). The taxonomy of the genus Echinacea (Compositae). Univ. Kansas Sci Bul 48: 113-142.

McNeil, Michael M., Nash, Stephanie L., Hajjeh, Rana A., Phelan, Maureen A., Conn, Laura A., Plikaytis, Brian D. and Warnock, David W. (2001). Trends in Mortality Due to Invasive Mycotic Diseases in the United States, 1980-1997. Clinical Infectious Diseases 33(5): 641-647.

Merali, S., Binns, S., Paulin-Levasseur, M., Ficker, C., Smith, M., Baum, B., Brovelli, E. and Arnason, J. T. (2003). Antifungal and anti-inflammatory activity of the genus Echinacea. Pharm Biol 41(6): 412-420.

Miller, M. W., Miller, D. L. and Brayman, A. A. (1996). A review of in vitro bioeffects of inertial ultrasonic cavitation from a mechanistic perspective. Ultrasound Med Biol 22(9): 1131-54.

Miller, S. and Yu, H. (2004). Echinacea: the genus Echinacea. CRC Press.

Minari, A., Husni, R., Avery, R., Longworth, D., DeCamp, M., Bertin, M., Schilz, R., Smedira, N., Haug, M., Mehta, A. and Gordon, S. (2002). The incidence of invasive aspergillosis among solid organ transplant recipients and implications for prophylaxis in lung transplants. Transplant Infectious Disease 4(4): 195-200.

Mir-Rashed, N., Cruz, I., Jessulat, M., Dumontier, M., Chesnais, C., NG, J., Amiguet, V. T., Golshani, A., Arnason, J. T. and Smith, M. L. (2010). Disruption of fungal cell wall by antifungal Echinacea extracts. Medical Mycology 48(7): 949-958.

Mouyna, I., Fontaine, T., Vai, M., Monod, M., Fonzi, W. A., Diaquin, M., Popolo, L., Hartland, R. P. and Latge, J. P. (2000). Glycosylphosphatidylinositol-anchored glucanosyltransferases play an active role in the biosynthesis of the fungal cell wall. J Biol Chem 275(20): 14882-9. 
Muller-Jakic, B., Breu, W., Probstle, A., Redl, K., Greger, H. and Bauer, R. (1994). In vitro inhibition of cyclooxygenase and 5-lipoxygenase by alkamides from Echinacea and Achillea species. Planta Med 60(1): 37-40.

Munro, S., Thomas, K. L. and Abu-Shaar, M. (1993). Molecular characterization of a peripheral receptor for cannabinoids. Nature 365(6441): 61-5.

Newman, D. J. and Cragg, G. M. (2007). Natural Products as Sources of New Drugs over the Last 25 Years. Journal of Natural Products 70(3): 461-477.

Nguyen, T. H., Fleet, G. H. and Rogers, P. L. (1998). Composition of the cell walls of several yeast species. Appl Microbiol Biotechnol 50(2): 206-12.

Odds, F. C. (2003). Antifungal agents: their diversity and increasing sophistication. Mycologist: 1-5.

Onishi, J., Meinz, M., Thompson, J., Curotto, J., Dreikorn, S., Rosenbach, M., Douglas, C., Abruzzo, G., Flattery, A., Kong, L., Cabello, A., Vicente, F., Pelaez, F., Diez, M. T., Martin, I., Bills, G., Giacobbe, R., Dombrowski, A., Schwartz, R., Morris, S., Harris, G., Tsipouras, A., Wilson, K. and Kurtz, M. B. (2000). Discovery of novel antifungal (1,3)-beta-D-glucan synthase inhibitors. Antimicrob Agents Chemother 44(2): 368-77.

Perry, N. B., van Klink, J. W., Burgess, E. J. and Parmenter, G. A. (1997). Alkamide levels in Echinacea purpurea: a rapid analytical method revealing differences among roots, rhizomes, stems, leaves and flowers. Planta Med 63(1): 58-62.

Pfaller, M. A. and Diekema, D. J. (2004). Rare and Emerging Opportunistic Fungal Pathogens: Concern for Resistance beyond Candida albicans and Aspergillus fumigatus. J. Clin. Microbiol. 42(10): 4419-4431.

PhRMA (2007). Drug Discovery and Development. Understanding the R\&D Process. . Washington.PhRMA - The Pharmaceutical Research and Manufacturers of America,. 2007. Print.

Popolo, L., Vai, M., Gatti, E., Porello, S., Bonfante, P., Balestrini, R. and Alberghina, L. (1993). Physiological analysis of mutants indicates involvement of the Saccharomyces cerevisiae GPI-anchored protein gp1 15 in morphogenesis and cell separation. J Bacteriol 175(7): 1879-85. 
Popolo, L., Gilardelli, D., Bonfante, P. and Vai, M. (1997). Increase in chitin as an essential response to defects in assembly of cell wall polymers in the ggpldelta mutant of Saccharomyces cerevisiae. J Bacteriol 179(2): 463-9.

Qu, L., Chen, Y., Wang, X., Scalzo, R. and Davis, J. M. (2005). Patterns of Variation in Alkamides and Cichoric Acid in Roots and Aboveground Parts of Echinacea purpurea (L.) Moench. HortScience 40(5): 1239-1242.

Raduner, S., Majewska, A., Chen, J. Z., Xie, X. Q., Hamon, J., Faller, B., Altmann, K. H. and Gertsch, J. (2006). Alkylamides from Echinacea are a new class of cannabinomimetics. Cannabinoid type 2 receptor-dependent and -independent immunomodulatory effects. J Biol Chem 281(20): 14192-206.

Ram, A. F., Kapteyn, J. C., Montijn, R. C., Caro, L. H., Douwes, J. E., Baginsky, W., Mazur, P., van den Ende, H. and Klis, F. M. (1998). Loss of the plasma membrane-bound protein Gaslp in Saccharomyces cerevisiae results in the release of betal,3-glucan into the medium and induces a compensation mechanism to ensure cell wall integrity. J Bacteriol 180(6): 1418-24.

Rex, J. H., Pfaller, M. A., Rinaldi, M. G., Polak, A. and Galgiani, J. N. (1993). Antifungal susceptibility testing. Clin Microbiol Rev 6(4): 367-81.

Rex, J. H., Pfaller, M. A., Walsh, T. J., Chaturvedi, V., Espinel-Ingroff, A., Ghannoum, M. A., Gosey, L. L., Odds, F. C., Rinaldi, M. G., Sheehan, D. J. and Warnock, D. W. (2001). Antifungal susceptibility testing: practical aspects and current challenges. Clin Microbiol Rev 14(4): 643-58, table of contents.

Richardson, M. D. (2005). Changing patterns and trends in systemic fungal infections. $J$ Antimicrob Chemother 56 Suppl 1: i5-i11.

Rininger, J. A., Kickner, S., Chigurupati, P., McLean, A. and Franck, Z. (2000). Immunopharmacological activity of Echinacea preparations following simulated digestion on murine macrophages and human peripheral blood mononuclear cells. J Leukoc Biol 68(4): 503-10.

Ruiz, C., Cid, V. J., Lussier, M., Molina, M. and Nombela, C. (1999). A large-scale sonication assay for cell wall mutant analysis in yeast. Yeast 15(10B): 1001-8.

Schoop, R., Klein, P., Suter, A. and Johnston, S. L. (2006). Echinacea in the prevention of induced rhinovirus colds: A meta-analysis. Clinical Therapeutics 28(2): 174-183. 
Schwartz, R. E., Giacobbe, R. A., Bland, J. A. and Monaghan, R. L. (1989). L-671,329, a new antifungal agent. I. Fermentation and isolation. J Antibiot (Tokyo) 42(2): 163-7.

SDG project. Saccharomyces Genome Database. 2008, Retrieved August 04, 2008, from http:// db.yeastgenome.org/cgi-bin/locus.pl?locus=YMR307W

Selassie, C. D. (2003). History of Quantitative Structure-Activity Relationships. Burger's Medicinal Chemistry and Drug Discovery, John Wiley \& Sons, Inc.

Shah, S. A., Sander, S., White, C. M., Rinaldi, M. and Coleman, C. I. (2007). Evaluation of echinacea for the prevention and treatment of the common cold: a meta-analysis. Lancet Infect Dis 7(7): 473-80.

Shemluck, M. (1982). Medicinal and other uses of the Compositae by Indians in the United States and Canada. J Ethnopharmacol 5(3): 303-58.

Singh, N. (2001). Trends in the epidemiology of opportunistic fungal infections: predisposing factors and the impact of antimicrobial use practices. Clin Infect Dis 33(10): $1692-6$.

Smits, G. J., van den Ende, H. and Klis, F. M. (2001). Differential regulation of cell wall biogenesis during growth and development in yeast. Microbiology 147(Pt 4): 781-94.

Stephenson, F. (2004). "A Tale of Taxol". Retrieved November 20, 2010, from http://www. rinr.fsu.edu/fall2002/taxol.html:

Stimpel, M., Proksch, A., Wagner, H. and Lohmann-Matthes, M. L. (1984). Macrophage activation and induction of macrophage cytotoxicity by purified polysaccharide fractions from the plant Echinacea purpurea. Infect Immun 46(3): 845-9.

Toselli, F., Matthias, A. and Gillam, E. M. J. (2009). Echinacea metabolism and drug interactions: the case for standardization of a complementary medicine. Life Sci 85(3-4): 97-106.

Towers, G. H. N., Page, J. E. and Hudson, J. B. (1997). Light-mediated biological activities of natural products from plants and fungi. Curr. Org. Chem. 1(4): 395-414.

Trejo, W. H. and Bennett, R. E. (1963). Streptomyces nodosus sp. n., the amphotericin-producing organism. J Bacteriol 85: 436-9.

VCCLAB Virtual Computational Chemistry Laboratory. 2011, Retrieved March 2011, from http://www.vcclab.org 
Vistolı, G., Pedrettı, A. and Testa, B. (2008). Assessıng drug-lıkeness--what are we missıng? Drug Discov Today 13(7-8): 285-94.

Wagner, H., Stuppner, H., Schaffner, W. and Zenk, M. (1988). Immunologically active polysaccharides of Echinacea purpurea cell cultures. Phytochemistry 27(1): 119-126.

Walsh, T. J., Groll, A., Hiemenz, J., Fleming, R., Roilıdes, E. and Anaissie, E. (2004). Infections due to emerging and uncommon medically important fungal pathogens. Clin Microbiol Infect 10 Suppl 1: 48-66.

“WERNER BioAgents”. Retrieved Jan 19, 2011, from http://www.webioage.de.

Wills, R. B. H. and Stuart, D. L. (1999). Alkylamide and cichoric acıd levels in Echinacea purpurea grown in Australia. Food Chemistry 67(4): 385-388.

WHO - World Health Organization, 2002a. Antımıcrobial resistance, Fact sheet \#194. Retrieved September 20 2010, from http://www.who.int/mediacentre/factsheets/ fs194/en/print.html.

WHO - World Health Organızation, 2002b. Use of antımıcrobıals outsıde human medicıne and resultant antimicrobial resistance in humans, Fact sheet \#268. Retrieved September 20 2010, from http://www.who.int/mediacentre/factsheets/fs268/en/.

WHO World Health Organization, 2008. Traditıonal Medicine, Fact sheet \#134. Retrieved November 18 2010, from http://www.who.int/mediacentre/factsheets/fs134/en/ print.html.

Wilson, L. S., Reyes, C. M., Stolpman, M., Speckman, J., Allen, K. and Beney, J. (2002). The Direct Cost and Incidence of Systemic Fungal Infections. Value in Health 5(1): 26-34.

Woelkart, K., Koidl, C., Grısold, A., Gangemı, J. D., Turner, R. B., Marth, E. and Bauer, R. (2005a). Bioavalability and pharmacokınetıcs of alkamides from the roots of Echinacea angusttfolta in humans. J Clin Pharmacol 45(6): 683-689.

Woelkart, K., Xu, W., Peı, Y., Makriyannıs, A., Picone, R. P. and Bauer, R. (2005b). The endocannabinoid system as a target for alkamides from Echinacea angustıfolia roots. Planta Medica 71(8): 701-705.

Woelkart, K. and Bauer, R. (2007). The role of alkamides as an active principle of Echinacea. Planta Medica 73(7): 615-623. 
Woelkart, K., Dittrich, P., Beubler, E., Pinl, F., Schoop, R., Suter, A. and Bauer, R. (2008a). Pharmacokinetics of the main alkamides after administration of three different Echinacea purpurea preparations in humans. Planta Medica 74(6): 651-656.

Woelkart, K., Linde, K. and Bauer, R. (2008b). Echinacea for Preventing and Treating the Common Cold. Planta Med 74: 633-37.

Zlotnik, H., Fernandez, M. P., Bowers, B. and Cabib, E. (1984). Saccharomyces cerevisiae mannoproteins form an external cell wall layer that determines wall porosity. J Bacteriol 159(3): 1018-26.

ZunZun Online Curve Fitting and Surface Fitting Web Site. 2011, Retrieved March 2011, from http://www.zunzun.com 


\section{Appendix A}

\section{General observations of the effect of mild sonication on yeast cell suspensions}

In addition to the cell wall damage results, a sub-lethal effect of mild sonication treatment on the samples in general was observed. These experiments were conducted at the stage in the yeast cell cycle where mother-daughter units (cells with daughtercell buds attached) dominated the culture, $\sim 70 \%$ (Figure 21 ). However, a very high incidence of viable detached single cell units was observed in sonicated samples with mother-daughter units dropping from $\sim 70 \%$ to $\sim 20 \%$ (Figure 21 ). This occurrence is even more noticeable in the YMR307W mutant, for which the abnormal spherical morphology is a clear contrast to the usual ellipsoid shape of S. cerevisiae. In addition, the typical budded cell aggregates characteristic of YMR307W (Popolo et al., 1993; Marx et al., 2006) were apparently dispersed by sonication (Figure 20). The phenomenon is better illustrated in the cell unit type distribution chart shown in Figure 8 that gives cell characteristics before and after sonication. It should be noted that this effect is significant enough to cause interference with results of drop out plate assays that rely on counting colony-forming units (CFU) before and after sonication as means of evalating the sonication effect. The dispersion of the cell aggregates by mild sonication increases the number of CFU to a point that it surpasses the loss of viability caused by the same mild sonication, thus creating a result where more CFUs are present in the sonicated sample than in the non-sonicated control (Figure 22). 

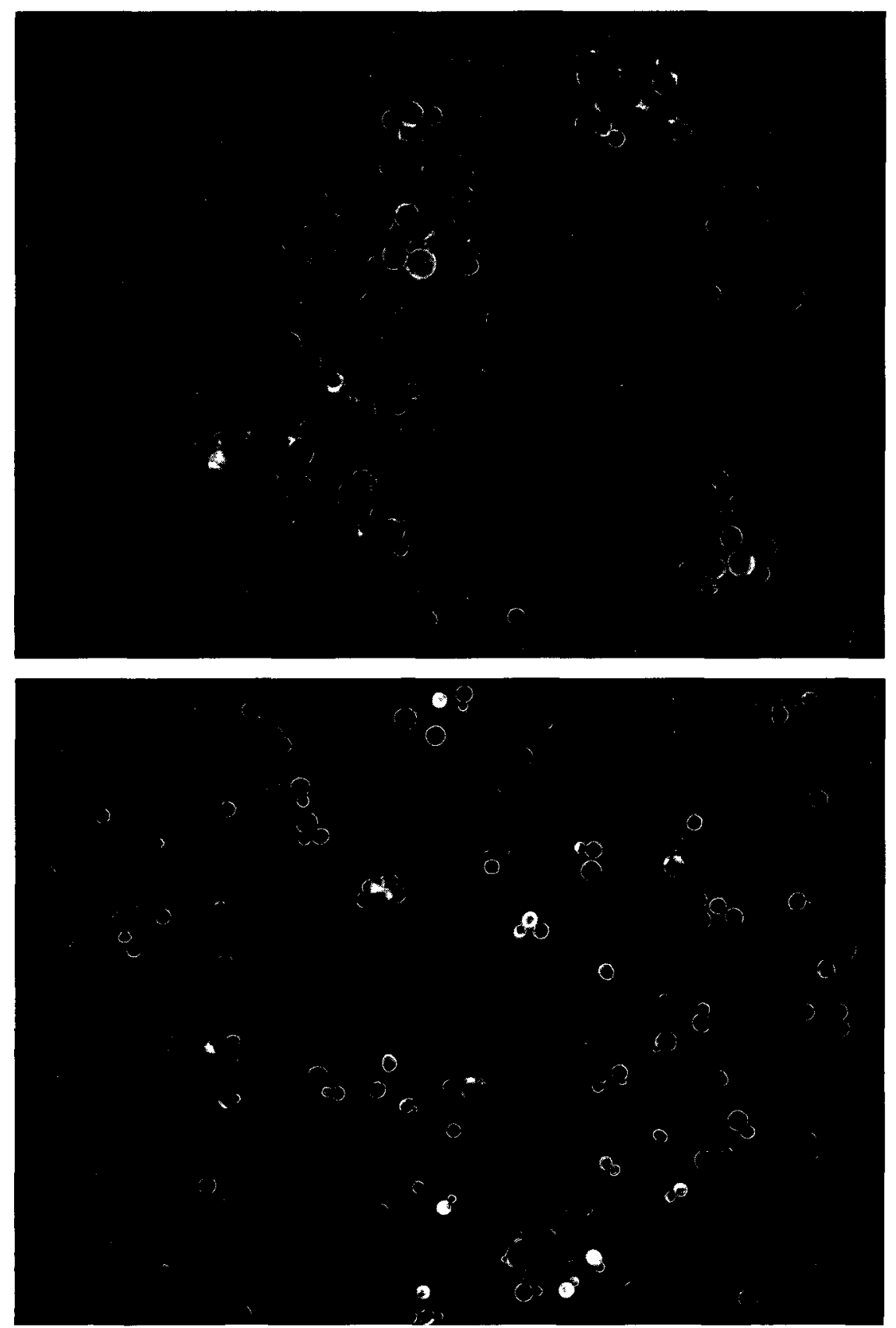

Figure 20. Fluorescence microscopy images of yeast S. cerevisiae YMR307W stained with CFW illustrating the effect of mild sonication in dispersing the typically budded cell aggregates characteristic of this strain (bar $=5 \mu \mathrm{m})$. Top image: Non-sonicated sample. Bottom image: Sonicated sample. 


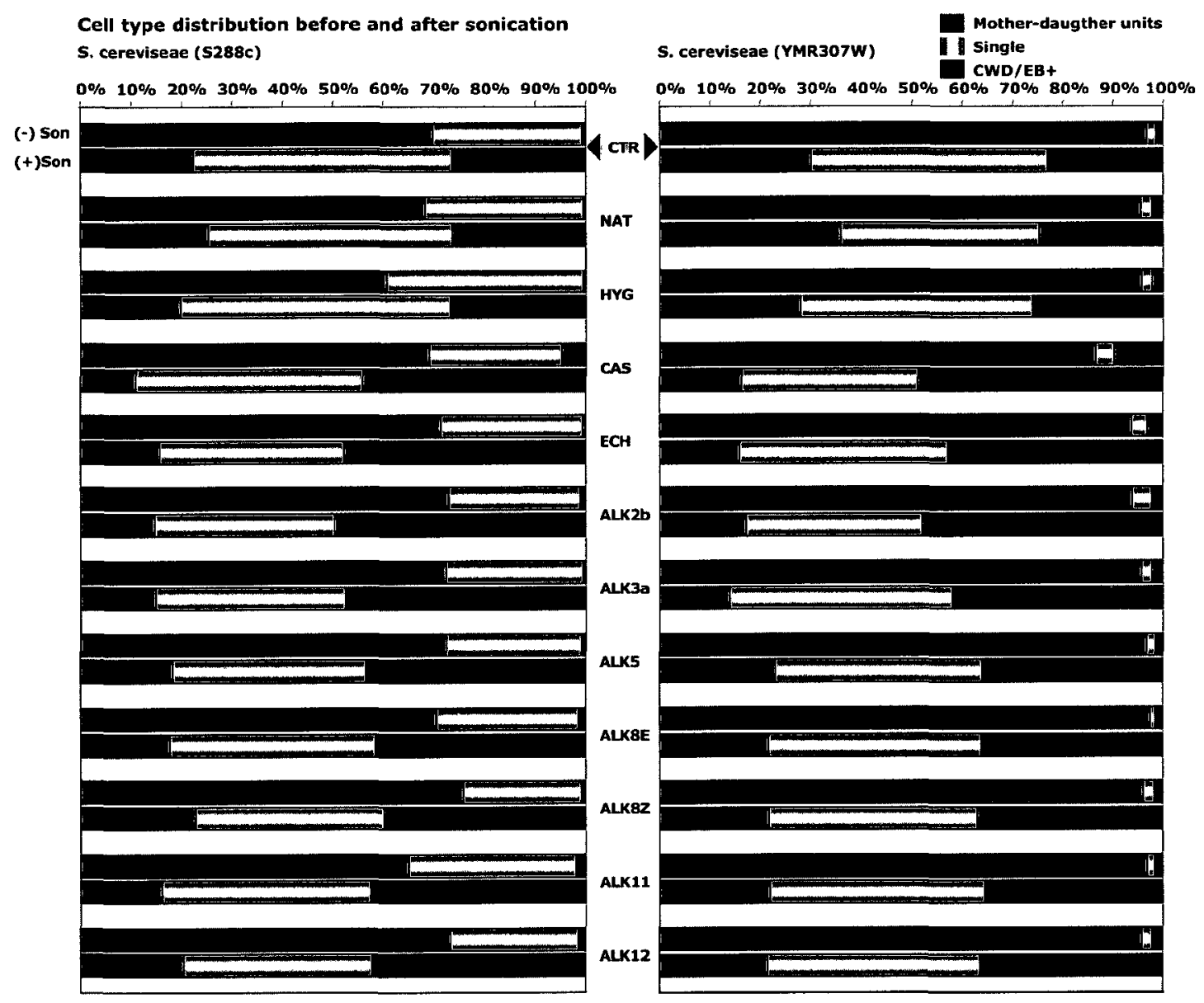

Figure 21. Effect of mild sonication on yeast cell aggregation. Data shows the percentage of Mother-daughter unit, single cells and cell wall damaged/Evans Blue positive in non-sonicated [(-)Son] and sonicated [(+)Son] samples, with and without treatment with each compound tested. Each data set represents the mean value from at least three determinations. The left image shows results for the wild type S288C strain while the right figure show results for the cell wall mutant YMR307W. 


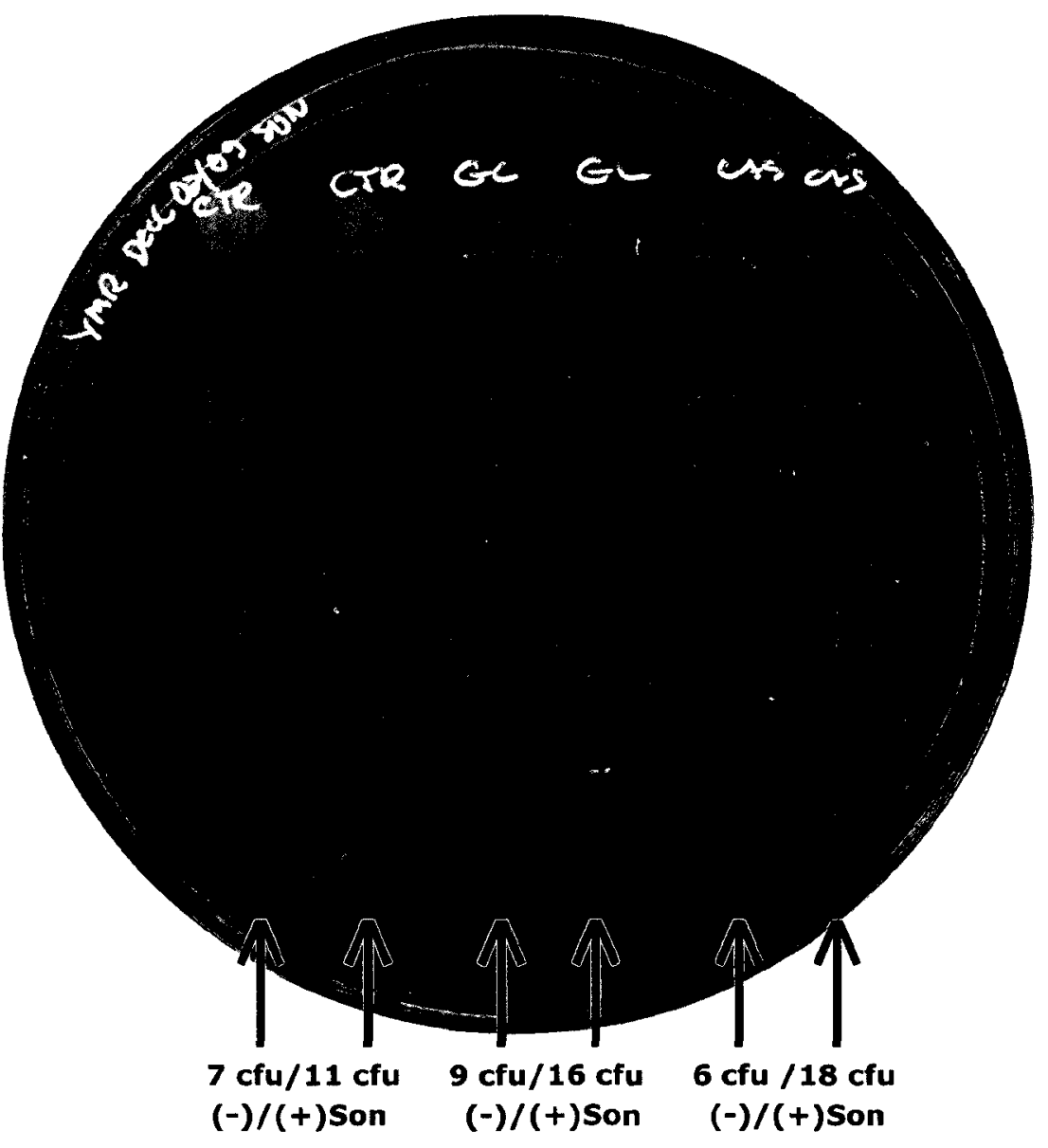

Figure 22. Drop out plate image illustrating how the effect of mild sonication on the cell aggregates typical of YMR $307 \mathrm{~W}$ can create results where more CFUs are present in the sonicated sample than in the non-sonicated control. 